\title{
Private Dispute Resolution in the Card Context: Structure, Reputation, and Incentives
}

Andrew P. Morriss

Texas A\&M University School of Law, amorriss@law.tamu.edu

Jason Korosec

Follow this and additional works at: https://scholarship.law.tamu.edu/facscholar

Part of the Law Commons

\section{Recommended Citation}

Andrew P. Morriss \& Jason Korosec, Private Dispute Resolution in the Card Context: Structure, Reputation, and Incentives, 1 J.L. Econ. \& Pol'y 393 (2005).

Available at: https://scholarship.law.tamu.edu/facscholar/133

This Article is brought to you for free and open access by Texas A\&M Law Scholarship. It has been accepted for inclusion in Faculty Scholarship by an authorized administrator of Texas A\&M Law Scholarship. For more information, please contact aretteen@law.tamu.edu. 


\title{
PRIVATE DISPUTE RESOLUTION IN THE CARD CONTEXT: STRUCTURE, REPUTATION, AND INCENTIVES
}

\author{
Andrew P. Morriss, Ph.D.* \& Jason Korosec, J.D.*
}

\begin{abstract}
Explosive growth in credit, debit, and other card payment systems in recent years has produced a parallel growth in private dispute resolution systems based on the web of contracts entered into by merchants, merchant acquirers, consumers, card issuers, card associations, and transaction processors. These contracts have produced legal systems based on contract and the enforcement of which rests primarily on reputational constraints. To cost-effectively resolve disputes, these private legal systems have evolved innovative procedures using resources at the lowest-possible level, including incentive-payments for producing information and rigid deadlines for parties' actions. This paper describes and analyzes these legal systems and their procedures as a potential model for resolving other categories of disputes.
\end{abstract}

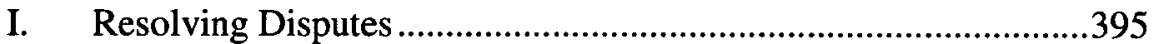

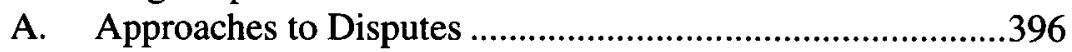

B. Dispute Resolution as a Technology ...................................402

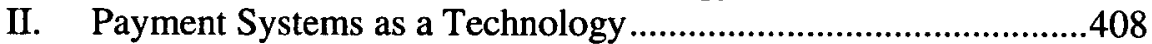

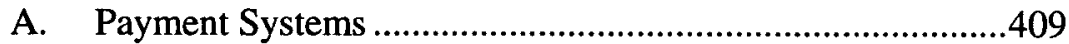

B. The Structure of the Technologies......................................416

1. Similarities Among Card-Based Payment Systems ....416

* Galen J. Roush Professor of Business Law and Regulation \& Director, Center for Business Law and Regulation, Case Western Reserve University and Senior Associate, Property \& Environment Research Center, Bozeman, Montana; A.B. 1981, Princeton; J.D., M. Pub. Aff. 1984, University of Texas at Austin; Ph.D. (Economics) 1994, Massachusetts Institute of Technology. We would like to thank the following: Giancarlo Ibarguen S., Rector, and the Facultad de Derecho of Universidad Francisco Marroquin, Guatemala City, Guatemala, where the hospitality shown us during our visit in the summer of 2004 greatly facilitated work on this paper; Peter Boettke for organizing the project of which this paper is a part and inviting us to participate; seminar participants at a Critical Infrastructure Project seminar at George Mason University, Jonathan Adler, Olufunmilayo Arewa and Roger Meiners for comments; and Dean Gerald Korngold for research support. The views expressed in this paper are our own and do not reflect the views of any of our employers.

** Vice President and Director, Citishare Corporation; Chief Executive Officer, EagleCheck, Ltd.; and Adjunct Associate Professor of Law, Case Western Reserve University School of Law. B.A. 1990, University of Rochester; J.D., M.B.A. 1997 Case Western Reserve University. 
2. Key Differences Among Card-Based Payment Systems ........................................................................424

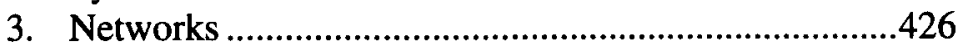

C. Applying the Technology: The Payment Transaction ........430

D. The Private Legal Structure ...............................................435

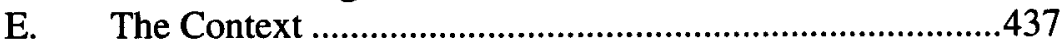

III. Dispute Resolution Systems ......................................................440

A. The Process and Supporting Systems ...................................440

1. Initiating a Dispute ...................................................41

2. Classifying a Dispute ...................................................442

3. Gathering Information from the Cardholder ................443

4. Gathering Information from the Merchant: The Retrieval Request ......................................................445

5. Charging a Transaction Back to the Merchant .............446

6. Representment.........................................................44

7. Acceptance or Rejection of Representment and Further Chargeback Rights...........................................448

8. Association Arbitration and Mediation ..........................448

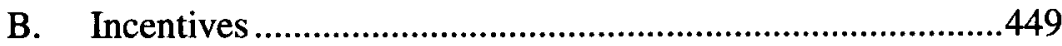

IV. Competition, Regulation, \& the Evolution of the Systems............450

A. The Creation of Card-Based Payment Systems ..................451

B. The Rise of Associations …………………….....................456

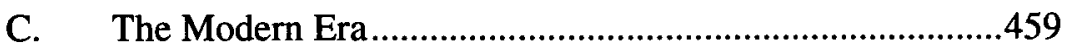

D. Competition-Driven Evolution .............................................461

E. Regulation-Driven Evolution..............................................462

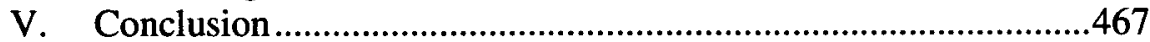

Credit and other payment cards are revolutionizing many aspects of our economy, a revolution that "is arguably more profound than the introduction of paper money." Use of payment cards of various types (charge, credit, and debit) has exploded, with the share of purchases using payment cards growing from 6 percent in 1984 to 32 percent in $2002 .^{2}$ In the year 2000, VISA $^{3}$ alone handled more than $\$ 1.7$ trillion in global transactions. ${ }^{4}$

1 David Evans \& Richard Schmalensee, Paying With Plastic: The Digital Revolution in Buying and Borrowing 25 (1999).

2 Paying with Plastic.org, Stats and Facts, Payment Instruments, http://www .payingwithplastic.org/index.cfm?gesture=statsDetailPrinter\&aid=1312 (last visited February 7, 2005).

3 Note that "VISA" is a used as a short-hand reference to the entire VISA network of organizations (e.g. VISA, USA, VISA Europe, etc.) Where our points depend on reference to a specific VISA entity, we give the precise name.

4 Paul Chutkow, Visa: The Power of an Idea 81 (2001). 
In this paper we explore how card-based payment systems ${ }^{5}$ (e.g. VISA, MasterCard, Discover, American Express) have evolved in response to market and regulatory pressures to include dispute resolution systems, which have largely automated resolution of disputes. These card-based payment systems' dispute resolution procedures use reputational and financial incentives to induce the parties to reveal the information necessary to resolve the disputes. They systematically push dispute resolution procedures to the lowest possible level, and to use procedures that do not require significant investments of time or human capital to resolve the most frequent types of disputes. They also make use of the information generated by disputes to impose constraints which alter behavior to prevent similar disputes in the future involving different parties. These dispute resolution systems solve many of the problems of the public legal system (e.g. high costs, lack of speed). We believe that the card-based payment systems' dispute resolution procedures accomplish these ends without sacrificing many of the important values protected by the public legal system, including due process and fairness, and therefore, can serve as a model for rethinking dispute resolution more generally.

In Part I we sketch the structure of disputes and briefly compare public legal systems to card-based payment systems' dispute resolution processes. In Part II, we describe card-based payment systems' technology in more detail as part of an examination of their use of reputation and incentives. In Part III, we discuss the dispute resolution procedures in detail. In Part IV we examine the role of the state in shaping those systems. Part V concludes with our assessment of the viability of modeling public legal system reforms on card-based payment systems.

\section{RESOLVING DisPUTES}

By proposing card-based systems' dispute resolution systems as models for reforming the courts, we are suggesting a radical rethinking of dispute resolution. ${ }^{6}$ To evaluate this alternative, we examine several core rea-

5 We use the somewhat awkward term "card-based payment system" because there are many types of such systems, including "general purpose and limited-purpose credit cards, automated teller machine (ATM) cards, debit cards, smart cards, and check guarantee cards." MICHAEL AURIEMMA ET AL., The BANK CREDIT CARD Business 1, 2 (2d ed. 1996). All of these types of cards offer at least the potential for the dispute resolution systems described here.

6 The limited legal literature that discusses card based payment systems' dispute resolution processes has, thus far, largely rejected them as a model. At times the reasons for this rejection are not clear. See, e.g., William Krause, Do You Want to Step Outside? An Overview of Online Alternative Dispute Resolution, 19 JOHN MARSHALL J. COMPUTER \& INFO. L. 457, 472 (2001) (contending that card based systems' dispute resolution systems have "limited applicability" to dispute resolution generally because a "few disgruntled, vocal consumers can convince many others that there is an unacceptable risk. Even small anecdotal evidence of online misfortune is potential poison in the water."). Prof. Krause does not 
sons that disputes require resolution by outsiders, which we describe to allow us to benchmark the alternative against the features of the public legal system. $^{?}$

When parties have a dispute, they have a choice between "litigating" the dispute (i.e. using a dispute resolution mechanism that does not require agreement on the ultimate resolution, although it may require agreement on the process) and "settling" the dispute (i.e. agreeing on the ultimate resolution without an outside decision-maker reaching the final decision). ${ }^{8}$ In this section we briefly sketch the structure of disputes and compare the approaches of the public legal system to the card-based payment system dispute resolution processes. ${ }^{9}$

\section{A. Approaches to Disputes}

We assume that the decision to litigate disputes between two parties occurs because one (or more) of the following conditions exists: (1) disagreement between the parties as to the facts; (2) disagreement between the parties as to the appropriate rule governing the dispute; (3) tactical advantages that reward a party for delaying resolution of the dispute; (4) the transactions costs of settlement exceed those of litigation; (5) one or more of the parties may be using the dispute to send a signal about its future behavior (or for other strategic reasons) ${ }^{10}$ and the signal's value may exceed the savings from resolving the dispute without litigation; and (6) attempts to "roll the dice" and win because of the presence of random elements" in the

elaborate but this argument strikes us as implausible, particularly since the online services he suggests will succeed have not displaced the card-based systems' procedures. Id.

7 We use the term "public" to refer to government courts, law, and so forth.

8 Thus our definition includes mediation within settlement and arbitration within litigation. We recognize that this definition imposes a binary settle/litigate framework on a process that is a continuum between pre-filing settlement through settlement before the final decision is rendered on appeal to a final judgment upheld on appeal, but the key distinction appears to us to be whether an outsider renders the final decision or whether a resolution is voluntarily agreed upon by the parties.

9 We provide a more detailed description of the card-based systems' process in Section II below.

10 In IP cases, for example, the owner of an IP right may have strategic reasons for litigating unrelated to the costs and benefits from the particular suit. See, e.g., Olufunmilayo Arewa, Blocking, Tackling and Holding: Boundaries, Marking and Strategic Business Uses of Intangibles 3 (Case W. Reserve Sch. of L., Working Paper, Case Legal Studies Research Paper No. 04-13, 2004), available at http://ssm.com/abstract=586483 (last visited May 31, 2005) (arguing that "broad grants of intellectual property rights combined with intangibles paradigm business practices permit and even encourage the holders of such rights to use them as strategic weapons in a manner that may actually be a disincentive to future innovation.").

11 See Gillian K. Hadfield, The Price of Law: How the Market for Lawyers Distorts the Justice System, 98 MiCH. L. REv. 953, 970-71 (2000) (noting existence of "Professional platitudes such as, 'litigation is always a crap shoot' or 'give a problem to 10 different lawyers and you'll get 11 different answers."”). 
dispute resolution process. ${ }^{12}$ If none of these are present, no dispute or reason to litigate exists. We will briefly consider each of these possible causes of a decision to litigate. ${ }^{13}$

Where the parties disagree as to the facts, the primary function of the dispute resolution process is to prompt the exchange of information which brings the parties' divergent view of the facts closer together, making resolution possible. ${ }^{14}$ Thus, for example, where the parties disagree about whether a debt is owed, the creditor's provision of documentation showing that the debtor incurred the debt would resolve the disputed factual issue and could cause the debtor to reevaluate the facts and recognize the debt. Resolving factual disputes is a "socially useful" function" ${ }^{15}$ of a dispute resolution system.

In the public legal system, such disputes are handled by a demand by the creditor for payment. If the debtor does not pay in response to the demand, a formal legal complaint must be filed. ${ }^{16}$ The parties exchange legal

12 We thus expand the traditional categories of differences in information and differences in optimism. See, e.g., Robert H. Gertner, Asymmetric Information, Uncertainty, and Selection Bias in Litigation, 1993 U. CHI. L. SCH. RouNDTABLE 75, 79 (1993) ("There are numerous possible explanations for why inefficient litigation may occur despite the cost savings from settlement. Most can be classified as either differences of opinion between litigants or differences of information between litigants.").

13 Of course, more than one reason may be present in any particular instance.

14 "Information is the lifeblood of [litigation]. Litigants battle to learn information, to conceal information, and to spin information so that it might better persuade judges, juries, and opponents to accept their view of the facts and law ... it is probably no exaggeration to claim that litigation is all about the process of learning information, the cost of learning information, and the optimal response to information." Joseph A. Grundfest \& Peter H. Huang, The Unexpected Value of Litigation 1 (Stanford L. Sch., John M. Olin Program in L. \& Econ. Working Paper No. 292, 2004) available at http:// ssrn. .com/abstract $=585803$.

15 We define "socially useful" to mean instances in which an institution increases the participants' total utility, not simply allocating a share of wealth to any particular party ("zero sum game"). Voluntary trades are thus the paradigmatic case, since they must increase the joint value in order to occur. This differs from the neoclassical definition of efficiency, since a Kaldor-Hicks efficient transaction would not meet our definition and yet would meet the neoclassical definition of efficiency. In the case of a dispute, of course, the loser's utility is reduced by the loss of the dispute if the parties' utilities are measured ex post. If they are measured ex ante, however, we contend that the expected utility of a dispute resolution institution is greatest for those institutions which provide the greatest possibility of factually-correct outcomes. This limitation is more rigorous than the test of neoclassical efficiency and is, we think, more consistent with a Hayekian approach to law. See FrIEDRICH A. HAYEK, RULES AND ORDER 96-97 (1973) (question to be decided by judge "will not be whether the parties have obeyed anybody's will, but whether their actions have conformed to expectations which the other parties had reasonably formed because they corresponded to the practices on which the everyday conduct of the members of the group was based."); See also Andrew P. Morriss, Hayek and Cowboys: Customary Law in the American West, 1 N.Y.U. J. L. \& LIBERTY 35, $41-42$ (2005) (describing Hayekian dispute resolution).

16 Of course, summary collection procedures exist in the courts to reduce the transactions costs of handling more routine debt collections. Even these, however, involve more elaborate procedures than card-based dispute resolutions systems routinely use. 
papers, conduct discovery by serving each other with written requests for production, requests for admission, and interrogatories, conducting formal depositions, and so forth. Disputes during this process may result in the need for intermediate decisions by a court. If the parties cannot agree to settle the dispute, a trial is conducted and a decision reached by either a judge or jury (depending on the circumstances). Appeals to higher courts may follow. At all stages, both parties are likely to be represented by attorneys; the court will employ expensive decision makers (legally trained judges, staff, and multiple lay decision makers on juries); the process takes months and, often, years. As an example, consider that under a fixed rate plan designed to reduce legal costs, the evaluation of a case and an initial complaint costs $\$ 6,000$ if the amount in dispute is under $\$ 150,000 .^{17}$

Within the payment systems context, this fact pattern arises when a cardholder disputes a charge and alleges that he did not use the card to incur the charge. In this situation, the cardholder complains first to the financial institution that issued the card. In the process that we outline in more detail below, the merchant attempts to retrieve a copy of the receipt and, if it is found, a copy is provided to the consumer. In many cases, this process ends the dispute, as the merchant either can or cannot prove the receipt exists. When it does not, the dispute is resolved after the financial institutions involved (on both the merchant's and the cardholder's side) have exchanged information through a highly structured process that specifies what information is to be exchanged and when the exchange is to occur. This process provides both positive financial incentives and negative substantive incentives for prompt compliance with the information exchange rules, and leads to a decision without the involvement of legally-trained personnel. Such disputes are required by the card system's rules (which are described in detail below) to be resolved within a relatively short, fixed period of time (typically within weeks rather than months).

When the parties disagree about the law, but not necessarily the facts, the primary function of the dispute resolution process is to clarify the legal rules which are applicable to the dispute. For example, where one party believes the case will turn on legal rules concerning how to interpret an employment agreement while the other believes it turns on the rules governing the fiduciary obligations to minority shareholders in a close corporation, ${ }^{18}$ the dispute resolution process classifies the legal character of the dispute and resolves the uncertainty. As with resolving factual disputes, resolving uncertainty about the applicable law is a socially useful function of the dispute resolution system.

17 Hadfield, supra note 11 , at 958

18 See, e.g., Jordan v. Duff and Phelps, Inc., 815 F.2d 429 (7th Cir. 1987) (dispute between majority opinion by Judge Easterbrook, holding case was a question of rights of a shareholder of close corporation, and dissent by Judge Posner, arguing case was a question of the rights of an at-will employee). 
In the public legal system, formal legal proceedings must be initiated to resolve such disputes, as described above. The proceedings are comparatively unstructured, parties generally have legal counsel at all stages, and decision makers are expensive. In the payment system context, an example of a dispute over which rules govern is a consumer's warranty-related claims to the financial institution that issued the card used to purchase the underlying good or service. The consumer contends that the product is defective in a quality dimension that is covered by the warranty; the merchant denies that the relevant dimension is covered. As we describe below, both the consumer and merchant must follow predefined rules in resolving the dispute. Briefly, the consumer must first make a good faith attempt to resolve the dispute with the merchant before raising the issue with the consumer's financial institution. If the merchant and consumer fail to resolve the dispute, the consumer raises the disputed item with the issuer. That dispute will be resolved using the structured, technology-based dispute resolution process described below. The process is administered by nonlawyers, usually by telephone. The decision is reached through either the procedure or the substance of the applicable rule, typically within about a month or less. Or, if the dispute continues to through the maximum number of phases including a formal arbitration procedure (with a non-lawyer arbitrator), the maximum elapsed time from dispute to decision is about five months.

Where there is no fundamental disagreement over either the facts or the law, one party may still prefer to submit a dispute to resolution through a dispute resolution process to contracting for a settlement because the party believes it will benefit from the process itself. Thus, for example, where a party recognizes that it is liable but nonetheless believes it can earn a return on the amount it must ultimately pay in excess of any prejudgment interest obligations or that the opposing party may settle for a lower amount because of a pressing need for cash, there is an incentive to litigate to delay the inevitable payment. ${ }^{19}$ Where one party is gaming the system there is no socially beneficial function of the litigation since the gain of one party is at

19 For example, Prof. Elihu Inselbuch argues that

[t]he real source of delay in the tort system . . . arise[s] from the economics of the tort system and the insurance industry, which combine to create an impetus for defendants to withhold realistic settlement offers. Insurance companies earn their profits from the investment of premiums that they collect from their insured. The longer the insurers can delay payments to plaintiffs, the greater the return they will realize on the funds withheld. The insurers' incentive to exploit the time value of money is compounded by a tort system that imposes no costs on them or their insured clients for delay in the payment of claims. If an insurer can settle a case on the eve of trial for the same amount it would have cost to settle the claim years earlier when the plaintiff first sued, then no incentive exists to move the insurer to settle and pay the claim earlier. Indeed, given that the insurer is given a free float of the amounts owed the tort victim, the system gives insurers and self-insured defendants a huge incentive not to settle early because an early settlement would forfeit the time value of the money.

Elihu Inselbuch, Contingent Fees and Ton Reform: A Reassessment and Reality Check, 64 LAW \& CONTEMP. PROBS. 175, at 183 (2001). 
the expense of the other party rather than as a result of increasing the size of the joint surplus.

In the public legal system, gaming the system is difficult to police, as parties have a great deal of freedom to structure their legal pleadings and actions. Even after repeated, clear cases of abuse, for example, the public legal system is rarely able to restrict future abuses by plaintiffs. ${ }^{20}$ The problem for the public legal system is two-fold. First, there are no mechanisms that identify gaming behavior because there is no institutional remedy which can identify such behavior based on a comparison of particular parties' behavior to other transactions. Second, even where such information is found on an ad hoc basis, the public legal system is often reluctant to sanction parties who game the system because doing so forecloses access to the courts.

In the payment system context, there are also opportunities for gaming behavior. For example, if a consumer complains about a charge, during the dispute period the amount in dispute is temporarily debited from the merchant's account and credited back to the consumer. This provides the consumer with additional credit, since charges are not applied to the account during the dispute. (Once the dispute is resolved, the temporary debits and credits are either reversed or made permanent.) Consumers who repeatedly game the system, however, self-identify themselves to their card-issuer. Since the issuer bears some of the costs from consumer complaints, these consumers' poor reputation for honesty can be a basis for the issuer to cancel the consumers' cards. The distinctive feature of card-based payment systems is their ability to make use of the parties' reputations in controlling attempts to game the system. ${ }^{21}$

In some situations, the parties may simply be unable to resolve their dispute because of particularly high transactions costs involved in settlement compared to the transactions costs of the dispute resolution system

20 Prisoners who abuse in forma pauperis filings are the only area where the courts regularly impose such sanctions. See, e.g., Slicher v. Thomas, 111 F.3d 777, 780-782 (10th Cir. 1997) (sanctioning a pro se prisoner litigant who had filed 33 matters with the 10th Circuit from 1989 to 1997, most of which were summarily dismissed, and concluding that court had "determined to call a halt to Mr. Schlicher's wasteful abuse of judicial resources" by barring him from future filings in forma pauperis except in cases alleging an imminent danger of personal injury, forbidding him to file pro se pleadings, and requiring production of specific information on his litigation to accompany any filings). Even in these cases, however, the sanctions are imposed only after repeated abuses, and are limited in their ability to forestall future abuses. Further, no systemic learning about how to deter others from similar abuses occurs.

21 Reputation can serve two important functions. First, reputation may be a means of dealing with non-verifiable information about a customer. Second, reputations aggregate information about discrete events, with the aggregation providing more information than the sum of the information of the individual events. For example, knowledge is gained about a customer with multiple disputes with merchants in which the facts are unclear by virtue of there being multiple disputes beyond the ambiguous information contained in each dispute. 
itself. For example, it may be too costly to educate a corporate defendant's decision making authority about the facts and law concerning a small dispute once the opportunity costs of the decision makers' time is considered, and so litigating may be less expensive than settlement. Here the invocation of the dispute resolution process is socially useful only because of the relative transactions costs of litigation and settlement. In the public legal system, there are high transactions costs of understanding the legal system's substantive and procedural rules, as is demonstrated by, and perhaps caused by, the extensive involvement of lawyers in all stages and types of public legal system disputes. In the payment system context, however, these transactions costs are reduced significantly by the use of a comprehensive set of rules categorizing disputes and standardizing procedures, allowing an almost lawyer-free dispute resolution process. Moreover, standardization itself reduces the cost of participation by expensive participants. Many financial institutions, for example, regularly have summary reports reviewed by high level employees. These reports identify outliers and anomalous transactions, which can thus attract high level input, while routine cases do not waste resources. Further, the shifting of costs to losing parties provides an additional motivation for participants to prefer settlement to litigation. ${ }^{22}$

Finally, to the extent a random element exists in a dispute resolution process, parties who know that an accurate process would find them liable may be willing to "roll the dice" through litigation, in effect seeing the additional costs of litigation over settlement as the price of a lottery ticket whose prize is elimination of the obligation. Thus, for example, where both parties to an oral contract know that the contract was properly made, one party may be unwilling to perform because of the positive probability that a jury will not believe the plaintiff's truthful testimony about the contract's formation, believing instead the defendant's false testimony. In this case the dispute resolution process does not serve a socially useful function and the decision to litigate is motivated solely by the existence of a substantial enough random element.

The public legal system's reliance (in the United States) on lay juries includes a relatively large random element, since it reduces the predictability of trial outcomes, perhaps best captured by the oft-repeated comment

22 In the payment systems context, certain merchants and consumers may be less organized and responsive than others. Since one aspect of the payment system's dispute resolution process, as described below, is grounded on responsiveness, a non-responsive party is likely to lose the dispute permanently. Since neither party knows how responsive the other party will be in a dispute, there is always a chance that the other party will be a slouch and the likelihood of winning increases substantially. This possibility is not a problem to the dispute resolution system within the payment system because all disputes are tracked. Cardholders who appear to be gaming the system may have their accounts canceled or not renewed. 
that "you never know what a jury will do."23 Card-based payment systems" dispute resolution systems, by contrast, rely more heavily on structured analyses, which provide predictability. Moreover, since the financial institutions and networks involved in card-based payment systems are repeat players, they profit from reducing randomness and invest in data analysis to do so.

Dispute resolution processes thus serve socially useful functions when they resolve factual and legal disputes and privately useful, but socially costly functions when dispute resolution processes have characteristics that motivate parties to litigate when no factual or legal dispute exists. In evaluating alternatives to the public legal system, the relative performance of alternatives in addressing each of these scenarios is one means of evaluating their value. In particular, the ability of a legal system to focus its resources on socially useful categories of dispute resolution is important indicia of success.

Our preliminary account of card-based payment systems points toward several important differences between card-based payment systems' dispute resolution processes and those of the public legal system. First, card-based payment systems are able to make use of lower cost inputs because of the more structured nature of their processes. Second, card-based payment systems make extensive use of positive and negative incentives and reputation in securing compliance with procedures, reducing enforcement costs. Third, card-based payment systems collect information that allows them to eliminate future socially costly disputes by imposing constraints on participants.

\section{B. Dispute Resolution as a Technology}

Let us consider a somewhat stylized version of dispute resolution, to identify the civil justice system's features that can serve as a benchmark for the card-based systems' dispute resolution processes by examining the technology the public courts use to resolve disputes with respect to three key attributes: (1) the provision of factual information to the decision maker; (2) the means of deciding questions of both fact and law when the information provided is insufficient to compel a particular resolution clearly

23 See, e.g., ROBERT A. KAgAN, AdVERSARIAl LEgAlism: THE AMERICAN WAy OF LAW 127 (2001) (listing unpredictable "lawyer-driven, jury-centered methods of adjudication" as a distinguishing feature of U.S. legal system); Gary T. Sachs \& Neal W. Settergren, Juries Should Not Be Trusted to Decide Maritime Cases, 34 J. MAR. L. \& COM. 163, 170 (2003) ("A better instrument could scarcely be imagined for achieving uncertainty, capriciousness, lack of uniformity, disregard of former decisionsutter unpredictability."). 
and conclusively; ${ }^{24}$ and (3) the methods of correcting decisions or ensuring correct, unbiased initial outcomes.

The rules of civil procedure and evidence used in civil trials in the various common law jurisdictions provide one approach to accomplishing this objective. The quite different rules used in civil law jurisdictions provide another ${ }^{25}$ How a legal system (public or private) handles each of these functions depends on the incentives and constraints created by the system's rules and its technology. For example, Rule 55 of the Federal Rules of Civil Procedure encourages participation in the dispute resolution procedure of the federal courts by allowing parties whose opponents do not respond in a timely way to obtain default judgments, and Rule 11 creates disincentives for parties to make misrepresentations by penalizing the lawyers who sign pleadings containing the misrepresentations.

In general, the public legal systems rely primarily on notice pleading, a system of rules in which "the factual allegations contained in the pleadings are judged by lax standards, because it is understood that more detailed knowledge of the facts must await further development through the elaborate discovery process provided for in the rules."26 These rules place few limits on the participants' ability to conduct expensive and time consuming searches for evidence that may fit the broad set of claims of which the pleadings give "notice."

The rules governing disputes in the public courts are largely built around encouraging voluntary compliance with the rules through a combination of appeals to professional norms and sanctions for violations. The rules rarely include positive incentives, such as cash payments, to encourage compliance. The problem with this approach is that professional obligations require attorneys to put compliance with rules ahead of their clients' and, sometimes, their own personal financial interests. ${ }^{27}$ Furthermore,

24 [1] a controversy should arise between two men concerning the ownership of property, and there be no statute upon the subject, the unwritten law must, nevertheless, decide it. No matter how novel the question, it must be determined. It would not be endurable that one man should hold unchallenged possession of property to which another honestly laid claim, for the reason that the case was so novel as to render it difficult to determine to whom it justly belonged. Society may leave a criminal unpunished; private citizens do not feel an additional burden on this ground; but it cannot leave private controversies undecided, or to be decided by force.

JAMES C. CARTER, THE PROPOSED CODIFICATION OF OUR COMMON LAW 34-35 (1884).

25 The universe of possible approaches is considerably broader than the set of approaches used by various official legal systems.

26 Martin H. Redish, Electronic Discovery and the Litigation Matrix, 51 DUKE L. J. 561, 606 (2001).

27 See, e.g., Hadfield, supra note 11, at 955 ("the very concept of professionalism requires that a disregard of economic incentives be a moral duty for the professional."); see also Philip J. Havers, Take the Money and Run: Inherent Ethical Problems of the Contingency Fee and Loser Pays Systems, 14 Notre DAME J. L. ETHICS \& PUB. POL'Y 621, 625 (2000) ("Because of this large personal financial stake [due to contingent fees], the attorney can no longer look upon his practice of law as one devoted primarily to justice. Besides calling into question this basis of our professional rules that he is now 
negative sanctions are discounted for the probability that one will not be caught. ${ }^{28}$ The public courts thus are handicapped by their inability to make systematic use of the reputations of either the lawyers or the parties and the lack of certainty that those violating the rules will be identified and punished.

With respect to the technology of dispute resolution, the public courts depend primarily on live testimony before the decision maker, with crossexamination by the opposing counsel and observation by the decision maker to test the veracity and accuracy of the testimony. The rules' approach may vary with the nature of the dispute or information. For example, in fraud cases, where the nature of the claim raises concerns about the factual basis of the claim, Federal Rule 9(b) requires more specific pleading than in a negligence case. ${ }^{29}$ Similarly, the federal rules of evidence exclude much hearsay evidence on the grounds that it is inherently unreliable. ${ }^{30}$ While an improvement over many earlier technologies (e.g. trial by ordeal) ${ }^{31}$ this technology remains largely unchanged since the early twentieth century introduction of modern civil procedure, ${ }^{32}$ and has significant imperfections.

more likely to ignore or, at the least, will play with at the margins, the negative aspects of the contingency system work their way into the sacred relationship between the attorney and client.").

28 Richard A. POSNER, ECONOMIC ANALYSIS OF LAW 220 (6th ed. 2003) (noting "growing empirical literature on crime" that shows people respond to changes in "opportunity costs, in the probability of apprehension, in the severity of punishment, and in other relevant variables ....").

29 F.R.CIV. P. 9(b) ("In all averments of fraud or mistake, the circumstances constituting fraud or mistake shall be stated with particularity. Malice, intent, knowledge, and other condition of mind of a person may be averred generally."). Rule 9(b) has been criticized heavily. See, e.g., Christopher M. Fairman, An Invitation to the Rulemakers-Strike Rule 9(b), 38 U.C. DAVIS L. REV. 281, 282 (2004) ("At best, Rule 9(b) is an anachronism-harkening back to the abandoned pleading practices of the past that spawned the modern Federal Rules.")

30 See Paul F. Kirgis, Meaning, Intention, and the Hearsay Rule, 43 WM. \& MARY L. REV. 275, 301-06 (2001) for a discussion of the justifications for hearsay exclusions.

31 See, e.g., J.H. BAKER, AN INTRODUCTION TO ENGLISH LEGAL HISTORY 5 (3rd ed. 1990):

The procedure [in early English law] in contentious matters was calculated to avoid reasoned decision-making [which some times included] the physical test of an ordeal. . . Ordeals involved an appeal to God to reveal the truth in human disputes, and they required priestly participation to achieve this rapport with the Deity. . . [ []n England, they usually took the form of fire or water. In the former, a piece of iron was put into a fire and then in the party's hand; the hand was bound, and inspected a few days later: if the burn had festered, God was taken to have decided against the party. The ordeal of cold water required the party to be trussed and lowered into a pond; if he sank, the water was deemed to have 'received him' with God's blessing, and so he was quickly fished out.

The parody of such procedures in the film Monty Python and the Holy Grail, in which Sir Bedevere examines a purported witch and concludes that if she weighs the same as a duck then she is a witch, is humorous precisely because of the seeming ridiculousness of early English trial methods. See http://www.rit.edu/ smo4215/monty.htm\#Scene\%205 (for a link to the script segment on the trial listed under Scene 5) (Last visited February 7, 2005).

32 See generally Stephen N. Subrin, How Equity Conquered Common Law: The Federal Rules of Civil Procedure in Historical Perspective, 135 U. PA. L. REV. 909, 1001-1002 (1987) (describing evolution of modern civil procedure and tracing contemporary problems to structural design of rules). 
To correct errors and biases, courts rely on appeals, which focus primarily on legal questions rather than factual issues. ${ }^{33}$ To prevent errors and biases, the structure of compensation and working conditions for judges aim at eliminating conflicts of interest. ${ }^{34}$

In cases where the outcome depends upon resolution of factual uncertainty, the lack of technological progress is unsurprising since many such cases ultimately depend on choosing between two competing versions of the truth as set out by witnesses, physical evidence, and documents. Particularly in the case of single episode interactions between strangers (e.g. a transaction by a traveler away from home or an automobile accident), the involvement of the public legal system's dispute resolution process only after the dispute exists prevents any other approach, since the events leading to the dispute are over before the legal system is involved. Therefore, only a retrospective accounting of the facts is possible.

The lack of technological progress is also not surprising given the substantial monopoly power of the legal profession in disputes in the public legal system..$^{35}$ Monopolies generally tend to under-produce innovations. ${ }^{36}$ Lawyers' role as one of the major costs of the public legal system suggests that cost-reducing innovations would likely reduce their profits. Even the few cost-reducing innovations which have been introduced, such as the use of paralegals to do work previously done by lawyers, are limited by the legal profession's control over the practice of law. ${ }^{37}$

The formal legal system's methods of resolving disputes thus include (at least) four problematic features. First, there are a substantial number of single event litigations, where one or more parties is not a repeat player. The lack of repeat interactions reduces the usefulness of parties' reputations in creating incentives for honesty and rule compliance. Of course, lawyers

33 POSNER, supra note 27, at 601.

34 See Richard A. Epstein, The Independence of Judges: The Uses and Limitation of Public Choice Theory, 1990 BYU L. REV. 827 (1990); Richard A. Posner, What Do Judges Maximize (The Same Thing Everybody Else Does), 3 S. CT. ECON. REV. 1 (1993).

35 See, e.g., Hadfield, supra note 11, at 999 :

The market for lawyers is fundamentally noncompetitive. As a consequence of the complexity of legal reasoning and procedure, the profession's derived monopoly on the legitimate use of coercion, and the unification of the profession to serve the diverse needs for access to law, the price of law that emerges from the free market for lawyers is too high.

363 PhILlip E. AREEDA \& HERBERT HOVENKAMP, ANTITRUST LAW: AN ANALYSIS OF ANTITRUST PRINCIPLES AND THEIR APPLICATION II 631 (1996) ("'[W]e worry about monopoly because of its generally evil result or potentialities: reduced output and higher prices, diminished incentives for innovation, and fewer alternatives for suppliers and customers.").

37 See Carl M. Selinger, The Retention of Limitations on the Out-of-Court Practice of Law by Independent Paralegals, 9 GEO. J. LeGAL ETHICS 879 (1996) (discussing means of limiting the impact of independent paralegal practice on lawyers through ethical rules); Benjamin H. Barton, An Institutional Analysis of Lawyer Regulation: Who Should Control Lawyer Regulation-Courts, Legislatures or the Market?, 37 GA. L. REV. 1167, 1189 (2003) ("Raising entry barriers has been the sine qua non of the formation of modern bar associations and lawyer lobbying."). 
are by definition repeat players, ${ }^{38}$ but the size of the legal profession in many larger communities and the limited control measures available to courts means that reputation effects are often diluted even for attorneys.

Moreover, the public legal system usually makes only limited use of information about parties' prior conduct. ${ }^{39}$ Legal rules limit the circumstances in which even previous formal disputes can be considered. ${ }^{40} \mathrm{Al}$ though the card-based payment systems do not use prior complaints to determine the outcome of a particular dispute, the financial institution may cancel or not renew the account of a consumer who frequently initiates formal disputes because the costs of servicing that consumer are larger. Similarly, merchants that receive a significant number of formal disputes will be required by the financial institutions handling their accounts to pay a higher discount rate $^{41}$ to gain the ability to accept card based payment systems, or in egregious cases, abusive merchants may be expelled from the system altogether. ${ }^{42}$

Second, there is a significant random, or at least, a non-merits related element to dispute resolution, largely due to the role of juries ${ }^{43}$, but also

38 See, e.g., W. Bradley Wendel, Informal Methods of Enhancing the Accountability of Lawyers, 54 S.C. L. REV. 967, 970 (2003) ("A repeat-player lawyer with a contrary reputation faces numerous costly obstacles, such as the refusal by other lawyers to agree to reasonable schedule changes, the need to memorialize every agreement in writing, and difficulty making credible commitments."). Wendel uses accounts of lawyers in Charleston, S.C. and the Chicago municipal courts to argue that reputational constraints are powerful constraints on the practice of law. He notes, however, problems with the form of these constraints, including the possibility that the relevant reputational constraint is the lawyer's allegiance to his legal community rather than to the client, encouraging a tradeoff of the client's interest for the lawyer's, and the possibility that the relevant legal community norms themselves may be problematic (e.g. to exclude minorities from lucrative areas of law practice).

39 We recognize that we are speaking at a high level of generality-there are a variety of public legal systems (federal, state, small claims, bankruptcy, etc.) and each has its own rules.

40 Collateral estoppel and res judicata principles, of course, allow some use.

41 The discount rate is the fee that the merchant pays to the financial institution processing these transactions on their behalf. The fee is typically a percentage of the transaction. See MASTERCARD DiCTIONARY (December 2003), at 34.

42 See Henry H. Perritt, Jr., Dispute Resolution in Cyberspace: Demand for New Forms of ADR, 15 OHIO ST. J. ON DISP. RESOL. 675, 691-92 (2000). Higher fees and expulsion serve as important limits on fraudulent uses of the card systems. See, e.g., Barry Cutler, Statement of the Federal Trade Commission before the Select Committee on Aging, Subcommittee on Health and Long-Term Care, Committee on Small Business, Subcommittee on Regulation, Business Opportunities, and Energy, U.S. House of Representatives (June 21, 1991), in PRACTISING LAW INSTITUTE, RECENT TRENDS IN TElemarKeTING FraUd, Nov. 1991, (759 PLI/Corp 479) at 505 (describing how use of 900 numbers substituted for credit card billing in fraud schemes, and how "this option solves several problems for the fraudulent telemarketer. First, the company need not meet the criteria that major credit card companies impose for obtaining a merchant account with a bank. Second, the company is able to use a payment system that lacks the dispute resolution procedures and other safeguards for credit card transactions found in the Fair Credit Billing Act.").

43 See, e.g., W. Kip Viscusi, Punitive Damages: How Jurors Fail to Promote Efficiency, 39 HARV. J. ON LEGIS. 139 (2002) (describing experiments demonstrating jurors' failure to follow instruc- 
attributable to quality issues in the judiciary. ${ }^{44}$ Because we rarely observe parties outside the formal legal system investing in either randomly chosen lay panels or individuals chosen through the political process to decide disputes, we can also infer that such panels' and judges' primary advantages do not lie in accuracy or reduced transactions costs. This random element, of course, increases the number of times the process is invoked in a socially costly way.

Third, litigation in public legal systems is costly. ${ }^{45}$ The costs are due to both the length of proceedings and the involvement of large numbers of highly trained and highly compensated individuals, including both judges and lawyers. The success of privately provided alternative dispute resolution systems which offer reduced costs ${ }^{46}$ suggests that the public legal system's costs are higher than necessary to resolve at least some disputes.

Fourth, the public legal system is involved in many disputes only ex post (although parties may change their behavior ex ante in anticipation of litigation). The public legal system cannot, therefore, dictate parties' behavior in advance of disputes. Thus, for example, the negligence rule in tort law may produce efficient levels of care by potential tortfeasors in some situations, ${ }^{47}$ but it does not influence decisions on activity levels leading to inefficiently high activity levels. ${ }^{48}$ Intervention in transactions or other interactions before a dispute arises may be a less costly means of handling a matter than ex post dispute resolution. ${ }^{49}$

tions in assessing punitive damages and resulting penalties for firms that engage in risk analysis). On juries more generally, see generally Dan Simon, $A$ Third View of the Black Box: Cognitive Coherence in Legal Decision Making, 71 U. CHI. L. REV. 511, 550-58 (2004) (discussing cognitive biases introduced into jury decision making by the structure of trials).

44 See, e.g., Geoffrey P. Miller, Bad Judges, 83 TEX. L. REV. 431, 431 (2004), who notes that "In jurisdictions across the country, complaints are heard about judges and magistrates who are incompetent, self-indulgent, abusive, or corrupt. These bad judges terrorize courtrooms, impair the functioning of the legal system, and undermine public confidence in the law. They should not be allowed in office, yet many retain prestigious positions even after their shortcomings are brought to light. The situation, moreover, does not appear to be under control."

45 See Graham C. Lilly, The Decline of the American Jury, 72 U. COLO. L. REV. 53, 57-58 (2001) (describing costs of trials).

46 See, e.g., Barak D. Richman, Firms, Courts, and Reputation Mechanisms: Towards a Positive Theory of Private Ordering, 104 CoLuM. L. REv. 2328, 2341-42 (2004) (describing categories of efficiencies available in private dispute resolution).

47 See, e.g., STEVEN SHAVEll, ECONOMIC ANALYSIS OF ACCIDENT LAW 16 (1987) (describing circumstances under which model predicts negligence rule will produce optimal outcome).

48 Id. at 23-24 (noting that injurers do not "have a reason to consider the effect that engaging in their activity has on accident losses. Consequently, injurers will be led to choose excessive activity levels.").

49 See, e.g., Michigan Manufacturers Association, Insurance \& Benefits, http://www.mma-net.org/ insurance/workers_comp.asp (last visited Sept. 12, 2005) ("Amerisure combines the expertise of experienced professionals and sophisticated programs to find solutions to plant safety issues, prevent losses and, ultimately, reduce insurance costs."). 
Card-based payment systems' dispute resolution systems offer a different approach to solving each of these problems. Card-based payment systems convert all interactions between participants into repeat player transactions. ${ }^{50}$ Rather than a single episode merchant-customer interaction, the use of a card-based payment system to make a purchase creates a series of related, repeat player transactions: merchant-bank, bank-payment mechanism provider, ${ }^{51}$ payment mechanism provider-bank, and bankcustomer. Card-based payment systems harness reputations to prevent and resolve disputes because these related repeat transactions are counted and analyzed. The value of the relationship itself is defined by the analysis of the transaction counts, and conclusions drawn about the revenue, cost, and profit of the overall relationship. These systems also structure the underlying transactions, dictating features of the cards, recordkeeping, and transaction processing which decrease the frequency of disputes and the nonobjectively verifiable aspects of those disputes which do occur, reducing the scope for randomness in decisions. Card-based payment systems' dispute resolution procedures also drive the processing of claims down to relatively low level employees and contain incentives for constant cost reductions, thereby lowering transaction costs. In the following section we examine how card-based payment systems accomplish these results.

\section{PAYMent SyStems as A TEChNOLOGY}

In order to understand how incentives and features in the card-based payment dispute resolution systems lower costs, we must first understand how the payment system itself works. Some features will be difficult to translate to other dispute resolution systems; other aspects are more readily applicable to dispute resolution in general. Distinguishing among these features and incentives requires an examination of the technology itself.

50 This point is sometimes missed in the literature on e-commerce, which overlaps to some extent with the card-based payment systems literature. For example, Prof. Llewellyn Joseph Gibbons calls for government intervention into e-commerce consumer contracts to "encourage the development of consumer institutions to counter the market advantages enjoyed by repeat players (such as merchants) ...." Llewellyn Joseph Gibbons, Creating a Market for Justice; a Market Incentive Solution to Regulating the Playing Field: Judicial Deference, Judicial Review, Due Process, and Fair Play in Online Consumer Arbitration, 23 Nw. J. INT'L L. \& BUS. 1, 6-7 (2002).

51 We use the term "payment mechanism provider" to cover associations, such as VISA and MasterCard; historically closed networks, such as American Express and Diners' Club; and the new, third party networks, such as FirstData, which link the participants in card-based transactions. 


\section{A. Payment Systems}

We define a payment system as the combination of law, contracts, and physical technology that enables the movement of value from one party to another to meet the objectives of the parties involved. ${ }^{52}$ Money is itself a payment system. So are a VISA credit card, a MasterCard debit card, a traveler's check, a bank check, a money order, a stored value card, and a certified check, to name but a few. Different payment systems have varied features and attributes, enabling the users of that payment system to accomplish particular objectives in different ways. Where different payment systems are available, users select among them based on the combination of costs and benefits each payment system offers.

Consider one of the simplest payment systems available: U.S. dollars. ${ }^{53}$ In a typical cash transaction conducted in dollars, a consumer offers a merchant dollars for goods or services. If acceptable, ${ }^{54}$ a merchant transfers the goods or services to the consumer in exchange for physical Federal Reserve notes. ${ }^{55}$ The notes the merchant receives are fungible; that is, they are functionally identical to other, similarly valued notes in circulation. The merchant can then exchange these notes for goods and services from others.

To allow a comparison between dollars and other payment systems, consider the features the dollar offers. There are technical features of Federal Reserve notes which facilitate transactions. The notes include antifraud technology, such as complex printing techniques, watermarks and serial numbers. ${ }^{56}$ Inexpensive technology is available to the note-receiver

52 For an overview of some of the characteristics of payment systems, see generally Jane Kaufman Winn, Clash of the Titans: Regulating the Competition Between Established and Emerging Electronic Payment Systems, 14 BERKELEY TECH. L.J. 675 (1999).

53 See Henry H. Perritt, Jr., Legal and Technological Infrastructures for Electronic Payment Systems, 22 RUTGERS COMPUTER \& TECH. L.J. 1, 5 (1996) ("The definitive payment system is money.").

54 In the United States, prior to 1862 , a merchant could decide which currency to accept, and whether to accept currency at all. See generally Lewis D. Solomon, Local Currency: A Legal and Policy Analysis, 5 KAN. J.L. \& PUB. POL'Y 59 (1996). Once the Civil War era currency laws were adopted, merchants no longer had a choice. Outside of the United States, merchants make this determination every day. Will they accept their own local currency, or some other global currency (i.e., dollars, Euros, Yen, etc.)? Two parties freely elect to accept that currency-with all of the risks inherent in accepting that currency and cash in general.

55 For a summary of legal issues surrounding the merchant acceptance of paper and electronic currency, see James S. Rogers, The New Old Law of Electronic Money, 12-15, 35-52 (Boston College Law School Research Paper No. 62, 2005), available at http://ssm.com/abstract=680803.

56 See Bureau of Engraving and Printing, Anticounterfeiting: Security Features, http://www.moneyfactory.com/section.cfm/7/35 (last visited February 7, 2005); Homer Brickey, Credit Card Firms Battle Crooks with Technology, THE PATRIOT LEDGER, June 24, 1995, at 27, available at 1995 WL 8199543 (describing antifraud technology). 
to evaluate the notes' genuineness. ${ }^{57}$ Even here, reputation plays a role: the notes' continued value depends on the reputation and credibility of the issuer. ${ }^{58}$ Cash also makes anonymous transactions possible and enables merchants to under-report income to tax and regulatory authorities. ${ }^{59}$ Further, the issuer profits from the circulation of the notes (known as seigniorage). ${ }^{60}$ The use of currency has implications for loss allocation, if the currency turns out to be counterfeit and the consumer who used it cannot be located, the merchant bears the cost.

Federal Reserve notes do not provide any dispute resolution characteristics. That is, people cannot invoke the jurisdiction of U.S. government courts merely by denominating a transaction in dollars. Thus, a transaction conducted entirely in dollars among Guatemalans in Guatemala does not allow any of the parties to bring an action in the U.S. courts, although the Guatemalans may make use of the antifraud technology built into the physical notes (i.e. use the detector pens to verify the bill's genuineness) and the U.S. government profits from the seigniorage produced by dollars circulating outside the United States. Transactions originating outside the U.S. can also take advantage of the reputation-based value retention of the currency by using dollars as the basis for transactions physically located outside the United States. ${ }^{61}$

57 See, e.g., http://www.centercoin.com/coin_supplies/counterfeit_detector.htm (last visited February 8,2005 ) (selling for $\$ 4.95$ each, "[d]etector pens are an inexpensive and reliable screening device to be used in conjunction with other counterfeit detection methods"); Wikipedia, Counterfeiting, http://en.wikipedia.org/wiki/Counterfeit (last visited February 8, 2005) (describing historical methods to defeat counterfeiting).

58 See Melvyn King, The Institutions of Monetary Policy, available at http://www .bankofengland.co.uk/publications/speeches/2004/speech208.pdf) (last visited February 8, 2005) (speech by Bank of England Governor describing importance of reputation of monetary institutions).

59 See Richard R. Holley III, One-Card 101: Wachovia Hits the Pit and Becomes the Partner Bank of the UNC One Card, 4 N.C. BANKING INST. 371, 381 (2000) (noting that experience with stored value cards in 1996 Olympics revealed that merchants viewed anonymity as an advantage of cash over card-based systems).

60 See Federal Reserve Bank of Cleveland, Governments and Money, http://www .clevelandfed.org/annual/essay.htm\#compcur (last visited February 8, 2005) ("The authority to print money allows the government to raise revenue because the cost of producing the money itself is far less than the government's command over the purchase of goods and services."). See also Paul D. Glenn, Electronic Banking, Glasser LegalWorks, available at ELCEC GLASS-CEC 85, 105) (1998) ("The government has a lot to lose from the benefits of seigniorage if its role is somehow usurped ... Most of the $\$ 23$ billion that the [Federal Reserve Board] returned to the Treasury last year comes from the seigniorage attributable to the approximately $\$ 400$ billion of cash outstanding at any one time.").

61 The recent decline of the dollar, which has created uncertainty over the future value and stability of the dollar, against many currencies has raised concern over whether the dollar can maintain its position as a desirable currency for non-U.S. transactions, potentially costing the U.S. some of its seigniorage revenue. 
Using cash as a payment system has transactions costs, however. ${ }^{62}$ Physically transferring cash for large payments can be expensive. ${ }^{63}$ Cash's anonymity makes recovering stolen cash difficult. And in single-instance cash transactions between strangers, the parties lack reputational incentives to deal fairly with one another. ${ }^{64}$ By adding additional features that reduce transactions costs relative to those offered by cash, alternative payment systems may provide buyers and sellers with sufficient additional value to allow an entrepreneur to make a profit from charging for the use of the payment system and still offer the user a transaction cost below that of cash. For example, cash transactions over large distances are vulnerable to the theft of the currency while it is in transit.

An early solution to the problem of transporting cash over large distances was the development of the money order. ${ }^{65}$ Money orders provided a substitute for cash that offered the holder protection against theft or loss. However, money orders also had the potential for fraud, since a purchaser could alter a money order after purchase and, if successful, cash it for more than he or she had paid for it. To prevent such fraud, the U.S. post office required that money orders issued by it be cashed only at designated post offices. By sending the cashing post office a separate communication from the issuing post office confirming the value, the potential for fraud was reduced. These restrictions reduced the usefulness of the postal money order, however, because they raised the cost to the recipient in cashing the money order. Competing with the post office for the money order business, American Express developed a secure money order in 1881 whose design

62 On the costs of cash, see Walter A. Effross, Putting the Cards Before the Purse?: Distinctions, Differences, and Dilemmas in the Regulation of Stored Value Card Systems, 65 UMKC L. REV. 319, 325-26 (1997). The development of uniform units of currency reduced the transactions costs of cash. After describing the variety of currency circulating in British colonies in the Caribbean in 18th and early 19th centuries, for example, one author notes that "[w]ith all this complicated variety of currency it must have been extremely difficult undertaking a simple transaction like buying a drink, and the temptation to swindlers was great." CYRIL HAMSHERE, THE BRITISH IN THE CARIBBEAN 156-57 (1972).

63 See Michael K. Salemi, Hyperinflation, in THE CONCISE ENCYCLOPEDIA OF ECONOMICS, available at http://www, econlib.org/library/Enc/Hyperinflation.html (last visited Feb. 8, 2005); ADAM SMITH [GEORge J.W. GoOdMAN], PAPER MONEY 57 (1982) ("In 1923, at the most fevered moment of the German hyperinflation, the exchange rate between the dollar and the Mark was one trillion Marks to one dollar, and a wheelbarrow full of money would not even buy a newspaper."). In general, cash is too expensive to use for large payments even in the absence of hyperinflation. See David A. Balto, Can the Promise of Debit Cards Be Fulfilled?, 53 BuS. LAW. 1093 (May 1998) ("To oversimplify grossly, cash cannot be used for large transactions.").

64 Cash has other transactions costs, including the possibility of the transmission of disease, or at least the fear of transmission. See John Dorschner, Flu Scare Leaves Everyone Waiting, ForT CoLLINS ColoradoAN, Oct. 18, 2004, at 1E. Whether or not there is a scientific basis for the concerns about how disease may have been transmitted through money, some have a fear of this factor, raising the cost (to those market participants) of using cash.

65 Peter Z. Grossman, American Express: The Unofficial history of the People Who BUILT THE GREAT FINANCIAL EMPIRE 83 (1987). 
reduced fraudulent use by incorporating the amount physically into the money order, eliminating the incentive for forgery because tampering would only reduce the value of the money order while eliminating the need to visit the post office to cash the money order. ${ }^{66}$

Similarly, travelers have long used letters of credit to secure cash outside their home banking areas. With a letter of credit, after depositing money with a U.S. bank before leaving the country, a traveler received a letter stating the amount available. By presenting this letter to a foreign bank which had an agreement with the U.S. bank, the traveler could receive cash. When a foreign bank was presented with the letter, it compared the signature of the issuing bank official to a file signature to determine the letter's validity, then noted the amount withdrawn on the letter. Unfortunately this required considerable time at each bank, as everyone "from the charwoman up" would be asked to verify the signature. ${ }^{67}$ Again, American Express innovated, creating the traveler's check as a substitute for the letter of credit. ${ }^{68}$ A crucial feature was American Express's agreement to guarantee the recipient of traveler's checks against fraud and currency risk. ${ }^{69}$

We can compare the payment systems' technologies in these two examples to illustrate how a payment system offers a mix of characteristics which affect its relative advantages in the marketplace. In the case of money orders, the post office had a secure technology (the two-part transmission of information on the value of the money order) which depended in part on the limitation of locations where the money order could be cashed.

66 Id. at 83 ("On the left side of the money order ... [the company] placed nine columns of figures [which] ... depicted all 5-cent denominations from $\$ 1$ to $\$ 10$, the maximum amount of the first express money orders. When a customer purchased an order, the express clerk wrote the name of the payee and the amount on two stubs, and gave one to the buyer and kept the other for company records. But instead of writing an amount on the [money order] itself, he cut the protective margin to the designated sum. The customer could no longer raise the value of the order because the figures simply were no longer there.").

67 Id. at 88.

68 Id. at 91; Dean Perritt suggests that the development of the traveler's check was tied to the creation of a national currency. PERRIT, supra note 53, at 10 ("Nationalizing the currency had the effect of encouraging the invention of a variety of quasi-currencies, most significantly, personal checks and traveler's checks. . . . Historically, the traveler's check was a consolidation of a traveler's letter of credit and separate drafts drawn upon the authority created by the letter."). We see no reason in principle why a traveler's check requires a national currency; we read Perritt's argument to be that the key was the development of a national banking system and the legal disadvantages imposed on private notes as part of the effort to create the national currency.

69 Grossman, supra note 65, at 91 ("By offering such a sweeping guarantee . . Amexco made the [traveler's check] not just another money order, but rather a kind of universal currency."). When World War I broke out, American Express successfully honored its promise to pay on traveler's checks in Europe by building up reserves in the months before the war began. Id. at 123 . As a result, European merchants began to prefer to hold traveler's checks to holding, for example, French currency. Id. at 124 . The company also later added an inspector's office to track down fraud involving traveler's checks. Id. at 212 . 
This approach offered significant advantages over the use of cash for long distance transfers by reducing the risk of loss to the sender, at least partially transforming the sender's risk of physical loss or robbery into a risk of fraud borne by the post office. The post office's technology then reduced the risk of fraud to a manageable level. The technology did so at the cost to the consumer of restricting the locations at which the money order could be cashed. American Express's innovation was to develop a technology which enabled it to sufficiently lower the risk of forgeries to permit it to broaden the network of locations at which the money order could be cashed without incurring losses. It did so by reducing the risk of fraud through characteristics of the document itself, eliminating the need for the second transmission of information which had made the postal money order secure.

Similarly, the development of the traveler's check reduced the chance of fraud in a letter of credit by eliminating the need for the bank officials' signatures to be on file in the receiving bank, by putting the authorization signature on the traveler's check itself via the requirement of two signatures by the customer. Moreover, by requiring customers to prepay for the traveler's checks (whose face value would be difficult to alter because of the use of preprinted values), American Express captured the "float" for itself. Finally, American Express transformed the potential dispute over a letter of credit into a smaller set of potential disputes. The only issues with respect to a travelers' check were the validity of the customers' signatures, something the technical specifications of the check itself made simple to verify, and the validity of the travelers' check itself, something that the technical specifications of the document also made easy to verify through counterfeitdefeating printing techniques. Letters of credit, on the other hand, were open to dispute as to the amount authorized, as well as the disputes possible with travelers' checks. Moreover, by transforming the travelers' check transaction from consumer-domestic bank-foreign bank-consumer into one of consumer-domestic bank-American Express-foreign bank-consumer, American Express inserted itself as a repeat player into every transaction involving a traveler's check, giving it leverage to control the terms of the banks' behavior and using its reputation to guarantee payment. ${ }^{70}$ Because individual domestic banks' pair-wise transactions with foreign banks were limited in number, the banks had not been able to exert such leverage. This enabled American Express to insist on conditions that minimized the opportunities for fraud.

More complex payment systems are ubiquitous, although often invisible to the average consumer who benefits from their use. Figure 1 summarizes some of the payment systems used in different contexts in the U.S. economy today.

70 See Perritt, supra note 53, at 19 (“American Express traveler's checks are accepted because the market trusts that American Express will remain solvent."). 


\section{FIGURE ONE}

\begin{tabular}{|c|c|c|c|}
\hline hisingest & $\begin{array}{l}\text { Factoring, } \\
\text { LOC, Asset } \\
\text { Lending }\end{array}$ & $\begin{array}{l}\text { b2c: } \\
\text { Private La- } \\
\text { bel, Fuel }\end{array}$ & $\begin{array}{l}\text { b2b: } \\
\text { Fuel, EDI } \\
\text { "terms" }\end{array}$ \\
\hline Consumpe & $\begin{array}{l}\text { LOC, Home } \\
\text { Mortgage, } \\
\text { etc. }\end{array}$ & $\begin{array}{l}\text { c2c: } \\
\text { PayPal, } \\
\text { IOU, } \\
\text { HSBC }\end{array}$ & $\begin{array}{l}\text { c2b: } \\
\text { Terms, IOU, } \\
\text { Private } \\
\text { Label }\end{array}$ \\
\hline $\begin{array}{l}\text { Thininctar } \\
\text { Instivition }\end{array}$ & $\begin{array}{l}\text { ACH, } \\
\text { FedWire, } \\
\text { Swift }\end{array}$ & $\begin{array}{l}\text { VISA, MC, } \\
\text { Amex, JCB, } \\
\text { etc. }\end{array}$ & $\begin{array}{l}\text { Purchasing } \\
\text { Card, etc. }\end{array}$ \\
\hline & Mingingial & Consuner & Bushers \\
\hline
\end{tabular}

Many payment systems described in the business-to-business and businessto-financial institution segments of Figure 1 also have a relatively long history. Letters of credit, for example, date to at least the fifteenth century ${ }^{71}$, and individually negotiated contracts ("terms") between businesses with repeated interactions have long existed. ${ }^{72}$ Payment systems may also develop as part of financial services. For example, businesses have for centuries monetized inventory and accounts receivables through transactions with financial institutions. ${ }^{73}$ Legal rules for such practices reduce transactions costs, making possible transactions that would otherwise not occur, but also introduce new potential for fraud by expanding the set of possible

71 See Edwin S. Hunt \& James M. MuRray, History of Business IN MEDIEVAL Europe, $1200-1550$ at 66 (1999).

72 For example, a trucking company might arrange an account system with a truck stop chain to allow its trucks to refuel without the necessity of the truck drivers making a payment, with the truck stop chain doing consolidated monthly billing for all fuel purchases.

73 These transactions are not typically thought of as a payment system because such transactions are limited to the business-financial institution relationship. As one of the earliest examples of payment system development, however, we think they deserve mention and fall within our definition. For example, a business with a capital need will have a financial institution purchase the business's accounts on a nonrecourse basis and provide "specific credits for the business and function as servicer on the accounts. Thus, traditional factoring is a nearly complete outsourcing of all of the credit functions of the originator. The outsourcing itself provides the source of value in a factoring transaction. Given the factor's expertise in credit determinations and the economies of scale produced by servicing accounts from a number of originators, the factor places a higher value on the accounts than does the originator." Christopher W. Frost, Asset Securitization and Corporate Risk Allocation, 72 TUL. L. REV. 101, 146 (1997). 
transactions. ${ }^{74}$ The demand for the financial service of monetizing inventories produced the legal rules, including the development of financial instruments that facilitated such practices.

The structure of payment systems can have important implications beyond particular transactions. For example, the introduction of credit cards dramatically changed consumer credit. Before credit cards, "most consumer loans were made on a secured, installment basis. Each time a consumer wanted to borrow money, he or she had to reapply to the bank and go through the application and approval process again." 75 With the shift to credit cards as a payment system came the transformation of most consumer debt into unsecured, revolving debt. ${ }^{76}$

A full scale survey of the development and spread of the increasingly varied payment systems in use is beyond the scope of this paper. The relevant points for our purposes are that (1) payment systems offer a bundle of services which include, but generally are not limited to, the transfer of value; (2) different systems offer different bundles of services and costs; and (3) different systems' bundles create different incentive structures for the participants in transactions with respect to the resolution of disputes.

Since World War II, card-based payment systems have expanded into the business-to-consumer relationship and, more recently, into the consumer-to-consumer relationship. Banks and merchants began issuing credit cards of various types in steadily increasing numbers until today's explosion of consumer credit and debit cards has filled our mailboxes with offers on an almost daily basis. ${ }^{77}$ Card-based payment systems increasingly substitute for other payment mechanisms (e.g. cash and checks) ${ }^{78}$ In the consumer-to-consumer market segment, PayPal offers payment systems with many of the features of card-based payment systems (although usually not including the physical card) that allow individuals to pay other individuals. ${ }^{79}$ Our focus is on card-based payment systems. These systems offer

74 American Express had a small commercial credit program built around providing credit based on inventory starting in the early twentieth century. See GROSSMAN, supra note 65, at 194 . The company later had a major fraud problem in connection with a "field warehousing" commercial credit inventory lending product, begun in the $1940 \mathrm{~s}$, when $\$ 150$ million in salad oil was discovered to be missing from a tank farm due to fraud. Id. at $248,318-327$. The company ultimately paid out $\$ 60$ million to settle claims related to that fraud. $I d$. at 327 .

75 AURIEMMA, supra note 5, at 3.

76 Id.

77 See Credit Card Offers Again Filling Mailboxes, 14 No. 14 CONSUMER B ANKR. NEWS (LRP) 2 (June 24,2004 ) (reporting that U.S. households received more than 1.2 billion direct mail credit card solicitations during the first three months of 2004).

78 See EVANS \& SCHMALENSEE, supra note 1, at 91 ("Payment cards are substitutes for cash, checks, and other means of exchange.").

79 As part of the dot-com expansion and later implosion, there were many companies providing a similar service to PayPal, including Citigroup-sponsored c2it and HSBC-sponsored Yahoo Direct. See Rogers, supra note 55, at 16 (discussing rapid change in e-payment systems). All of these companies offered person-to-person money transfer services, typically through email accounts. Unlike with plastic 
important lessons for dispute resolution generally because of their success in reducing costs in dispute resolution and in aligning the incentives of the parties. Ultimately, their approach facilitates inexpensive resolution of the disputes.

\section{B. The Structure of the Technologies}

The technologies of card-based payment systems have both differences and similarities across systems. Some of these technical structures affect the incentive structure of the dispute resolution systems. In this section we examine the technical structures for their influence on the successful features of the dispute resolution systems.

\section{Similarities Among Card-Based Payment Systems}

In all types of card-based payment systems, both buyers (consumers) and sellers (merchants) must agree to use the system. ${ }^{80}$ In addition, the system itself must cover its costs of operation. The system must therefore offer a bundle of services and fees that is attractive to both buyers and sellers, generates sufficient revenue to fund the system's operating costs, and be competitive with the alternatives.

Because there are two independent, distinct sets of customers with different (and often opposing) interests involved in card-based payment systems, an important feature of card-based payment systems is how they manage these conflicting interests, including whether they prevent either interest group from gaining an advantage in the system as a whole. ${ }^{81}$ More-

cards, the email account acts as the alternative token to the plastic card. Presumably, transfers through PayPal are completed to offset an underlying exchange of goods or services. In cases where the payment provider does not have any information about, and is not responsible for the goods and services delivered (like the basic PayPal case), these payments are usually referred to as Quasi-Cash. See ERIC Jackson, The Paypal Wars: Battles with eBay, the MEdia, the MafiA, and the Rest of PLANET EARTH 9 (2004) (describing market niche for PayPal).

80 See, e.g., Paymentech Merchant Application and Agreement, Terms and Conditions for Merchant Agreement, $\$ 1.3$ ("You agree to comply with all Association Rules and Operating Guide procedures, and with such other procedures as we may form time to time prescribe for the creation or transmission of Sales Data. We may modify or supplement the Operating Guide in order to comply with requirements imposed by the Association Rules.") and \$5 ("There may be a chargeback under any of the following circumstances, or as the Association Rules and operational requirements dictate from time to time. Consequently, additions and/or deletions to this list may occur.") (copy on file with authors).

81 David S. Evans, The Antitrust Economics of Multi-sided Platform Markets, 20 YALE J. REG. 325, 331 (2003) ("A fundamental insight of the theoretical research is that these businesses need to determine an optimal pricing structure-one that balances the relative demands of the multiple customer groups-as well as optimal pricing levels. That insight has implications for many other strategic variables. Empirical examination of these industries finds that key business decisions are driven by the need 
over, the competition of systems for both merchant and consumer accounts is critical to ensuring the fairness of the systems' features. We therefore describe the systems' operation from the point of view of both merchants and consumers.

To merchants, card issuers offer ${ }^{82}$ payment guaranteed against certain forms of loss, such as consumer bankruptcy; ${ }^{83}$ relief from the need to collect on accounts receivable; faster payment (referred to as reduced days outstanding); automatic deposit of receivables; ${ }^{84}$ receivable financing: ${ }^{85}$ consumer credit services; ${ }^{86}$ fraud identification tools; ${ }^{87}$ fraud prevention tools, such as card security features, ${ }^{88}$ advance commitment to adopt new technologies as mandated by the payment mechanism provider, thus creating

to get critical levels of multiple customer groups on board and to balance complementary customer communities.").

82 For an exhaustive analysis of the payment system options available to merchants, see Merchant Seek, Debit Card \& ATM Processing, available at http:/www.merchantseek.com/debitcard.htm (last visited on February 14, 2005); American Express, Online Merchant Services, available at http://home3.americanexpress.com/uk/merchant/manage/manage_default.asp?manage_body=learnOMS _body (last visited on February 22, 2005); John Burtzloff, Accepting Customer Payments, Entrepreneur.com, available at http://www.entrepreneur.com/article/0,4621,305819,00.htm (January 13, 2003).

83 EVANS \& SCHMALENSEE, supra note 1, at 31 ("payment cards provide a means of insuring against consumer defaults"). Insurance against consumer default is not a trivial benefit-approximately one third of VISA's issuer costs in the quarter ending 1996, for example, were due to fraud or uncollected bills to consumers, making net charge-offs the second largest expense for issuers after the cost of funds. Id. at 214 .

84 Automatic deposit of receivables can be a significant element of the value proposition to merchants with high volumes of sales. For example, on average, in 2004, Wal-Mart eamed approximately $\$ 29.2$ million in sales every hour. If the electronic payment systems did not exist, Wal-Mart would have to implement a significant cash logistics system, including physical transportation, security, and more. Hourly sales are estimated by dividing Wal-Mart's annual revenue of $\$ 256.3$ Billion, by 365 days per year, by 24 hours per day. This rough calculation works out to be $\$ 29.2$ million. Note that in peak volume hours, Wal-Mart is likely to have substantially larger hourly revenue. See Wal-Mart Annual Report (2004), http://www.walmartstores.com/Files/annualreport_2004.pdf.

85 EVANS \& SCHMALENSEE, supra note 1, at 5 (By taking charge cards, a merchant "makes a sale to someone who could not have paid cash and avoids having to offer financing.").

86 David S. Evans \& Richard Schmalensee, Economic Aspects of Payment Card Systems and Antitrust Policy Toward Joint Ventures, 63 ANTITRUST L.J. 861, 890 (1995) ("[T]he issuers provide merchants with credit services that increase consumer demand and that the merchant might otherwise have to provide. Issuers also guarantee payment by assuming the vast bulk of credit and fraud losses."); see also CHUTKOW, supra note 4, at 58 (describing how credit cards improved consumer finance options for banks and consumers); Id. at 61 (quoting Bank of America official that credit cards were a "natural extension" of consumer lending); AURIEMMA, supra note 5, at 8 ("merchant [using credit card] has none of the risks inherent in extending credit or accepting checks").

87 EVANS \& SCHMALENSEE, supra note 1, at 241 (describing VISA's "Cardholder Risk Identification System," which "uses computer neural network technology to predict the probability that a particular transaction is fraudulent and prompts the issuer to contact the cardholder if a certain threshold is exceeded.").

88 See infra notes 97 to 101. 
network externalities ${ }^{89}$ and avoiding first mover problems in technology adoption; ${ }^{90}$ some marketing information about cardholders using the system; access to desirable groups of customers; ${ }^{91}$ increased sales through increased credit; ${ }^{92}$ and dispute resolution services. ${ }^{93}$

Competition for merchant business ${ }^{94}$ drives merchant acquirers (including closed networks) to continually enhance the product they offer merchants, as well as compete on price and other terms. ${ }^{95}$ For example, the

89 "There is a network externality when the value existing users get from the network increases when another user joins the network." EVANS \& SCHMALENSEE, supra note 1, at 149.

90 Id. at 113 (associations "develop and encourage system-wide innovations in transaction processing").

91 Evans, supra note 81, at 353 ("There may be certain customers on one side of the marketRochet and Tirole refer to them as 'marquee buyers' - that are extremely valuable to customers on the other side of the market. The existence of marquee buyers tends to reduce the price to all buyers and increase it to sellers. For example, American Express has been able to charge a relatively high price to merchants as compared to other card brands, because merchants viewed the American Express business clientele as extremely attractive. Corporate expense clients were 'marquee' customers that allowed American Express to raise its prices to the other side of the market, merchants.") (citations omitted).

92 ChutKow, supra note 4, at 62; AURIEMMA, supra note 5, at 7.

93 Many of these enhancements are discussed in more detail in section III, entitled Dispute Resolution Systems, below.

94 See AURIEMMA, supra note 5, at 27, 32 (2nd ed. 1996) (noting "fierce competition" for merchant business). In the early 1990 s there were approximately 250 merchant acquirers, although the top twenty-five VISA and MasterCard merchant acquirers accounted for 79 percent of the total transaction volume. Evans \& Schmalensee, supra note 86 , at 866 . Today approximately 80 merchant acquirers account for 95 percent of the market in the United States. Lloyd Constantine, Remarks at 2 Sided Market Conference, Columbia University School of Law, May 23, 2005 (notes from conference on file with authors). In addition to the competition for merchants by networks, there is fierce competition for managing merchants' private label (or store brand) cards. See, e.g., W.A. Lee, Citi Challenging Leaders in Private-Label Cards, AMERICAN BANKer, Feb. 1, 2002, at 8 [2002 WL 4099786] (describing competition among processors and financial institutions for private label business).

95 This competition has been a feature of the marketplace almost since the beginning. For example, American Express initiated a cooperative advertising program in 1962 to win airline business, paying for airline ads that included a suggestion that passengers use their American Express card. See

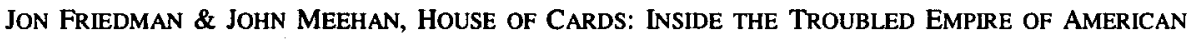
EXPRESS 59 (1992). Similarly banks used lower fees to persuade merchants to accept debit cards in the late 1980s. As Prof. Evans explains

[T]he debit card is an example in which different platforms made different pricing choices because they had different customers on board when they entered. In the late 1980s, ATM networks had a base of cardholders who used their cards to withdraw cash or obtain other services at ATMs. They had no merchants that took these cards. To add debit services to existing ATM cards, ATM networks charged a smaller interchange fee than did credit card systems to encourage merchants to install PIN pads. Compared to credit card systems' interchange fee of 38 cents on a typical $\$ 30$ transaction, ATM networks only charged 8 cents. (On debit and credit transactions, the interchange fee is paid by the merchant's bank to the cardholder's bank. A lower interchange fee will tend to lower prices on the merchant's side and to raise them on the cardholder's side.) The PIN pads merchants installed could read the ATM cards that cardholders already had and accept the PINs they used to access ATMs. In response to ATM networks' low interchange fee, many merchants invested in the PIN pads, whose numbers increased from 53,000 in 1990 to about 3.6 million in 2001 . In contrast to the credit card systems, which already had a base of merchants who took their cards and con- 
physical cards have changed over time to better prevent fraud. ${ }^{96}$ Thus, in the 1980s, the payment mechanism providers mandated the addition of the "Card Verification Value" numbers to the back of the card ("CVV1") and the magnetic strip ("CVV2"). ${ }^{97}$ The CVV numbers made it more difficult for a thief not in possession of the physical card to secure enough information to make a fraudulent purchase. ${ }^{98}$ For example, if a thief stole a credit card receipt from a consumer's trash, the thief would have the consumer's name as it appears on the card and the card number. ${ }^{99}$ He would not, however, have the CVV numbers, which are not printed anywhere on the receipt and should not be stored in any third party information system. ${ }^{100}$ In response, of course, criminals created more sophisticated methods of gaining card information. ${ }^{101}$

The appearance of these enhancements is important because merchants, not merchant acquirers or card issuers, bear the burden of paying for

sumers who used them, ATM systems had to persuade banks to issue debit cards and cardholders to take these cards. Their strategy worked: The number of VISA debit cards in circulation increased from 7.6 million in 1990 to about 117 million in 2001.

Evans, supra note 81, at 352-53 (citations omitted). Competition extends beyond large merchants. See, e.g., Steve Watkins, Nashville, Tennessee Small Merchants Provide Steady Business to Credit Card Processor, INVESTOR's BUSINESS DAILY, Jan. 28, 2004, at A07 (describing iPayment, Inc.'s strategy of focusing on small business accounts with an average annual charge volume under $\$ 250,000$ but with a total annual charge volume of $\$ 4$ billion).

96 See infra note 184.

97 ChuTKOw, supra note 4, at 188; id. at 194 (describing CVV system).

98 Homer Brickey, Credit Card Firms Battle Crooks with Technology, THE PATRIOT LEDGER, June 24, 1995, at 27 ("[t]he best deterrent so far is a separate number used in a card-verification system, usually three digits and based on a mathematical algorithm (formula) known only to the card issuer. 'That has really put a dent in fraud," said John McKnight, regional director of fraud control for VISA.).

99 Beginning in 2005, the associations bar merchants from printing the full card number on the receipt. See, e.g., MasterCard International Inc., Global Operations Bulleting No. 3, Mar. 1, 2005, at 88 ("Newly installed, replaced, or relocated point-of-interaction (POI) terminals, whether attended or unattended, must produce receipts that reflect only the last four digits of the primary account number (PAN). Fill characters such as $\mathrm{X},{ }^{*}$, or \# must replace all preceding digits.") (copy on file with authors); Global Payments, Inc. Card Account Information Truncation Requirements: Suppression of Account Information on Transaction Receipts, http:/www.globalpaymentsinc.com/myglobal/industry_initiatives/ card_trancation_requir.html (describing association rules). State governments created a variety of requirements on account number truncation, ultimately preempted by the Fair and Accurate Credit Transactions Act of 2003, Pub. L. 108-159, 117 Stat. 1952.

100 Another example is VISA's deployment of the "Payment Service 2000" in 1992, which required members to upgrade their processing capabilities. The "Payment Service 2000" increased VISA's competitiveness against MasterCard and American Express and also reduced fraud. EVANS \& SCHMALENSEE, supra note 1, at 204-05 (describing rollout of system).

101 Chutkow describes several of these methods. One example is the use of a separate reader in situations where the card is used out of sight of the cardholder (e.g. restaurants). The card is swiped through not only the point-of-sale terminal but a reader that captures the information from the card; this information is then used to create a fraudulent card that appears legitimate. Other schemes include the use of cameras to capture cardholders' entry of PIN numbers. CHUTKow, supra note 4, at 185-86. 
many types of fraud. ${ }^{102}$ Innovations to reduce those fraud costs borne by merchants do not directly benefit any of the parties in direct control of the payment system: merchant acquirers, issuers, or payment mechanism providers. However, card networks that offer superior fraud prevention measures such as CVV numbers have a competitive advantage in gaining merchant business. For example, if a new anti-fraud feature is introduced by American Express, merchant acquirers who process VISA and MasterCard transactions are at a competitive disadvantage in gaining both new accounts and transactions from their existing customers. ${ }^{103}$ Market forces have thus driven the merchant acquirers and payment mechanism providers to enhance consumers' cards for the benefit of both consumers and merchants, even though neither consumers nor merchants have a direct voice in the design and operation of the card-based payment systems, as we discuss below.

Merchant acquirers profit from their merchant accounts primarily through a variety of charges, including discount rate, ${ }^{104}$ equipment rental fees, membership fees, service fees, and dispute resolution-related fees. ${ }^{105}$ Fees differ substantially between institutions and between merchants. WalMart, for example, likely pays lower per transaction fees than most small merchants, because Wal-Mart's volume is substantially larger, giving it leverage in negotiations with a merchant acquirer that Joe's Deli lacks. ${ }^{106}$ Some merchant acquirers require equipment rentals, others allow merchants to purchase their own equipment. Most importantly for our purposes, merchant acquirers charge for various aspects of processing disputes.

102 Some types of fraud are paid for by the issuer bank. Thus when a card number is stolen and a counterfeit card is created, the issuing bank usually bears the loss. See id. at 186.

103 Recently, VISA introduced "Verified by Visa" and MasterCard introduced SecureCode. Both of these programs utilize an authentication technology to verify the cardholder's identity, at least verification of the registered identity on file with the issuer. When SecureCode authentication is offered by the merchant and merchant acquirer, the association rules shift liability for fraudulent transactions from the merchant to either the issuer or the cardholder. Although there are many flaws associated with these two programs, these two initiatives have made both VISA and MasterCard more attractive to certain merchants who suffer from high rates of fraud and chargebacks. The smartcard initiative (EMV) holds similar promise for certain kinds of fraud.

104 The discount rate includes an interchange fee that is passed from the merchant acquirer through the association to the issuer, to compensate the issuer for the float and certain cardholder risks. See MasterCard Intemational, MasterCard Dictionary, December 2003, Discount Rate, at 34; and Interchange, at 52-53. See also, ViSA U.S.A. INC. OPERATING REgulations, Volume I-GENERAL Rules, MAY 15, 2004, [hereinafter, VISA GENERAL RulES, Volume I], §A, Definitions, Interchange, at A-27. See also, MasterCard International, Quick Reference Booklet, October 2003 [hereinafter, MasterCard Quick Reference Booklet], §5, Interchange Rate and Other Fee Programs, page 5-1 (describing interchange generally).

105 See EVANS \& SCHMALENSEE, supra note 1, at 213 (describing various merchant fees).

106 Wal-Mart, for example, is estimated to do $10 \%$ of all PIN debit volume in the U.S. David Sibley, John Michael Stuart Centennial Professor in Economics, University of Texas in Austin, Presentation at the Columbia University School of Law Two-Sided Market Conference (May 23, 2005). 
For example, typical merchant acquirers in the United States charge merchants a discount rate of between $1.5 \%$ and $3 \%$ of the purchase price. ${ }^{107}$ Thus in a typical $\$ 100$ charge by a consumer, the merchant acquirer will pay to the merchant between $\$ 97$ and $\$ 98.50$ of the $\$ 100$, retaining $\$ 1.50$ to $\$ 3.00$ as its fee. The merchant acquirer will then have to forward the interchange fee to the payment mechanism provider, most of which is then passed along to the issuer. ${ }^{108}$ The interchange expense varies by the type of merchant, risk, and other factors. ${ }^{109}$

In addition to monetary charges, each network has its own system of rules governing everything from the physical attributes of cards ${ }^{10}$ to how disputes are handled. ${ }^{111}$ Merchants must adhere to the operating rules of the payment mechanism provider, through the terms of the contract between the merchant acquirer and the merchant. ${ }^{112}$ For example, the two leading associations (VISA and MasterCard) also require the merchant acquirer to have a merchant agreement with every merchant it services and to incorpo-

107 See MerchantSeek Merchant Account Rates, www.merchantseek.com/merchant_accounts _rates.htm (last visited April 23, 2005) ("a typical discount rate for U.S. businesses is right around $2.49 \%$... Non-US businesses will pay a higher discount rates [sic] closer to the $3 \%$ to $4 \%$ range.").

108 See Evans \& Schmalensee, supra note 86, at 890 ("both MasterCard and VISA have set interchange fees so that the payment goes from the merchant side to the issuer side."); Evans, Antitrust Economics, supra note 81, at 376 ("A higher interchange fee tends to raise merchant fees and lower cardholder fees."); Id. at 375 ("Charge card systems-such as Diners Club and, historically, American Express-set these fees so that merchants contributed the preponderance of fees.").

109 See Tim Miller, Explaining Credit Transaction Fees, ENTREPRENEUR.COM, Aug. 27, 2001, http://wwww.entrepreneur.com /article/0,4621,292172,00.html (last visited April 23, 2005) ("Discount rates vary depending on the type of business, such as traditional brick-and-mortar business, a mailorder/telephone-order business, a restaurant or an e-business. Discount rates also vary depending on whether a card number is keyed into the point-of-sale terminal or swiped into the terminal."). Historically, interchange was designed to compensate issuers for the guaranteed payment, float, and the costs of extending credit to consumers. More recently, merchants have argued that they are indirectly funding cards with substantial benefit programs, far beyond the original purposes of funding float and risk. See also MasterCard Quick Reference Booklet, supra note 103, § 5 (explaining various regional and product based interchange programs).

110 See VISA General Rules, Volume I, supra note 104, § 10. See also MASTERCARD INTERNATIONAL, CARD DESIGN STANDARDS (2003).

111 See VISA GENERAL RULES, VOLUME I, supra note 104, $\$ 7$ (description of the Dispute Resolution process, generally); MASTERCARd INTERNATIONAL, CHARGEBACK Guide (rev. June 2004) [hereinafter MASTERCARD CHARGEBACK GUIDE] (guide to Chargebacks); and VISA U.S.A. INC., OPERATING REgUlations: Volume II, DISPUTE RESOlution Rules (May 15, 2004) [hereinafter VISA GENERAL RULES, VOLUME II] (rules associated with Chargebacks and Dispute Resolution).

112 See, e.g., PAYMENTECH MERCHANT APPLICATION AND AGREEMENT, supra note 79, § 1.3 (Jan. 2004) (requiring the merchant "to comply with all Association Rules and Operating Guide procedures, and which such other procedures as [Paymentech] may from time to time prescribe for the creation or transmission of Sales Data."). See also VISA GENERAL RULES, VOLUME I, supra note 104 § 4.2.C (describing the minimum requirements of a Merchant Agreement between the Acquirer and the Association); MasterCard International, Bylaws and Rules, April 2004 [hereinafter, MasterCard Bylaws], § 9.1, (Apr. 2004) (description of the requirements for a Merchant Agreement and certain provisions). 
rate the terms and conditions of the operating rules into that merchant agreement. ${ }^{113}$

On the consumer side, the value proposition is itemized billing with delayed payment, referred to in the industry as "country club style billing"; 114 lifestyle financing (i.e. that you can consume a cruise today and pay for it over the next year) ${ }^{115}$ record keeping features, including summary statements and interfacing with personal finance software; ${ }^{116}$ fraud protection limiting losses to a small, fixed amount (imposed in some countries by government regulation); ${ }^{117}$ point schemes; mail-order and Internet purchasing; ${ }^{118}$ and dispute resolution processes. As on the merchant side, market forces have driven continual improvements in card features and contract terms that benefit consumers. For example, the practice of offering low introductory balance transfer interest rates to credit-worthy consumers has greatly lowered the cost of lifestyle financing for many, ${ }^{119}$ while the use of prepaid cards has extended the convenience of card usage and the availability of alternate dispute resolution to customers with less desirable credit ratings. ${ }^{120}$

Issuers are paid for the value they provide to consumers through charges that include annual membership fees, interest on balances, transac-

113 See Mastercard Bylaws, supra note 112, §§ 9.1.1-9.1.2; VISA GENERAL RULES, VoluME I, supra note $104, \S 4.2 . \mathrm{B} .1$.

114 AURIEMMA, supra note 5, at 7.

115 EVANS \& SCHMALENSEE, supra note 1, at xi ("The millions of people who finance purchases on credit cards want to enjoy life earlier than their current incomes and savings permit."); CHUTKOw, supra note 4, at 61 ("enormous financial flexibility" introduced by credit cards.); AURIEMMA, supra note 5, at 6 ("the convenience and credit availability offered by bank credit cards were major contributors to their proliferation around the country.").

116 AURIEMMA, supra note 5, at 7.

117 Id. ("Bank cards also offer a comparatively safe means for conducting transactions. If currency is lost or stolen, the potential loss is much greater than if a credit card is stolen. It is more difficult to fraudulently use a credit card, and the cardholder's liability is limited if a card is misused.").

118 Id.

119 See, e.g., Aviya Kushner, Proceed with caution on balance-transfer 'deals', Bankrate.com, Financial Literacy in America, http://www.bakrate.com/brm/news/financial-literacy2004/ balance-transferl .asp (last visited April 25, 2005) ("'If you're a good, responsible consumer, it can be a great opportunity,' says Mark Oleson, director of Iowa State University's Financial Counseling Clinic.").

120 The use of prepaid cards, also called Stored Value Cards, is limited to the value on the card. So, individuals who cannot secure credit may still avail themselves of the payment system, by depositing funds onto such a card. These prepaid cards are proliferating into new uses that are targeting the cash economy. For example, some employers are now putting the entire value of a paycheck onto a Payroll card, for those employees who lack a bank account. The employee may then spend their paycheck, simply by using the card at a merchant, or withdrawing funds at an ATM. See, e.g., Lavonne Kuykendall, Banks Taking Baby Steps in Prepaid Debit Space, AMERICAN BANkER, October 28, 2004, at 5 . 
tion fees (late fees, over limit fees, etc.). ${ }^{121}$ Issuers are also compensated by the merchant acquirers through the interchange fee. ${ }^{122}$ Many of these charges not only are subject to general competitive pressures-with banks competing, for example, to offer lower balance transfer costs to good potential customers-but also to individual negotiations between consumers and issuers. ${ }^{123}$ Issuers also receive payments from organizations offering cobranded cards (e.g. professional associations, alumni associations, and the like). ${ }^{124}$ Also as with merchant acquirers, the networks directly (closed networks) or indirectly (open networks) require consumers to agree to the relevant network rules, including the rules governing dispute resolution. ${ }^{25}$

All potential card users cannot bargain equally effectively with all card issuers. Consumers with better credit have greater bargaining power than those with poor credit scores. ${ }^{126}$ Consumers that are more profitable than others also have greater bargaining power. Profitable consumers may not be the ones with the best credit scores. ${ }^{127}$ As courts have recognized, however, the market provides many opportunities for consumers to obtain access to card-based payment systems. ${ }^{128}$ It is not necessary that all consumers have equal bargaining power for consumer-issuer bargaining to effect

121 EVANS \& SCHMALENSEE, supra note 1, at 147; AURIEMMA, supra note 5, at 26-27 (describing revenue sources for issuers).

122 EVANS \& SCHMALENSEE, supra note 86, at 890 (payment of the interchange by the merchant acquirer to the issuer "reflects the fact that, in both [the VISA and MasterCard] systems, other rules require the issuers to bear far more of the costs and to take much more of the risk of producing the venture's interdependent payment service.").

123 See, e.g., How to Negotiate a Better Credit Card Deal, http://www.ehow.com/ how_109504_negotiate-better-credit.html (last visited May 31, 2005) (describing how consumers can negotiate more favorable credit card deals.). Note that we would not expect to see identical products as consumers demand different cost structures depending on their circumstances. See also, EvaNS \& SCHMALENSEE, supra note 1, at 211 (distinguishing between fee structures preferred by those who pay off balances and those who carry balances).

124 AURIEMMA, supra note 5, at 12.

125 Issuers can modify the rules (including dispute resolution rules) even after the consumer has accepted the card's original terms in many states. See, e.g., Edelist v. MBNA America Bank, 790 A.2d 1249 (Del. 2001).

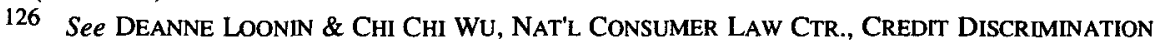
100 (3d ed. 2002) (describing credit scoring). Once card issuers solved the problem of screening card holders to restrict the pool to those with desirable credit behavior, the list itself becomes valuable. As a result of American Express's success in this regard, for example, the brokerage firm of Shearson Loeb Rhoades accepted a merger with American Express in part to gain access to "the master list of AmEx's Gold Card holders." FRIEDMAN \& MEEHAN, supra note 95, at 103.

127 See Frontline: Secret History of the Credit Card (PBS television broadcast, Nov. 23, 2004), available at http://www.pbs.org/wgbh/pages/frontline/shows/credit (last visited February 24, 2005).

128 See, e.g., Johnson v. Chase Manhattan Bank, 231 N.Y.L.J. 19 (N.Y.Sup. Ct. March 11, 2004) (noting that "In any event, in this day and age when credit cards are rather easily available from any of a number of issuers, the fact that the customer who elected not to accept the [modification to the account agreement initiated by the issuer] would have to terminate his/her account, would not be grounds for concern."). 
the terms of issuer-consumer contracts; what is important is the marginal consumer's ability to bargain. In the highly competitive issuer market, ${ }^{129}$ this ensures that issuers continue to innovate to attract high value consumers as customers. These innovations then spread throughout the industry.

\section{Key Differences Among Card-Based Payment Systems}

There are two dimensions in which card-based systems differ from one another that are important for our analysis: network structure and payment timing. With respect to network structure, there are open and closed systems; these differ in the ownership and management of the relationships between the financial institutions ${ }^{130}$ and the consumers and merchants. The entity maintaining the contractual relationship with the consumer is known as the "issuer" and the entity with the contractual relationship with the merchant is known as the "merchant acquirer" or "acquirer." An open system is a payment system where an association or third-party company maintains a contractual relationship with both the card issuer and the merchant acquirer. In an open system, issuers and acquirers may enter and exit that particular payment system according to the terms and conditions of membership. ${ }^{131}$ Only the issuer maintains a direct contractual relationship with the consumer cardholder, and only the acquirer maintains a direct contractual relationship with the merchant. Open systems include associations such as VISA and MasterCard. ${ }^{132}$ In a closed system, on the other hand, the issuer and the acquirer are the same financial institution; one entity main-

129 In the early 1990s there were approximately 7,300 VISA issuers, including approximately 100 national issuers such as Capital One, Citibank, MBNA, Bank of America, Household Bank (HSBC), US Bank, and others, who issue cards across the United States. Evans \& Schmalensee, supra note 86, at 865-66.

130 We use the term "financial institution" to describe entities issuing cards, although not all such entities meet the federal regulatory definitions of the term. See, e.g., 15 U.S.C. $\$ 6809$ (3)(a) (defining financial institution as "as a business engaging in financial activities). Two major open card associations limit their membership to financial institutions who are licensed for financial activity (i.e., lending, deposit taking, etc.) in the country which they operate. See MasterCard Bylaws, supra note 112, art. I, $\S$ 1; VISA General RULES, Volume I, supra note 104, art. II, $\$ 2.01$.

131 There are terms and conditions for entry and exit into each payment system, and these conditions include fees and capitalization requirements. Entry into the MasterCard association may require a member initiation fee, a transfer fee, a sponsorship fee, and/or a portfolio acquisition fee. See MasterCard Bylaws, supra note 112, \$ 2.12. See also EVANS \& SCHMALENSEE, supra note 1, at 233 (describing exit terms).

132 Some industry leaders assert that associations such as VISA are not "open" because membership is limited to financial institutions. Non-banks are not permitted to become a member. See supra note 130 . The assertion that such associations are not open was recently made by Randy Gutierrez of Unicache at the Technology of Remittances Conference in San Francisco on December 11, 2004. For the purposes of this paper, we need not address this particular point in our analysis since the point is that the systems are open to entry and exit by multiple financial institutions, creating competitive pressures. 
tains the relationship with both the cardholder and the merchant. Closed systems include programs such as department store cards, American Express, ${ }^{133}$ and Discover. As we will discuss below, the incentive structures for various parties are different in open and closed systems.

With respect to payment timing, there are credit and debit cards. A credit card is a short term extension of credit by the issuer to the consumer. ${ }^{134}$ The consumer is not obligated to immediately pay the full balance at the end of the month. If the consumer does pay the full balance owed, no interest is charged. ${ }^{135}$ With a debit card, on the other hand, the money to pay the merchant is immediately ${ }^{136}$ deducted from the consumer's bank account. Debit cards are expanding rapidly along with other cash-like substitutes, including prepaid and stored value debit cards where the consumer deposits cash and uses the card until the balance is zero. ${ }^{137}$ As discussed below, different regulatory structures apply to debit and credit cards, influencing a number of attributes of the payment system. For example, the

133 Historically, American Express maintained an exclusive relationship with both the cardholder and merchant (a closed system). Internationally, American Express selectively issued cards under unaffiliated financial institutions. Domestically in the United States, this historical structure may be changing, as American Express recently offered a co-branded cards with MBNA and Citibank. See MBNA Issues New American-Express Card Branded Credit Cards for More than 1,000 Affinity Groups [hereinafter American-Express Card Branded Credit Cards], http://home3.americanexpress.com/ corp//pc/2004/mbna_cards.asp (Last visited February 22, 2005). In this sense, American Express is moving from a closed system where it maintained the relationship with both the cardholder and merchant, to an open system, where it maintains a relationship with an issuer financial institution, who in tum maintains the relationship with the consumer.

134 AURIEMMA, supra note 5, at 2 ("Bank credit cards are a form of consumer loan, a revolving credit account that has a credit line of a specific amount that can be borrowed against in part or in full.").

135 For example, if a consumer has a zero balance on January 1, charges $\$ 10$ on January 15 , receives his statement for $\$ 10$ on January 20 , and pays the $\$ 10$ balance before the due date (usually 30 days later), no interest applies. If, however, the consumer has a $\$ 5$ balance on January 1 , and the card charges a $1 \%$ per month interest rate, and then charges $\$ 10$ on January 15 , the consumer will owe the $1 \%$ interest on the $\$ 15$. (This ignores the average daily balance method of calculating interest to simplify the example.) If the consumer charges an additional $\$ 10$ on February 15 and pays the $\$ 15$ balance in full by the due date, the consumer will still be charged interest on the February $15 \$ 10$ charge on the February statement. In short, the 30 day interest-free period applies only when the bills are paid completely and on time each month. See EVANS \& SCHMALENSEE, supra note 1, at 141-44 (detailing differences between methods of calculating interest).

136 Generally within minutes but, depending on the technology used, it may take longer. When a PIN is used, the deduction is instantaneous. When the debit card is swiped like a credit card, it will take up to two days. See EVANS \& SCHMALENSEE, supra note 1, at 299-300.

137 Stored Value cards, prepaid cards, and the like, are not regulated as depository accounts. See F.D.I.C. Gen. Couns. Op. No. 8 (1996), 61 Fed. Reg. 40490 (Aug. 2, 1996). See also F.D.I.C., Definition of "Deposit"; Stored Value Cards, 12 C.F.R. pt. 303, RIN 3064-AC80 (Apr. 26, 2004), available at http://www.fdic.gov/news/financial/2004/fil4404a.html (last viewed Sept. 23, 2005). For an interesting holiday shopping scenario where a family utilizes these forms of debit cards, see John Gould, Ready to Explode, http://www.intelcard.com/factsandfigures/03factsandfig.asp?A_ID=339 (last visited December 2004). A thorough account of legal issues involving stored value cards is Effross, supra note 62. 
money flows from the consumer into the transaction pipeline more quickly than in a credit card transaction.

\section{Networks}

In addition to the card-based payment systems' differences, there are differences among transactions within the system. These differences depend upon the relationships between participants in the systems which are based on the type of network used to process the transaction. There are three types of networks over which these transactions travel: centralized, noncentralized, and hybrid. In a noncentralized network (see Figure 2), each bank has a connection to every other bank in the network. ${ }^{138}$

\section{FIGURE TWO}

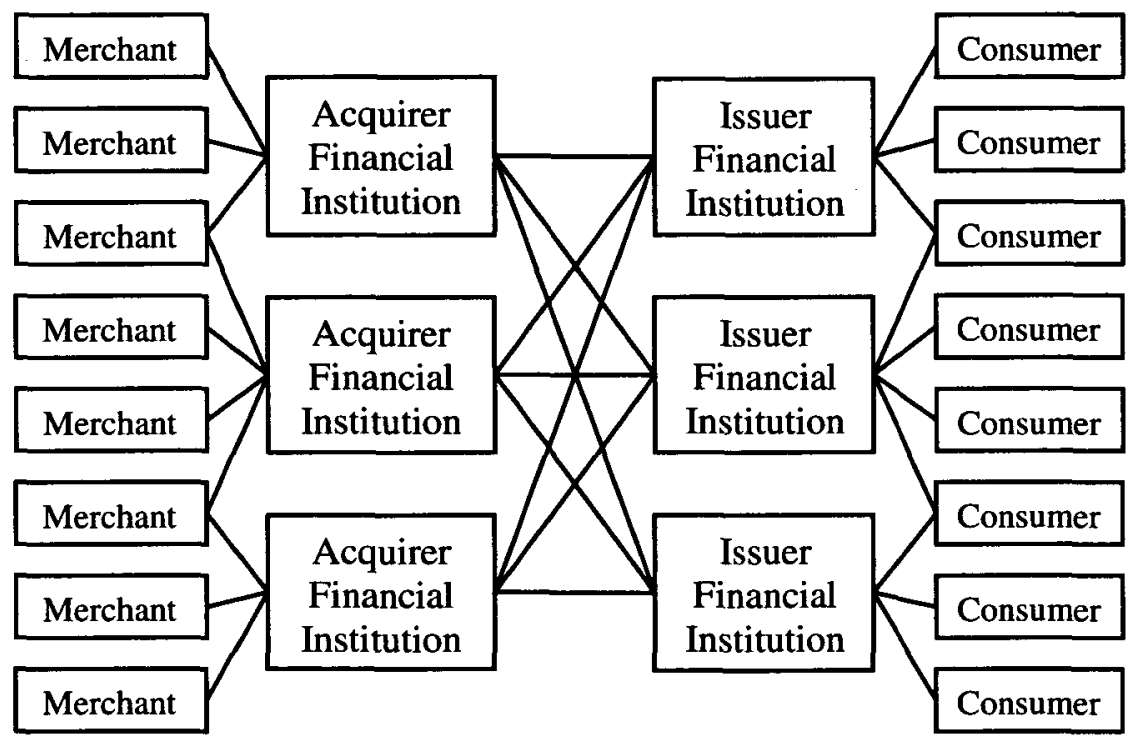

Banks used noncentralized networks when they first began issuing cardbased payment systems, with each bank contracting individually with other banks for the acceptance of the issuing bank's cards at the merchant acquirer banks' merchants. Thus, when a consumer used a decentralized net-

138 Historically, when banks privately issued their own banknotes, the settlements between them occurred through individual, bilateral exchanges of each others' notes. See Neal Stephenson, The Great Simoleon Caper (Spring 1995), http://www.cyberartsweb.org/cpace/scifi/cyberbib/Essays/ SimoleonCaper.htm (last visited February 9, 2005) (explaining in detail how currency works through a fictional account of creation of private currency). 
work card issued by Chase at a merchant acquired by Key Bank, the authorization and payment transactions would be routed through a private network between Chase and Key Bank. If the consumer later used the card at a merchant acquired by Wells Fargo, the transactions associated with that purchase would be routed through a private network between Chase and Wells Fargo. Similarly, if a different consumer used a card issued by Bank of America at the merchant acquired by Key Bank, those transactions would be routed through a third private network between Key Bank and Bank of America. ${ }^{139}$ As the number of merchant acquirers and issuers contracting with each other grew, the number of private networks needed to make the noncentralized network function grew rapidly. (See Figure 2). Today, such bilateral agreements may be prohibited, at least in certain contexts, such as the processing and routing of transactions. ${ }^{140}$

In a centralized network, on the other hand, all contracts and transactions are with a central authority (e.g. VISA). (See Figure 3 ). The centralized networks offer significant cost savings to the participating institutions. Rather than individually negotiating contracts and maintaining infrastructure to support the flow of money and information between every pair of entities in the network, a participating institution has to comply with only one set of technical standards for the exchange of money and information, and negotiate only one set of contracts with the central entity.

The availability of hybrid and private networks limit the monopoly power of the payment mechanism providers both directly (in the case of open systems) and indirectly (via open systems' competition with closed systems) by allowing participants to route transactions outside any particular associations or network providers' system. It is necessary to consider how transactions are processed to fully understand this point.

When a consumer presents a card to a merchant and the merchant swipes the card through the point of sale terminal, the terminal reads various information from the card. ${ }^{141}$ That creates an authorization transaction which is forwarded to the merchant acquirer's system. There, the authorization transaction is routed according to rules based on the bank identification number ("BIN") from the consumer's card. This number identifies the financial institution that issued the card and the appropriate 'routing,' to the merchant and merchant acquirer. The routing is the path the authorization transaction takes from this point to reach the issuer. It is dependent on the

139 The dispute resolution processes, described below, would function differently under a bilateral processing approach. See discussion infra Section III, Dispute Resolution Systems.

140 See MasterCard International, Cirrus Worldwide Operating Rules, June 2004, \$9, Processing Requirements (for a rule requiring certain cash machine transactions to be routed through MasterCard, having the effect of prohibiting certain bilateral processing agreements). See also MasterCard International, Maestro Global Rules, July 2004, \$9; Steve Ruwe, Required Processing of Visa Transactions through VisaNet, Visa Bus. Rev., Visa U.S.A., Feb. 2005.

141 Terminals were introduced in the early 1980s. CHUTKOw, supra note 4, at 164-65 (describing introduction of the point of sale terminals). 
contracts and rules of the participating institutions. For example, consider the case of a pure centralized network, such as VISA, with a consumer card issued by Chase and a merchant acquired by Fifth Third Bank. A VISA card issued by Chase and used for a charge submitted through a merchant acquired by Fifth Third Bank will have the authorization transaction routed from the merchant to Fifth Third Bank, then to VISA, then to Chase, and then the approval or rejection will reverse the path back to the merchant. The payment transaction follows the same path later that day from Chase back to the merchant's account with Fifth Third Bank. Payment by the consumer to Chase follows at a later date.

\section{FIGURE THREE}

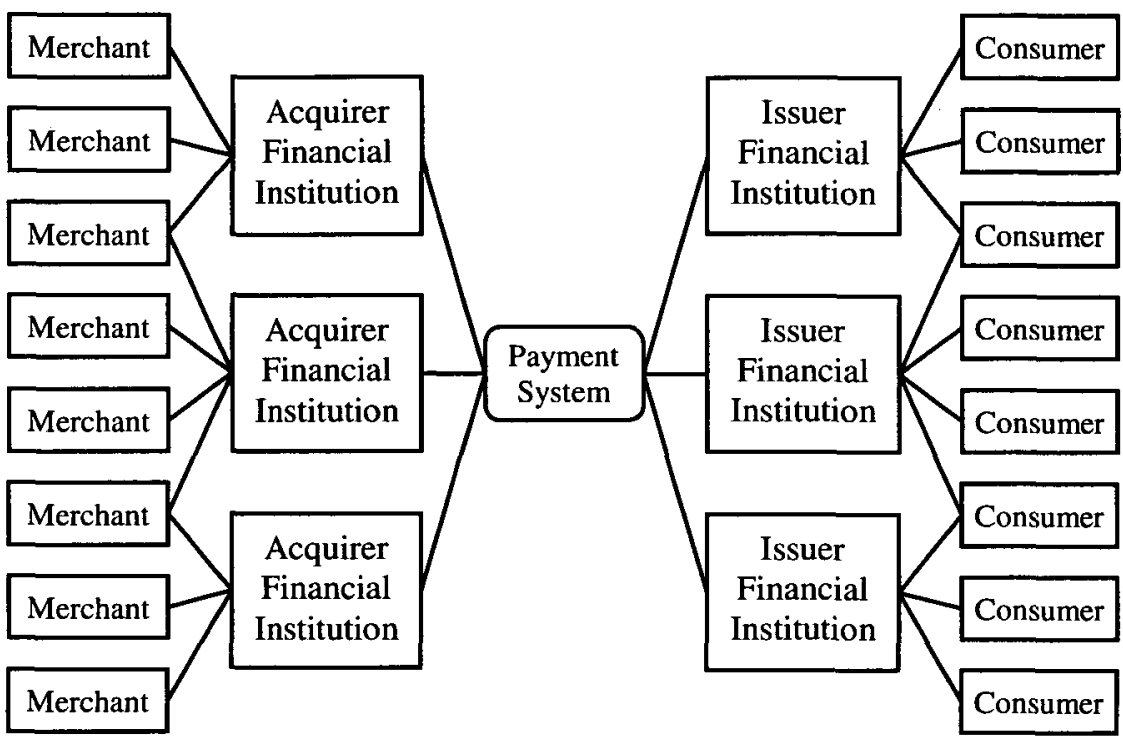

Hybrid networks occur when an institution participating in a centralized network shifts some of its transactions from the network to a bilateral arrangement with another institution in the network, bypassing the central system for a subset of transactions. For example, Chase might determine that a large number of cardholder transactions occur with merchants in Athens, Greece acquired by the General Bank of Greece. ${ }^{142}$ By negotiating a separate contract with General Bank of Greece and building the necessary infrastructure, including dedicated communications links, General Bank of Greece can dynamically route transactions involving Chase customers outside of the VISA network over a private network between General Bank of

142 We have chosen actual bank names for our examples. The transactions described, however, are all hypothetical. 
Greece and Chase. To do this, General Bank of Greece programs its computer to route transactions with Chase BINs directly to Chase rather than through the VISA network. ${ }^{143}$ Chase and General Bank of Greece can then divide the savings from shifting those transactions away from the VISA network among themselves. ${ }^{144}$ Although at present most of such agreements are between banks in different countries, because the savings from removing transactions from the network are greater when the network for charge for currency conversions is also present, there is no reason why such hybrid networks cannot exist domestically as well. ${ }^{145}$

Centralized networks benefit from the network externalities and transaction cost-saving features of centralization. There is thus a strong incentive for institutions to join centralized networks as networks grow in size and complexity. This incentive creates fears about monopoly abuses by the networks. ${ }^{146}$ At least while financial institutions are not restricted in routing transactions across any network (of which that financial institution is a member), monopoly rents the network can obtain are limited by the potential competition allowed by hybridization of the network. ${ }^{147}$ If the network abuses its position, ${ }^{148}$ institutions will shift more business outside the network. Furthermore, most financial institutions are members of both VISA and MasterCard. ${ }^{149}$ So, even in environments that restrict dynamic transac-

143 For example, the BIN table will direct that all card transactions prefixed with VISA BINS are routed to the VISA connection except BINs belonging to Chase, which are routed through the special connection.

144 At times, networks have attempted to prevent this by charging a fee regardless of whether the network was used. For example, Interlink attempted to impose such a charge in the debit card market but was forced by competition from Mastercard's Maestro network to drop it. See Balto, supra note 63, at 1096-97.

145 Such networks do exist for ATM/debit cards, where the merchant may route the transaction based on the cost of using a particular network. See EVANS \& SCHMALENSEE, supra note 1, at 310. See also Ruwe, supra note 140 (notice that, with some exceptions, domestic Visa branded transactions must be processed through VisaNet, effectively prohibiting domestic bilateral transaction routing arrangements).

146 See Randy E. Barnett, Pursuing Justice in a Free Society, Part One: Power vs. Liberty, CRIM. JUST. ETHICS, Summer/Fall 1985; Randy E. Bamett, Pursuing Justice in a Free Society, Part Two: Crime Prevention and the Legal Order, CRIM. JUST. ETHICS, Winter/Spring 1986 (discussing problem of monopolizing entity in a competitive legal market).

147 Payment card system networks are vulnerable to competition. As Professors Evans and Schmalensee note,

In network industries, as in industries with important scale or learning economies, we also tend to see temporary dominance of one or a few firms or networks. There is a temptation to think that such dominance will be permanent. But most network industries are not like manufacturing industries, in which ownership of capital-intensive capacity or key proprietary technology may give rise to long-lived dominance. As we shall see, the shares of payment card networks and individual issuers have varied considerably over time.

EVANS \& SCHMALENSEE, PAYING, supra note 1, at 153.

148 We define "abuse" as seeking to obtain profits above the competitive level.

149 Since many financial institutions are members (owners) of both MasterCard and Visa, the charge is often made that these two associations must be directly colluding together. See EVANS \& 
tion rerouting among competing networks, financial institutions are able to threaten to, or to actually alter their portfolios of cards to prevent either network or both from extracting monopoly rents. Even financial institutions that are only a member of either VISA or MasterCard may be able to issue cards under other payment brands, such as American Express. ${ }^{150}$ Moreover, because the network is negotiating with the issuers and merchant acquirers, who are themselves in a competitive market for consumer and merchant accounts, the network's ability to shift costs to individual consumers or merchants is limited by the market pressures in the issuer and merchant acquirer markets. In effect, consumers and merchants negotiate with the network through the issuers and merchant acquirers. Those institutions can be thought of as "bundling" individual consumer and merchant bargaining power into larger units, since an issuer or merchant acquirer which negotiates more favorable terms for its customers from the network will gain a competitive advantage over other institutions. Competitive pressures from the individual account market thus are an important limit on the ability of networks to rent-seek at the expense of merchants or cardholders.

\section{Applying the Technology: The Payment Transaction}

A payment transaction in a card-based payment system has two logical components: the authorization and the settlement transactions. ${ }^{151}$ In a sim-

SCHMALENSEE, supra note 1, at 193-06 (debunking this claim). Some countries, such as Canada, address this concern head-on by prohibiting a financial institution from issuing under both the MasterCard and Visa brands. See David A. Balto, Networks and Exclusivity: Antitrust Analysis to Promote Network Competition, 7 GeO. MASON L. REv. 523, 538 (1999) (describing Canadian ban on duality). We have not found any study that addresses whether prohibiting an institution from issuing multiple brands either limits or promotes competition. If anything, we suspect that such limitations on card issuing, bilateral processing arrangements, or dynamic re-routing of card transactions, increase the transactions costs of switching from one association to another. This increase in switching costs correspondingly increases the monopoly-like rents that both associations may assess, to just below the amount required to change the card portfolio from one association to another.

150 See American-Express Card Branded Credit Cards, supra note 133, at 38.

151 In a credit-card transaction, those two components occur separately (referred to as a "dual message transaction"); in a debit card transaction those two components occur simultaneously (a "single message transaction."). The difference between single message and dual message approaches to payments creates potential issues for financial institutions. These issues are not relevant for the private dispute resolution mechanism, and, therefore, are ignored here. Also, the electronic path the transaction components take will vary depending on the type of network (open or closed) and the relationships between the particular banks and other parties. General descriptions of the payment card industry are contained in the opinions of the courts in U.S. v. VISA, U.S.A. Inc., 163 F.Supp. 322 (S.D.N.Y. 2001) and Schwartz v. VISA International Corp., 2003 WL 1870370 (Cal. Super. 2005). Although we disagree with the courts' legal reasoning and conclusions in these cases, the basic presentation of the technical details of the card systems is reasonably accurate. 
ple closed network transaction, a consumer uses her American Express card at Best Buy. The card is swiped at the Best Buy cash register, the card reader transmits the authorization request ${ }^{152}$ to American Express, and American Express checks the consumer's credit and responds accordingly. If the transaction is approved, the consumer signs for her purchase and the sale is complete. Later that day, ${ }^{153}$ the merchant uploads all its American Express sales transactions for the day to American Express. American Express posts the purchase to the consumer's account and transfers the funds to the merchant's account. At the end of the billing cycle, the consumer receives and pays her bill from American Express, but the funds (net of American Express's charges) have previously been sent to the merchant by American Express, a short term extension of credit to the consumer by American Express.

In an open system where the merchant acquirer and issuer institutions are different, the transaction is similar, except that the authorization transaction flows from the merchant to its merchant acquirer, then to the appropriate association, ${ }^{154}$ which routes the transaction to the issuer, who then responds via the same route. The settlement transaction flows later that day in reverse through this same route.

What appears to be an open network transaction can actually be a closed network transaction when the issuer and merchant acquirer institutions are the same. Thus, if a Citibank MasterCard is used to purchase a cellular phone at a Cingular store and Cingular's merchant acquirer is also Citibank, then the transaction may not be routed through the association but instead be handled internally by Citibank entirely within a Citibank network in the same manner as American Express would have handled the transaction if the American Express card had been used. ${ }^{155}$ When a transaction is internally routed, the incentive structures for dispute resolution change, as described below.

152 The data sent are the card number, expiration date, amount of transaction, date of transaction, security code, and merchant number. Some transactions also include additional security information such as cardholder addresses (e.g. Internet transactions).

153 There are generally several windows each day in which transactions are posted. Large merchants (e.g. Wal-Mart) may settle transactions multiple times within a day; smaller merchants may settle once a day.

154 In international transactions, there is an additional step in which the information flows between the appropriate national associations. Thus, when a U.S. consumer uses a U.S. issued VISA card in Europe, Visa Europe (a distinct legal and business entity) will pass the information from the European merchant acquirer to Visa U.S.A, who in turn will pass the transaction on to the US issuer. Interregional transaction handoffs occur when the region (within a single association) utilizes its own transaction authorization and settlement systems.

155 Of course, there may be differences in internal procedures between banks and other institutions. Our point is merely that the open network will resemble a closed network in these instances. When a transaction in an Open network is internally routed, the decision making incentives associated with dispute resolution more closely resemble the incentive structure of a Closed network. See discussion infra Section III, Dispute Resolution Systems. 
Further, some institutions subcontract data services with third party transaction processors. The rise of third-party entities was an important development in the 1990s. ${ }^{156}$ First Data, Total Systems, eFunds, EDS, Atos Origin, Alliance Data Systems, Sema, Arksys, FiServe, Euronet, and other companies contract with financial institutions to handle various aspects of processing card transactions. ${ }^{157}$ If the same company has contracted with both the merchant acquirer and issuer, the transaction may not be routed through the association, but stay entirely within the third party transaction processor's network. ${ }^{158}$

These differences can have consequences for the dispute resolution process, since a transaction that is not routed through the association is not necessarily governed by the association's rules; ${ }^{159}$ indeed, the association is likely to be completely unaware that the transaction even exists. When a transaction is routed outside the association, the institution(s) involved may opt to provide its (their) own dispute resolution process. ${ }^{160}$ This process substitution may be indistinguishable to the merchant and the cardholder

156 Brian G. Olsen, Bank Credit Card Organization, in AMERICAN BANKERS AssociATION, THE BANK CREDIT CARD Business 15, 22 (2d ed. 1996).

157 Third party transaction processing companies provide technology services to the financial institution. In effect, the financial institution is outsourcing their financial operations to that technology company. First Data began as a regional association of banks to handle processing. It was later spun off and became a for-profit company. Id. at 21 .

158 This routing alternative is an issue in that it juxtaposes the legal and technology relationships between associations and financial institutions. Some associations contend that not routing the transaction through the association will violate association rules. It certainly deprives the association of its fee for the transaction. This ability to reroute transactions can give large players with merchant and consumer accounts an advantage. See EVANS \& SCHMALENSEE, supra note 1, at 276 (describing how National Bancard Corporation saw this as a threat in Chicago in competition with First Chicago, which the company argued could undercut its price because it did not have to pay the interchange fee on transactions between merchant customers and its own bank card holders.) Evans \& Schmalensee argue that this does not necessarily advantage the First Chicago-type banks, because they still must cover the network costs on their own network. Id. at 277 . While they are correct, they do not take account of the function of such competition in limiting the interchange fee that the associations can charge. See, also, VISA's announcement that $\underline{\text { all }}$ signature debit transactions must be routed through VISA's network. See, e.g., Steve Ruwe, Required Processing of Visa Transactions through VisaNet, Visa Business Review, Visa U.S.A., February 2005, Issue No. 050215 (explaining that the Visa U.S.A Board of Directors has directed Visa U.S.A to revise its Operating Regulations to require all Visa transactions be processed through VisaNet).

159 The multi-party nature of the payment system creates disagreements about which party owns, manages, and regulates cardholder data, merchant data, and transactional data. See Paul Wenske, Some Debit Card Users Receive a Little More Protection, KANSAS CrTY STAR, Jan. 6, 2005, at Cl, available at http://www.kansascity/business/10575372.htm?lc (noting VISA chargeback protection is provided only on VISA's network.).

160 The motivation for routing around the association is the savings of the association's fees and expenses associated with the transaction. In the intemational context, the process, earnings, and expenses related to converting transacting currency into cardholder currency (also known as foreign exchange) can be a substantial motivation for routing around the association. 
from the association process, but it need not be. Regardless, the parties to the transaction are unlikely to know the corporate jurisdiction to which they are committed at the time of the transaction. ${ }^{161}$ And, the cardholder is unlikely to be aware of the differences ex ante because cardholders rarely know who a merchant's merchant acquirer is when making a purchase. ${ }^{162}$ Similarly, the merchant's employee conducting the transaction may be aware of the name of the consumer's issuer (which is generally imprinted on the card) $)^{163}$ but store clerks are unlikely to be aware of the consequences for fees or dispute resolution rules of accepting one card over another. No party to a particular transaction may thus be aware simply by entering into the transaction of either the specific legal rules to which they are agreeing to use in the event of a dispute, or the private jurisdiction that will apply those rules. Despite consumers' ignorance of the system, however, they are not disadvantaged because of the competition among issuers and networks.

ATM network transactions are similar with one key difference. In an ATM transaction, the interchange fees flow in reverse. Fees are paid by the issuer to the ATM owner, instead of by the merchant acquirer to the issuer. ${ }^{164}$ As with credit and debit card transactions, if a cardholder uses a machine owned by the issuer, the transaction is probably handled internally; if the cardholder uses a machine owned by another party, then the transaction flows over a network. Depending on the relationships between the ATM owner and the issuer, a transaction may flow through an association or through an alternative network, as described above. There are more alternative networks for ATM machines than for credit and debit card transactions at merchants. ${ }^{165}$ Indeed, most debit cards provide debit services

161 A similar issue arises with debit cards, where consumers may not be aware of whether they are using an online or offline system. See, e.g., Effross, supra note 62, at 362. Some commentators argue that such lack of knowledge is a justification for intervention. See, e.g., Malla Pollack, Opt-In Government: Using the Internet to Empower Choice-Privacy Application, 50 CATH. U. L. REV. 653, 670 (2001) ("Market choice activation of the 'invisible hand' requires transparency. Consumers cannot choose $x$ unless they can tell when $x$ is, and is not, part of the offer.").

162 Even if provided with this information, however, consumers may not be aware of the consequences of using particular financial associations with a merchant.

163 Many issuers use multiple brands on their cards, however. Thus AT\&T credit cards are currently issued by Citibank. Jane Adler, Troubles for Cobranded Cards, CREDIT CARD MGMT., Jan. 2005, at 12,14, 2005 WLNR 58777. The Citibank name appears only in small print on the back of the card, where it is unlikely to be noticed by the merchant's employee.

164 Fees flow in reverse because the ATM machine is a substitute for a branch of a financial institution. Therefore, when an issuer's cardholder utilizes another financial institution's ATM machine, the Issuer compensates that other financial institution for making their ATM available to their cardholders. Also, there is a cost for holding cash in an ATM machine. Thus, the interchange flows in the opposite direction for ATM transactions, from the Issuer to the Acquirer. Reverse interchange does create some unusual incentives for merchants, with regards to merchant ownership and placement of the ATM within the merchant's location.

165 For example, major ATM networks include NYCE, Star, Pulse, MAC, and MoneyStation. 
across several platforms. ${ }^{166} \mathrm{~A}$ bank, for example, may issue a debit card that works in its own ATM network, through a regional ATM network, and through MasterCard or VISA. ${ }^{167}$

Again, the crucial characteristic is the ease with which existing or new institutions can enter the market. Establishing a new connection between a merchant acquirer and an issuer requires only negotiation of an agreement between the institutions, acquisition of telecommunications channels, and modification of the relevant computer programs that route transactions. Although such costs are not zero, ${ }^{168}$ for large numbers of transactions the per transaction cost is effectively or close to zero, given the low marginal cost of telecommunications and the ability to amortize the fixed costs over substantial numbers of transactions. ${ }^{169}$ This ease of entry allows both actual $^{170}$ and potential competition ${ }^{171}$ to discipline the networks' behavior to-

166 See EVANS \& SCHMALENSEE, supra note 1, at 297.

167 During the 1980s, ATM networks became more interconnected. EVANS \& SCHMALENSEE, supra note 1, at 303 ("In the 1980s, ATMs not only increased in number, they became more interconnected."); CHUTKOW, supra note 4, at 231-32 (describing expansion of ATM networks). Some transaction processors such as First Data have purchased networks such as Star, which in effect makes First Data capable of internally routing transactions amongst their transaction processing customers without using the VISA, MasterCard or other traditional card-based system networks, a practice sometimes called sub-switching. Richard Mitchell, The Future of Visa and MasterCard, CREDIT CARD MGMT., June 2004, at 36, 38, 2004 WLNR 205830 ("First Data sought to leverage its connections with issuers and acquirers to create a closed-loop processing system, and enable clients that send V[ISA] transactions through First Data Net to bypass V[ISA]'s VisaNet authorization, clearing and settlement system and avoid some of the association's fees."). VISA initially saw the ATM networks as a threat. See CHUTKOW, supra note 4, at 231-32 (describing opposition from VISA to development of member bank ATM networks). The practice is recognized as a serious threat to the associations in the industry. Mitchell, supra, at 40 ("[T]he ability of First Data to route transactions internally as 'on-us' between its processing clients that are both issuers and acquirers not only is financially attractive, but theoretically allows the processor to provide customized loyalty programs, special pricing outside of 'inflexible' interchange schemes and other innovations not generally available through traditional networks.").

168 Determining the price structure for a multisided network such as a card-based payment system is a complex problem, whose solution can be costly. However new entrants have the benefit of existing price structures, which can serve as a model for the new entrant. See Evans, supra note 81, at 363 ("Multi-sided platform markets are also hard to get into because firms must solve quite complex business problems. That complexity may, however, give subsequent entrants an advantage; they can look to the pricing structures and business models adopted by successful incumbents. When American Express entered the charge card business in 1958, for example, it could observe the success of the pricing structure that Diners Club had adopted when it entered in 1950.").

169 See EVANS \& SCHMALENSEE, supra note 1, at 127 (noting declines in transmission and processing costs); Robin Sidel \& Joseph T. Hallinan, MasterCard Swipes Big Debit Account from Visa, WALL ST. J., Jan. 6, 2005, at C3 (noting competition between MasterCard and Visa in debit market and suggesting Discover is preparing to enter market).

170 EvANS \& SCHMALENSEE, supra note 1, at 228 ("Entering the payment card industry as an issuer is fairly easy.").

171 See EVANS \& SCHMALENSEE, supra note 1, at 116 ("The prominence of First Data in both the issuing and acquiring business has led some to suggest that it has the potential to become a competing payment card system."). 
ward the merchant acquirers and issuers. The competitive markets for merchant and individual accounts in turn prevents rent-seeking by those institutions. ${ }^{172}$

\section{The Private Legal Structure}

The rules governing card-based transactions are largely created through a series of private contracts. The constraints both shape and are shaped by the payment systems' technologies. Merchant acquirers negotiate contracts with merchants to obtain the merchants' sales transactions. The degree to which terms vary depends, of course, on the bargaining power of the parties. Small merchants have less leverage than, for example, Wal-Mart. ${ }^{173}$ The existence of alternative networks and the low transactions costs of rerouting transactions, for example, by reprogramming the card readers to route transactions from particular card issuers over particular networks limits merchant acquirers' ability to shift costs onto merchants. Issuers negotiate contracts with consumers, although these negotiations generally center on the interest rate, annual fees, and rewards programs rather than on the remainder of the terms of the contract. ${ }^{174}$ Both issuers and merchant acquirers negotiate contracts with the payment mechanism providers. These contracts are generally boilerplate, but side agreements between the payment mechanism providers and particular financial institutions occur, where the financial institution controls a particularly desirable block of accounts. ${ }^{175}$ Moreover, their members, who are the issuers and acquirers, control the associations.

The associations also impose rules on their member institutions. These rules are created by the associations' boards and membership. Member institutions get votes on the association boards based on their relative size, with larger institutions which provide the association with a greater

172 See EVANS \& SCHMALENSEE, supra note 1, at 171 (noting that "system wars . . have raged since 1958 when American Express introduced its charge card to challenge Diners Club, then the dominant payment card. These wars have provided long-run benefits to consumers and merchants through lower prices, faster service, and enhanced features."); id. at 226-28 (concluding that industry is competitive); id. at 239 ("Prices [received by issuers on balances] declined by almost 35 percent between the first quarter of 1984 and the fourth quarter of 1996 . The price that the typical consumer actually paid, however, decreased by 7 percent over the same period, and would have decreased significantly more had tax laws not been changed.").

173 James J. Daly, Visa's Trillion-Dollar Year, CREDIT CARD MGMT., May 3, 2004, at 38, 2004 WLNR 183657 (Wal-Mart is "widely rumored to have a custom interchange plan with Visa," but the association won't confirm it.).

174 See, e.g., Scott Bilker, Talk Your Way OuT of Credit Card Debt!: Phone Calls to BANKS THAT SAVED MORE THAN $\$ 43,000$ IN INTEREST CHARGES AND FEES (2003).

175 See, e.g., Glenn Cheney, A Credit Card Collision for the Ages, BANK TECHNOLOGY NEws, April 1, 1999, at 8 (describing dispute between VISA and Citibank that led Citi to switch its primary allegiance to MasterCand.) 
number of transactions and dollar volume of transactions receiving more votes. ${ }^{176}$ These rules provide the "law" that governs much of the relationship between financial institutions and both merchants and cardholders. ${ }^{177}$ We discuss the characterization of these contractual terms as law below.

The card based payment systems have bylaws and operating rules that cover a wide range of topics at various levels of detail. The bylaws and operating rules may even be in a variety of different documents. For example, some relatively mundane but practical issues are defined, such as the physical appearance of the cards, including the position of the association logo, font, inclusion of security measures such as holograms and security numbers, and a card design approval process. ${ }^{178}$ The operating rules also specify how cards should be packaged, transported, and stored. ${ }^{179}$ The association bylaws and operation rules also cover standard corporate matters, including the duties and responsibilities of the board of directors and various advisory boards and councils. ${ }^{180}$ Some payment associations are not really payment associations in the classic sense because they are owned and operated by an unaffiliated non-bank company. ${ }^{181}$ These payment entities typically have councils or advisory boards that have the authority to amend the rules. ${ }^{182}$

In any given dispute between a merchant and a cardholder, the dispute is potentially governed by the contracts between the cardholder and the issuer, between the issuer and the payment mechanism provider, between the merchant and the merchant acquirer, and between the merchant acquirer and the payment mechanism provider plus the rules of the payment mecha-

176 See, e.g., Jason Fargo, Behind Citi's Feud with VISA, CREDT CARD MGMT., April 1, 1999, at 28, (describing Citibank's gain in representation by its shift to MasterCard.)

177 See David V. Snyder, Private Lawmaking, 64 OHIO ST. L. J. 371, 405-06 (2003) (analyzing Visa and Mastercard rules as law).

178 See generally VISA GENERAL RuLES, Volume I, supra note 104, §§ 10.1-10.4; MasterCard Bylaws, supra note 112, §§ 5.1-5.8; NYCE Network Operating Rules, § 4.6 (January 1, 2005); Star Network Operating Rules, Version 1.4, app. D (October 2004); Quest Operating Rules, Version 1.3, ch. 2 (May 2001); ACCEL/Exchange Network Operating Rules, app. D (March 2003). See also, MasterCard International, MasterCard Card Design Standards (2003); Visa Check Card: Design and Branding Standards (2004); Visa PrePaid Card: Design and Branding Standards (2004).

179 See, e.g., American Express, Global Network Services, Business and Operational Policies, \& 8.3, Shipments from Manufacturer to Issuer (October 31, 2004).

180 See e.g., MasterCard Bylaws, supra note 112, art. IV; VISA GENERAL RULES, VolumE I, supra note 104, art. V; NYCE Network Operating Rules, § 2.2 (January 1, 2005); Quest Operating Rules, Version 1.3, App. I (May 2001); and, ACCEL/Exchange Network Operating Rules, $\$ 1.3 .2 .2$ (March 2003).

181 There are many examples of such payment systems. Some examples include: American Express which is owned by American Express; NYCE which is owned by Metavente; Star which is owned by First Data; Exchange which is owned by FiServ; Pulse which is owned by Morgan Stanley; and, Discover which is also owned by Morgan Stanley.

182 See supra note 178. Note that the Star ATM/Debit network does not have such an advisory board. 
nism provider. In most cases, however, the critical document for dispute resolution will be the payment mechanism provider's rules governing disputes, since the payment mechanism providers will require the issuers and merchant acquirers to incorporate those rules into their contracts with consumers and merchants.

These rules are the law of the relationship. They go beyond a contract because the payment mechanism provider agreement is not only a contractual agreement to existing rules but an agreement to a process which generates future rules. ${ }^{183}$ These as-yet-unknown rules are binding on the members of the association. To avoid these rules' application requires exit from the association. The introduction of holograms is an example of the imposition of "new law" by the associations. Both VISA and MasterCard began requiring card issuers to alter their cards to include various security measures such as holograms in the 1990 s. $^{184}$ All card issuers had to include this security feature, which was not a trivial expense. ${ }^{185}$

Most critically, the rules require most disputes to be handled within the institutions established by the rules themselves. That is, consumers, merchants, merchant acquirers, and issuers must make use of the institutions created by the web of contracts amongst them and, in this case, largely derivative of the payment mechanism providers' contracts with the issuers and merchant acquirers.

\section{E. The Context}

To briefly summarize, we have shown that card-based payment systems provide a mechanism to convert a diverse set of interactions, many of

183 See Chris Sagers, The Evolving Federal Approach to Private Legislation and the Twilight of Govermment, (unpublished manuscript, on file with author) ("The more one thinks about it, the more difficult it seems to find any robust and meaningful distinction between 'law' and 'standard' except to say that 'standards' are created by private bodies.").

184 See CHUTKOW, supra note 4, at 180-82 (describing card security measures, including microprinting on logo and holograms); see also CHUTKOW, supra note 3, at 188-89 (describing other security features); Homer Brickey, Credit Card Firms Battling Crooks with Technology, THE PATRIOT LEDGER, June 24, 1995 (describing security features).

185 Industry players hold pricing and cost information as highly confidential and competitive information. However, it is possible to estimate the magnitude of this expense. In a recently 10-Q filing, one of the leading providers of holograms, American Bank Note Holographics Inc., indicated that a "significant portion of the Company's business is derived from orders placed by certain credit card companies, including MasterCard and manufacturers of VISA brand credit cards, and variations in the timing of such orders can cause significant fluctuations in the Company's sales. Sales to MasterCand were approximately $37 \%$ and $45 \%$ of sales for the three months ended September 30, 2004 and 2003." Sales for the quarter ending on September 30, 2003 totaled $\$ 4.6$ million. Sales for the quarter ending on September 30, 2004 totaled \$5.8 million. See American Bank Note Holographics Inc., Quarterly Report (Form 10-Q) (Nov. 12, 2004), available at http://biz.yahoo.com/e/041112/abhh.ob 10-q.html (last visited February 24, 2004). 
which are single episode transactions, into a series of repeat relationships. Thus individual purchases by consumers from separate merchants are transformed into a repeat relationship between the consumer and her issuer and between the merchant and its merchant acquirer. The issuers and merchant acquirers themselves interact in repeat relationships (or are a single entity). Moreover, these relationships are subject to simultaneous competitive forces in many distinct markets: the consumer relationship; ${ }^{186}$ the merchant relationship; ${ }^{187}$ the relationships with the financial institutions; ${ }^{188}$ the choice of payment, ${ }^{189}$ and the terms of that choice. The result of the competitive environment is pressure on the payment mechanism providers, the issuers, and the merchant acquirers to improve the quality and reduce the costs of their products. One important set of improvements produced by this competition is aimed at reducing the frequency of fraudulent use.

By virtue of the web of contracts connecting issuers, consumers, merchants, merchant acquirers and payment mechanism providers, the parties to all these contracts are governed by a set of institutions created in the payment mechanism providers' contracts with issuers and merchant acquirers by reference to the payment mechanism providers' rules. These institutions include rule generation institutions (e.g. "legislatures") and dispute resolution institutions (e.g. "courts"). In the next section we discuss the details of these dispute resolution institutions. This section has shown that several key characteristics are the result of the underlying technology and

186 There are many financial institutions that compete for the consumer, her payments, and her borrowing choices. This competition is not limited to financial institutions licensed by VISA or MasterCard, but also includes other card based payment systems such as American Express, Carte Blanche, Diners Club, Discover, JCB, and a host of privately issued payment cards.

187 There is also an intense competition for merchant acceptance. If the merchant does not accept the payment mechanism/mode/choice, no consumer will want that payment vehicle. Likewise, if no consumers have a particular payment mechanism, no merchant will want to accept it.

188 Each association and even many private companies offering payment vehicles that compete for the attention of the financial institution. Some of these associations are jointly owned by financial institutions (i.e., MasterCard, VISA, The Clearing House, etc.) and others are private companies (i.e., NYCE/Metavente, Star/First Data, Pulse/Morgan Stanley, etc.). The Clearing House, a private company jointly owned by many financial institutions, competes with the Federal Reserve to clear checks while simultaneously competing with card based payment mechanisms to extend the reach of checks into new markets. See http://www.theclearinghouse.org/payment_services/000229f.php (last visited May 27, 2005), for new check-based product offerings currently being pitched to financial institutions. Likewise, ATM networks, such as Star and NYCE, compete with VISA and MasterCard over the routing of debit card traffic, while simultaneously competing for the consumer's choice with other payment mechanisms (cash, check, etc.).

189 Competition extends beyond card based payment systems into other payment systems entirely. At the most fundamental level, the consumer may elect to utilize cash. The consumer may also elect to pay with check. The source of funds for that check has exploded over the years to include many nontraditional sources of funds. A check may draw on: equity in and be secured by a consumer's residence; an unsecured personal line of credit that may not even be associated with a card, at all; a brokerage account, including any line of credit established to purchase equities; corporate bonds (i.e., The General Motors' GMAC Demand Notes investment vehicle); and any other source of value. 
the competitive environment amongst the players in the card-based payment system industry.

First, competition restrains the behavior of the various parties. Because there is real or potential competition at each stage of the web of relationships that comprise the card-based payment systems, no individual entity can exert monopoly power to force disadvantageous terms on others. In effect, competition serves as a substitute for the combination of checks and balances and due process limitations imposed by constitutions in political systems to restrict the scope of their law-making power.

Second, much of the web of contracts is opaque to individual entities and participants. An entity which is solely an issuer, for example, may not know anything about the terms of merchant acquirer-merchant contracts; consumers are likely to know little about the terms of issuer-association contracts, and so forth. In one sense, it is as if the federalism provisions of the United States Constitution were unknown to the residents of the states, and known only to the state governments. Despite this opacity, however, those involved in contracts are restrained by competition from colluding to extract rents from the parties to whom the contracts are opaque. Continuing our political analogy, (perhaps past the point of reasonableness), it is as if individual U.S. states had the option of switching from membership in the United States to membership in Canada, Mexico, the E.U., or a new combination of states at will (and without a civil war). Under such circumstances, the parties to the contracts have an interest in promoting "federalism" even if state citizens are unaware of the terms of the federal constitution. Competition thus overcomes opacity.

Third, the transformation by card-based payment systems of diverse transactions into a limited set of transactions, facilitates the standardization of dispute resolution procedures through the imposition of ex ante procedures which prevent the creation of disputes (e.g. deterring fraud), create an objective basis for resolving disputes (e.g. creating physical proof of authorization of a charge through signatures on charge slips), and restrict the domain of potential disputes by defining possible grounds for disputing charges in the contracts. The ability to affect potential disputants' behavior by contract before a dispute arises is a significant advantage for the resulting dispute resolution mechanism over public legal systems' ex post scope for inducing behavior changes.

Fourth, card-based payment systems' transformation of discrete transactions into repeat interactions allows them to harness reputational effects to make the system work. At the most basic level, all participants gain substantial benefits from the use of card-based payment systems. The potential loss of these benefits motivates parties to (in most cases) comply with the association rules. Thus consumers can lose their cards, merchants their accounts, issuers and merchant acquirers their memberships in associations, and associations their members. The threat of being excluded from future mutually beneficial trades thus motivates participants to behave. 


\section{DISPUTE RESOLUTION SYSTEMS}

One of the interesting features of card-based systems is their ability to reduce the universe of possible complaints to a limited, workable, and finite number of dispute types. Cardholders might claim that the charge was not authorized (e.g. "I did not buy a TV set from that merchant"), that the item delivered does not meet the promised quality ("I bought the TV set but it does not work as promised"), or that the item delivered is unsatisfactory for other reasons ("When I got it home, I realized that the TV set is unattractive in my living room and I do not want it."). The card-based payment systems' dispute resolution processes vary their procedures according to the type of dispute. If the question is only whether the charge was authorized, the factual issues are straightforward: was there an authorized use of the card at the merchant in question? The merchant must demonstrate that it has proof that an authorized use took place (e.g. a signed charge slip) and that it complied with the payment mechanism provider's rules in authorizing the charge (e.g. that it sought authorization, verified the signature on the card, etc.). If the merchant cannot prove the use was authorized (and the exact proof will vary depending on whether the transaction was at a bricks and mortar facility, online, or by telephone), the consumer is likely to prevail. If the merchant can prove authorization and rule-compliance, the merchant is likely to prevail. Our other examples of disputes require different approaches to fact gathering. In the following section, we will explore the process itself, various aspects of automation, the legal basis for the system, fees and incentives, and resulting behavior of the players in the payment system.

\section{A. The Process and Supporting Systems}

Most disputes are initiated by the consumer, once the consumer becomes aware of some difficulty with the transaction. Difficulties generally arise in one of two circumstances: the receipt of the cardholder statement ${ }^{190}$ or when the product or service fails to meet the consumer's expectations. On the cardholder statement, a consumer may notice either that there is an unauthorized charge or that the amount of a particular charge is incorrect. Here the consumer is likely to complain directly to the financial institution issuing his card. With a quality issue, at some point after purchase, the product or service becomes defective (at least from the point of view of the

190 We are using the term "statement" in a very general sense. In today's electronic era, it is important to note that a consumer receives a statement from their financial institution through many different mechanisms, including web based notification, mobile phone notification, paper statements, and on screen display at ATMs, among others. Through any of these mechanisms, the consumer may realize that there is a problem that needs resolution. 
consumer). If the consumer fails to secure an acceptable outcome from the offending merchant, the consumer may escalate the process and complain to the financial institution who issued the card. In both circumstances, the consumer will initiate a dispute.

\section{Initiating a Dispute}

The consumer initiates a dispute by contacting either the merchant or the financial institution that issued his or her card. ${ }^{191}$ The consumer initiates the formal process by contacting the financial institution that issued the card. A customer service employee of that financial institution will categorize the complaint with a code to indicate the reason that most closely resembles the substance of the consumer complaint. Based on the code that is selected, different steps in the resolution process and information may be required. Some of these steps or provision of information will be required prior to proceeding on to the next step. For example, if the consumer disputes a charge because the cardholder either does not recognize the transaction or denies that the transaction occurred, the consumer must notify the issuer in writing that she is contesting the charge. ${ }^{192}$ There are usually no formal requirements for the format of the written charge contest; as long as the consumer includes the information necessary to identify the charge in question and makes the basis of the dispute clear, the issuer accepts the written contest. ${ }^{193}$ Not all disputes require a written letter complaint from the consumer, however. ${ }^{194}$

191 Of course, if contacted, the merchant may issue a full refund or partial refund to the consumer, by submitting a credit transaction through to the payment mechanism, in the same way that the consumer was initially charged. The merchant may also exchange defective merchandise for non-defective merchandise. If, upon contact from the consumer, the merchant corrects the problem to the satisfaction of the consumer, the dispute ends. There are no fees assessed by either the card issuer or merchant acquirer to any other party for settled disputes. This part of the process may appear unrealistic to those who believe banks have an inherent advantage over individual consumers or that the size of a particular party renders any bargain with an individual unfair. However, as described below, the dispute resolution fee structures create significant financial incentives for the merchant to resolve the dispute with the consumer directly, before the consumer complains to her financial institution.

192 If the consumer does not initially notify the issuer in writing (e.g. she calls the issuer rather than writing the complaint) for certain types of disputes, the issuer notifies the consumer that she must put the dispute in writing. An increasing variety of "writings" are acceptable, including web fill-in forms, email, and the like.

193 The dispute resolutions by VISA and MasterCard do not address in great detail how the issuer should interact with the consumer for dispute resolution. MasterCard does require a consumer complaint in writing, but, indicates that an unedited email is acceptable. See MASTERCARD CHARGEBACK GUIDE, supra note 111, 1-31. For certain chargeback codes, MasterCard specifies that the consumer complaint must make certain affirmations to be acceptable. One type of affirmation that may be required is that the cardholder engaged in the transaction. Another type of affirmation is that the con- 


\section{Classifying a Dispute}

All payment mechanism providers have their own unique dispute reason codes and resolution requirements for each of these codes. MasterCard uses approximately thirty reason codes to characterize the dispute; ${ }^{195}$ VISA uses approximately forty. ${ }^{196}$ These reason codes are important to all parties involved in any dispute because each code specifies any unique process steps, the required information necessary to resolve the dispute, and, sometimes, the decision criteria for resolution. Failure to follow a particular process step, failure to provide a specific piece of information, or failure to act within prescribed timeframes all may result in permanently losing the dispute on process (as opposed to substantive) grounds.

There are differences between systems. ${ }^{197}$ For example, if a consumer

sumer first attempted to resolve the dispute with merchant. Not all affirmations are required for every dispute. See id. at 3-6.

194 Some card issuers now accept web based complaints on card transactions. Indeed, the web based card transaction complaint may substantially improve the accuracy of the complaint process. Instead of searching for a transaction from a consumer written letter complaint, the consumer searches and self-identifies the specific problematic transaction. Once the consumer identifies the specific transaction, the consumer next self selects the reason for the dispute from a web based drop-down box, effectively classifying the dispute for the issuer. After selecting the reason, a customized web screen with relevant fields may appear next. For example, a series of fields requesting confirmation that the consumer has already attempted to resolve the dispute with the merchant with a blank date field and contact name at the merchant, would only appear if the consumer had a product quality related dispute. That series of fields would not appear if the consumer denied making the charge completely, because such fields are both unnecessary and irrelevant. After all of the relevant information is collected, it is electronically forwarded through the network to the merchant acquirer and onto the merchant, with no initial human interaction, other than the consumer's completion of the dynamic web based forms. See, e.g., American Express, http://www.americanexpress.com (last visited Feb.1 2005) (note: forms are available only to cardholders who are actually disputing a charge). Consider how such dynamic forms (that vary the information requested, depending on the dispute) prevent a consumer plaintiff from taking two positions that are internally inconsistent or contradictory.

195 MASTERCARD CHARGEBACK GUIDE, supra note 111.

196 VISA GENERAL RULES, VOLUME II, supra note 111.

197 Depending on business strategy, some financial institutions who issue cards issue only one brand, MasterCard or VISA. Given the many associations and alternative brands in the market, and the control mechanisms for each, there are many business strategies that financial institutions elect to maximize value from these associations. For example, a financial institution may elect to issue only MasterCard cards. Such strategies are important to industry structure but do not impact the dispute resolution function. As such, they are beyond the scope of this analysis. Those financial institutions need not concern themselves with the differences among payment mechanism providers. Indeed, those institutions who issue more than one brand must expend additional effort to understand some of the subtleties underlying various reason codes. Unfortunately for financial institutions who acquire for merchants, competitive pressures in most countries demand that acquirers handle multiple payment mechanisms from multiple payment mechanism providers.

Typically, merchants demand that their financial institution support all payment choices they elect to accept from consumers. Otherwise, that merchant would have multiple accounts at multiple financial 
contacts her financial institution complaining that a purchased product no longer functions and the transaction was a VISA transaction, ${ }^{198}$ the issuer institution should classify the complaint with Reason Code 56, Defective Merchandise. ${ }^{199}$ This reason code has a time limit of 120 days from the transaction and certain process steps and information items are required, as discussed below. If the consumer brought the same complaint, and the transaction was a MasterCard transaction, the issuer should classify the complaint as Reason Code 4853, Defective/Not as Described. ${ }^{200}$ As with VISA, this MasterCard reason code has a time limit of 120 days, and certain specific process steps and information items are required, as discussed below.

\section{Gathering Information from the Cardholder}

Once notified, the issuer conducts a preliminary investigation of the contest. This preliminary investigation revolves around the process steps and information gathering required by the classification of a consumer dispute (into a particular reason code). In our example, if the product does not function as the cardholder expected, MasterCard requires a written statement from the cardholder. That written statement must: (1) indicate that the cardholder did in fact engage in the transaction; (2) indicate that the cardholder contacted the merchant to resolve the dispute and the merchant declined to resolve the problem; (3) indicate that the cardholder returned or

institutions, and may have multiple sets of point of sale equipment (for each payment system). This scenario imposes substantial additional overhead onto the merchant. For example, the total incoming revenue would need to be reconciled with multiple bank accounts and reconciliation problems become much more difficult to isolate to one particular payment system. For historical and sometime anti-trust reasons, this scenario exists in some countries.

These multi-payment mechanism provider/brand acquirer financial institutions must understand the requirements of all institutions for which they acquire transactions from merchants. Since most merchants elect to accept cards from multiple payment mechanism providers, to successfully defend themselves these merchants must understand the rules for each payment mechanism. Misclassifying a dispute can be costly to the issuer, both in terms of the fees that are passed back and forth, and more importantly, the issuer may lose the dispute because of the coding error.

198 A payment system will only handle dispute transactions associated with that payment system. Therefore, a transaction that is internally routed where the Issuer financial institution is the same as the Acquirer financial institution (on-us) is not eligible for dispute resolution by Visa, MasterCard, or any other payment system. Likewise, transactions routed under a bi-lateral agreement between two financial institutions are also ineligible for dispute resolution by the brand on the face of the card. See e.g., VISA GENERAL RULES, VOLUME II, supra note $111, \$ 1.1$ (defines Visa rules as uniformly governing disputes for cards with the Visa brand, but indicates that the rules only apply to transactions made using the brand).

199 Id. $\$ 1-224$, Reason Code 56.

200 MASTERCARD ChaRgeback GuIDE, supra note $111, \S 3-113,3.19$, Message Reason Code 4853. 
attempted to return the goods; (4) provide a description of the goods or services disputed; (5) explain how the goods did not conform, specifically stating if the goods were of a different quality, quantity, color, or size than expected, or (6) whether the goods were damaged during the shipping process; and, (7) provide any additional documentation that may be necessary to resolve the dispute. ${ }^{201}$ VISA's requirements for its equivalent chargeback reason code are substantially similar. ${ }^{202}$

Since all customer service employees of a financial institution are not likely to know or understand the requirements of every rule, the issuer may have employed technology in their customer service system to explicitly script these steps and information requirements for the customer service agent. ${ }^{203}$ After the customer service agent classifies this dispute as a Defective Merchandise dispute, a series of questions will appear on the agent's screen for the customer service agent to ask the consumer. These questions will mirror the requirements of that particular reason code. ${ }^{204}$

In this example, after the dispute is classified the issuer is likely to ask the cardholder whether they have contacted the merchant. If the cardholder has not yet contacted the merchant and the dispute is submitted for formal resolution, the issuer and cardholder will lose this dispute. ${ }^{205}$ Therefore, the issuer will advise the cardholder to contact the merchant first to resolve the problem and, if and only if the merchant is not willing to resolve the problem, then open a formal chargeback to resolve this problem.

Assuming all of the requirements for this reason code are met using the technology and expertise of the issuer's financial institution, the item will be formally charged back to the merchant; we describe the chargeback process below.

201 Id. $\$ 3.19$.

202 VISA GENERAL RULES, VOLUME II, supra note 111 , 1.

203 Interview with William Green, Manager, Chargebacks and Retrievals Processing, Electronic Data Systems, in Westlake, Ohio (Feb. 6, 2004) [hereinafter, Interview, Green] (describing how EDS implemented various work queues and scripts to simultaneously comply with both Visa and MasterCard's rules, to maximize the likelihood that EDS' institutional customers would win the disputes, or at least, minimize the number of lost disputes); see also Interview with Robert Sadeckas, Executive, Business Process Management, Electronic Data Systems, in Westlake, Ohio (Feb. 6, 2004) [hereinafter, Interview, Sadeckas] and Interview with Loretta Hui, Assistant Vice President, Claims and Adjustments, Citishare Corporation, New York, N.Y. (Feb. 15, 2005) [hereinafter, Interview, Hui].

204 See Interview, Green, supra note 203; see also Interview Sadeckas, supra note 203, see also Interview, Hui, supra note 203.

205 See, e.g., VISA GENERAL RULES, VOlume II, supra note 111, at 417; MASTERCARD Chargeback GuIDE, supra, note $111, \$ 3.19 .1$, Message Reason Code 4853. See also, Interview, Green, supra note 203; Interview, Sadeckas, supra note 203; Interview, Hui, supra note 203. 


\section{Gathering Information from the Merchant: The Retrieval Request}

Certain disputes require a retrieval request. A retrieval request is the process the issuer may utilize to retrieve a copy of the transaction receipt from a merchant or merchant acquirer. ${ }^{206}$ When the issuer initiates a retrieval request, the request is passed onto the association, which in turn passes it onto the acquiring financial institution, which then either responds on behalf of the merchant, or passes the request onto the merchant.

Since the receipt ${ }^{207}$ ultimately documents the payment obligation, the issuer may initiate a retrieval request sua sponte for its own investigations of fraud, rules violations, or as a result of a cardholder request or dispute. To prevent abuse, the payment mechanism providers have imposed some limits to retrieval requests. For example, VISA has prohibited requests for original transaction receipts. ${ }^{208}$

Another limit on retrieval requests is the requirement that the issuer provide certain minimum information elements to secure a retrieval request. Some of these elements include a reference number, account number, transaction date, category code, transaction amount, and merchant location. ${ }^{209}$ By requiring that the issuer supply this information for a retrieval request, the payment mechanism provider curtails the sort of open-ended requests that are common in the discovery portion of public dispute resolution. For example, the structure of retrieval system makes it challenging for an issuer to request copies of all charge authorizations during a particular period. The issuer would need a great deal of information to make such a request, some of which, it simply does not possess. This limitation on the "discovery" permitted or enabled is an important factor in holding down the costs of the process.

Chargeback rules may require retrieval requests for some disputes because of the nature of the dispute itself. For example, if an incoming transaction does not have enough information to process the transaction, an issuer may only chargeback this item after attempting to reconstruct the missing item, through a retrieval request. ${ }^{210}$

206 See MasterCard Dictionary, supra note 40, at 91.

207 We are using "receipt" very generally here. Historically speaking, merchants used to send their card based payment system receipts into their financial institution for payment, as with pre-Check 21 drafts. Now, the receipt is primarily electronic and both the merchant and cardholder receive copies for their own record keeping. Notwithstanding the improvements in back-office processing that eliminated the need for merchant submission of most paper receipts, the rules still impose requirements on the creation of a receipt. See, e.g., VISA GeNERAL RULES, VOLUME I, supra note 104, §4.2.J, (requiring that a POS terminal must generate an Electronic Transaction Receipt).

208 See, e.g., VISA GENERAL RULES, VOLUME II, supra note 111, §1.2.B.2, Requests for Transaction Receipt Originals.

209 See, e.g., VISA, GeNeral RULES, VOlUME II, supra note 111, \$1.2.D, Dispute Resolution Rules, Retrieval Requests. See also, MASTERCARD Chargeback GuIDE, supra note 111 , at D-1.

210 See MASTERCARD CHARGEBACK GUIDE, supra note 111, Chargeback Code 4802. 
Other than the processing costs (see below), a retrieval request by itself does not have a monetary impact on any of the parties involved with the payment. At this point, the consumer's account is not credited for the amount of the transaction and the merchant's account is not debited for the transaction amount.

In our example of a consumer complaining about defective merchandise, no retrieval request is required by rules because the consumer is not denying the transaction itself. Indeed, the chargeback rules about defective merchandise require the consumer to affirmatively state that the cardholder participated in the transaction. That affirmative statement eliminates reason codes related to transactions that the consumer denies making altogether. ${ }^{211}$

For retrieval requests, an acquirer may charge an issuer a fee based on the timeliness of the acquirer's response. Rapid responses from the acquirer are rewarded with larger fees. For example, an acquirer may charge an issuer $\$ 8$ for certain responses within five days of the issuer request and $\$ 0$ for responses that take more than 21 days. ${ }^{212}$ VISA's rule is even more punitive to acquirers because if an acquirer does not meet the retrieval and fulfillment standards, VISA will assess an increased transaction fee for all future fulfillments. ${ }^{213}$ Fees also vary depending upon the reason for the request. If the retrieval request was required because the merchant information was incorrect (i.e., the name of the merchant was different than the actual name, the location was incorrect, etc.), the issuer may collect a nominal punitive fee from the acquirer for misinformation. ${ }^{214}$

\section{Charging a Transaction Back to the Merchant}

Unlike a retrieval request, a chargeback transaction has a monetary impact on the consumer, issuer, association or other payment mechanism provider, acquirer, and merchant. Upon initiating a chargeback to the merchant acquirer, the issuer temporarily removes the charge from the consumer's account, stopping the accrual of interest and fees associated with

\footnotetext{
211 Consider how such affirmations prevent multiple contradictory positions that are permitted in public dispute resolution forums.

212 MasterCard Chargeback GuIDE, supra note 111 , MasterCom fees, Retrieval Requests and Fulfillments, 6-21.

213 See VISA GENERAL RULES, VOLUME II, supra note $111, \$ 1.2 .1$, at 1-15.

214 See MASTERCARD Chargeback Guide, supra note 111, Part I, \$F, Message Code 7612 Retrieval Handling Fee; For Issuer Use to Penalize an Acquirer for Incorrect Information Verified by the Retrieval Request Document; VISA GENERAL, RULES, VOLUME II, supra note 111, \$1.2.1.2.a at 1-15 ("The Issuer may collect a [nominal] handling fee from the Acquirer . . . for a Retrieval Request resulting from a significantly different Merchant name or incorrect city, state, foreign country, or Transaction Date in the Clearing Record.").
} 
the charge. ${ }^{215}$ Likewise, upon receipt of a chargeback, the acquirer financial institution will debit the merchant's account, reduce incoming settlements by the amount or hold the amount in a reserve account. The monetary impact of the chargeback gives the merchant a strong incentive to resolve the dispute quickly. Moreover, the ability of the issuer and merchant acquirer to control the fund eliminates the need to worry about enforcing the decision. ${ }^{216}$ In addition, the issuer may collect a nominal handling fee from the acquirer for each chargeback processed. This handling fee is in addition to the amount of the transaction itself. The handling fee is designed to cover the information gathering and complaint codification process. It also shifts some of the handling costs to the merchant acquirer.

\section{Representment}

Based on its investigation, the merchant acquirer and merchant determine whether or not to accept the chargeback. If it accepts the chargeback, the merchant acquirer removes the amount in question from the merchant's account permanently. If the merchant acquirer rejects the chargeback, it represents the charge to the issuer.

When the merchant submits a representment of a transaction, the merchant must have a reason and the associated documentation required for that reason code, to represent the transaction. The payment mechanism providers have codified these reason codes. Fundamentally, the representment reason codes are grounded in the rules for any given chargeback. If the issuer did not follow the chargeback rules or if the chargeback was substantively improper, the acquirer or the merchant may represent the item to the issuer. In our example of a consumer complaint about defective merchandise, the merchant may represent if the initial chargeback was unsubstantiated. In this case, an unsubstantiated chargeback would not include the required written consumer letter or, if a letter was included, not contain all of the required elements. The acquirer may collect a more significant handling fee from the issuer for each representment processed. This fee is designed to cover the research costs of the merchant acquirer and to shift some of the response cost to the issuer. In this way, the issuer has an incentive to make the complaint as accurate as possible when initially submitted.

215 The issuer may still reduce the cardholder's credit line for the amount, because until the temporary credit is permanent, the charge may be reinstated.

216 See Perritt, supra note 42, at 676 ("Many forms of ADR involve a readily available fund (usually the payment for the disputed transaction) as a way of satisfying a decision for either disputant. The availability of the fund often is underestimated as a consideration. This consideration may explain why intermediary-provided dispute resolution, such as credit card chargebacks and escrow arrangements, prove more attractive in practice than independent third-party mechanisms such as arbitration or mediation. The successful party to an arbitration must still be concerned about the enforceability of an arbitration award against a reluctant loser."). 


\section{Acceptance or Rejection of Representment and Further Charge- back Rights}

The issuer then decides whether or not to accept the representment. If it accepts the representment, the issuer releases the funds back to the acquirer bank. If rejected, this stage of the process ends. The issuer may then repost the amount in question to the consumer's account or decide to pay the charge itself, depending on the facts of the case and the value of the consumer's relationship with the issuer. The issuer may also collect a handling fee in addition to any fees previously assessed to the issuer by the acquirer if the issuer elects to chargeback and escalate to arbitration, as discussed below. In this way, the acquirer has an incentive not to represent items that are likely to be escalated to arbitration.

\section{Association Arbitration and Mediation}

If the issuer does not accept the representment, the issuer may appeal to the association. This is the first point in the process involving a neutral decision maker. Analysis of the substance of the dispute begins and ends with the underlying merchant-consumer transaction. When a consumer purchases goods or services from a merchant, using a card, that transaction is governed by any explicit or implicit contract between the consumer and merchant, including the implicit or explicit warranty and the warranty's limitations.

If a dispute is appealed, the association investigates and makes a determination. The investigation is typically limited to the materials provided by each member to the other member during the earlier stages of the dispute resolution process. Indeed, MasterCard's rules explicitly state that it will discard any materials submitted outside of the normal retrieval, chargeback, representment, and arbitration processes. ${ }^{217}$

In the arbitration process, the associations are not limited to awarding the amount in contest; the association may fine either or both parties for any errors it uncovers in the course of the investigation and may investigate rule violations related to the transaction regardless of their connection with the merits of the dispute. ${ }^{218}$

The party which loses the appeal to the association can then appeal once more within the association based on claimed errors in interpreting the rules. The loser can also make an equity-based claim (i.e., "It isn't fair that

217 See MASTERCARd ChargebaCK GUIDE, supra note $111, \$ 4.4$, at 4-5.

218 In any circumstance where a member financial institution believes that another member financial institution is out of compliance regarding a particular transaction or set of transactions, that member institution may bring a compliance case against the other member even without a dispute. 
I lost") against the other financial institution outside the formal process. The winner has complete discretion over whether to grant such a claim. ${ }^{219}$

In the association arbitration processes, the appeals follow the English rule, with the loser paying the costs of the appeal process. The associations typically charge a significant filing fee ${ }^{220}$ and an even more significant administrative fee to the member found responsible for the case. ${ }^{221}$ In addition, the association may assess fees for technical violations during the dispute resolution process regardless of whether the member won or lost the dispute. Such technical fee violations include persisting with an invalid chargeback; submitting an invalid representment; submitting invalid documentation; and processing a chargeback beyond the permitted time limits. ${ }^{222}$

\section{B. Incentives}

An issuer bears the primary costs of consumer behavior, at least for those consumers that are that financial institution's customers. Therefore, the issuer will question the consumer early in the process to ensure that the dispute is legitimate and that the required documentation is available prior to submitting a dispute. If the dispute appears legitimate, and the consumer is a profitable consumer, to avoid the fees the issuer may simply remove the charge from the consumer's statement, without actually charging back the amount in question.

With the narrow exception of civil rights laws, ${ }^{223}$ there is no legal requirement that an issuer serve all people without regard to cost or profitability of that consumer. Therefore, an issuer has several options with consumers who are costly to service. The issuer may impose higher fees, including higher annual fees, late fees, and higher interest rates to expensive consumers. The issuer may elect not to renew a consumer account or the issuer may terminate an existing account. ${ }^{224}$ Given the financial incentives de-

219 Statistics for such scenarios are not available. However, evidence exists that winners occasionally grant internal reviews of such disputes. See Interview, Hui, supra note 203 . The mere fact that such a review possibility exists and is sometimes granted without any force whatsoever, is evidence of a process where the potential for and the value of repeat interactions is quite significant. In Hui's view, "it is important to be standing on principle in any decision, and to be sure that the other [financial institution] believes it, even if the result is unfavorable to that party." Id.

220 See MASTERCARd Chargeback GuIDE, supra note 111, §4.5, Fees and Assessments, at 4-6.

221 Id.

222 See, e.g., VISA GENERAL RULES, VoluME II, supra note 111, 2, at 3.G.4.c ("Visa, USA assesses the following fees to the responsible Member ... . [significant] penalty fee for each technical violation of the VISA U.S.A. Inc. Operating Regulations.").

223 The Equal Credit Opportunity Act and Regulation B are two examples of such laws. See generally, Equal Credit Opportunity Act, 15 U.S.C.A $\$ 1691$ (2005); see generally, 12 C.F.R. $\$ 202.1$ 202.17 (2005).

224 Although cardholder initiated disputes are currently not reported to the credit bureaus, the fact that an account was closed by the issuer is reported and recorded by the credit bureaus. Other unrelated 
scribed above, as a consumer submits disputes for resolution, that consumer becomes less profitable.

Likewise, merchant acquirers bear the costs associated with merchants with chargebacks. If an acquirer receives a chargeback, and the merchant is a highly profitable merchant, the acquirer may simply accept the chargeback and not deduct the amount from the merchant's account. The acquirer may take this action as an act of goodwill.

Merchants with more disputes are more expensive to service and high dispute rates also indicate that there may be other problems with that merchant. An acquirer financial institution may elect to substantially increase the discount rate for its merchant customers who receive too many disputes. Merchants with particularly high rates of chargebacks may be eliminated from the payment system altogether. Merchants who commit fraud ${ }^{225}$ can be permanently banished by the acquirer financial institution with either or both VISA and MasterCard through the maintenance of a terminated merchant file. Both associations require all merchant acquirers to check the terminated merchant file prior to opening a merchant account. ${ }^{226}$ This file acts as a substantial deterrent for those merchants and their owners who elect to deliberately defraud the payment system.

\section{COMPETITION, REgulation, \& THE EVOLUTION OF THE SySTEMS}

As we discussed above, we contend that two of the crucial elements that make the card-based payment systems' dispute resolution systems successful are their ability to transform single-instance transactions (e.g. potential disputes) into repeat-play transactions, through the insertion of the association, issuer and merchant acquirer into the consumer-merchant trans-

lenders are likely to ask a borrower why the issuer closed their account. This information sharing creates further incentives to prevent abuse of the chargeback system.

225 There are numerous merchant frauds that are likely to result in global permanent banishment from a particular payment system. One such fraud is the acceptance and submission of transactions from known stolen cards, and splitting of the proceeds with the criminals who pilfered the card. This fraud works (in the short term) because not all stolen cards are known at the time of the card theft and not all consumers complain about small transactions. Therefore, merchants who are caught colluding with criminals to submit false transactions to collect the proceeds, may be permanently banished from accepting cards. Another such fraud is the deliberate acceptance of cards and non-shipment of goods. Merchants who commit this kind of fraud withdraw the incoming deposits and disappear. Eventually, cardholders may charge these purchases back to the merchant, but, there will be no merchant left to accept the chargebacks. Therefore, the merchant acquirer is responsible for this fraud and will likely permanently banish the owners of that merchant from future participation in the payment system. Often, these frauds initially appear in the chargebacks process.

226 MasterCard Bylaws, supra note $112, \S 9.5 .2 .4$ at 9-6 (requiring acquirers to report merchants to association); VISA GENERAL RULES, VOLUME I, supra note 104, \$4, at 2.D.1.b (“An Acquirer must: query the terminated merchant file to determine if the prospective Merchant has been terminated for cause ...."). 
action, thereby harnessing reputational incentives and imposing ex ante constraints on potential disputants' behavior through requiring structured behavior by participants to the transactions. Neither feature was an intentionally designed characteristic of the payment systems. Both characteristics evolved in response to market pressures during the multiple attempts at constructing card businesses by banks and other financial institutions in the 1950s.

In addition to the market pressures, card-based payment systems have been affected by regulatory pressures. While we believe, as we argue below, that these regulatory pressures have not been determinative of the success of the card-based payment systems' dispute resolution systems, we briefly describe the major regulatory events and analyze their influence as well.

\section{A. The Creation of Card-Based Payment Systems}

Hotels, oil companies and department stores all began to issue cards to their customers before World War I, but these systems were limited to specific merchants rather than general purpose systems. ${ }^{227}$ The first major step in the creation of the modern card-based payment systems was the beginning of networks in 1948 when a group of New York City department stores banded together to make their cards interchangeable across merchants. ${ }^{228}$ Card-based payment systems did not become widespread until the development of the Diners Club (1950) and American Express (1958) charge cards in the $1950 \mathrm{~s}^{229}$ Other companies also attempted to create general purpose cards during the 1950 s but all but these two failed. ${ }^{230}$ Diners Club initially targeted wealthy residents of Manhattan for use at restaurants. ${ }^{231}$ The companies' value proposition to prospective customers was

227 EVANS \& SCHMALENSEE, supra note 1, at 61.

228 EVANS \& SCHMALENSEE, supra note 1, at 62.

229 See GrossmAN, supra note 65, at 262-263 (describing start of Diners Club); id. at 280-285 (describing start of American Express card). Although American Express did not produce a card until 1958, the company considered the idea as early as July 1946 but rejected it because of fear it would compete with the travelers' check market. Id. at 264-266. Later the company rejected moving into the market because it saw Diners Club and other early card companies as "shlock" operations. Id. at 265266. When it finally decided to enter the market, American Express initially considered buying Diners Club. Id. at 274.

230 EVANS \& SCHMALENSEE, supra note 1 , at 63.

231 See GROSSMAN, supra note 65, at 262 (Diners Club initially intended as "a universal restaurant card that would be accepted at all major New York restaurants."); EVANS \& SCHMALENSEE, supra note 1 , at 84 (describing early industry as targeting "selected Manhattan gourmets"); id. at 85 ("Credit cards have led the way in taking a product that was originally targeted to well-off restaurant goers in Manhattan and making it available to the masses."). 
that the cards freed the customer from carrying cash, ${ }^{232}$ provided thirty day payment terms, ${ }^{233}$ and gave the prestige of membership in an elite group of card-holders. ${ }^{234}$ For merchants (Diners Club targeted primarily restaurants at first but soon expanded to "florists, gourmet shops, motel chains," and Hertz rental cars), ${ }^{235}$ the companies would automatically deposit the charged funds in the merchants' accounts, freeing them from handling incoming cash, and also handle collections from card-holders. ${ }^{236}$ In particular, Diners Club and American Express assumed the risk that cardholders would not pay their monthly bills. If a cardholder did not pay, the restaurant retained the payment from the card issuer.

By 1957, Diners Club had almost 500,000 cardholders and charge volume of $\$ 7$ million per month. ${ }^{237}$ When American Express entered the market in 1957, it purchased the American Hotel Association and Gourmet magazine's charge cards, giving it 190,000 cardholders before it even began operations. $^{238}$ Applications brought in another 60,000 cardholders by the first day. ${ }^{239}$ The company had more than 17,500 establishments committed to accept the card by the first day as well, helped by the company's prestige. ${ }^{240}$ The card grew quickly, reaching 900,000 cardholders and 82,000 merchants in $1962 .^{241}$ Both cards were sufficiently valued by consumers that the companies were able to charge an annual membership fee. ${ }^{242}$ They were also valued by businesses, allowing the card companies to charge a "discount fee" of a percentage of the transaction. ${ }^{243}$ Diners Club initially

232 See EVANS \& SCHMALENSEE, supra note 1, at 94 ("By reducing the need for cash balances, payment cards provide a potentially enormous benefit to consumers."); GROSSMAN, supra note 65, at 262 (Diners Club was founded when Frank McNamara "had just finished a meal at a restaurant when he realized to his dismay that he could not pay the check."); EVANS \& SCHMALENSEE, supra note 1, at 212 ("Simply put, payment cards are much easier to carry around and use than are most of the other payment methods.").

233 See GrosSMAN, supra note 65, at 262 ("In the card, club members had blank-check, interestfree charge privileges and a notable convenience.").

234 Id. at 262.

235 Id. at 263.

236 Id. at 262.

237 Id. at 274.

238 Id. at 283.

239 GrossmaN, supra note 65 , at 284.

240 Id. at 285.

241 FRIEDMAN \& MEEHAN, supra note 95, at 59.

242 GROSSMAN, supra note 65 , at 263.

243 "Transaction" is a term of art in the payment system industry. It refers to the individual exchange that occurs when a consumer utilizes a payment mechanism to transfer value to a merchant (e.g. when a consumer swipes their credit or debit card through a merchant's terminal). We use the term in this paper as it is used in the industry rather than to mean a deal (e.g. acquisition of one company by another), as lawyers and investment bankers often do. See also, MASTERCARD DICTIONARY 104-106 (for thirteen different definitions of various types of transactions or items related to the core concept of a transaction). 
charged a 7 percent merchant discount; more recently typical merchant discount rates ranged from 1.6 percent for Discover to 2.75 percent for American Express. ${ }^{244}$ (Diners Club is now co-branded MasterCard, ${ }^{245}$ and therefore, the discount rate has fallen to the MasterCard levels.)

In effect, the early payment cards were simply the extension of the type of credit provision made possible in industries selling physical inventory by factoring to the consumer-restaurant transaction. As we described earlier, in a factoring transaction a financial intermediary provides a business with credit secured by the business's inventory, while that inventory is being sold to customers. ${ }^{246}$ Factoring required, however, a relatively constant level of inventory of durable assets to secure the credit and costly physical monitoring ${ }^{247}$ to ensure the merchant kept the required level of inventory. Providing credit on this model to a restaurant would not, of course, be possible because the restaurant's "inventory" is the accounts receivable from individual diner's consumption of food. Without physical, durable assets, restaurants lacked the collateral to obtain loans based on value.

Diners Club changed that. When Diners Club handled a consumer purchase of a meal in a restaurant, Diners Club paid the restaurant the bill for the charged meal (less the discount) before Diners Club received its payment from the consumer. When Diners Club issued the card to the consumer, it selected only people it thought most likely to be able to ultimately pay the bill, although its initial credit screening was quite crude. ${ }^{248}$ Diners Club then essentially offered the restaurant financing for those portions of the receivables charged to the card, monetizing the cardholders' promises to pay in the future for the meal they had already eaten. Thus not only were consumers able to buy meals on credit, but the restaurant was able to finance its receivables.

As this brief account makes clear, the credit card business was not created to harness reputation or to structure transactions to reduce the frequency of disputes. It was created, like most businesses, in the hopes of making money by offering a service. Nonetheless, the nature of the busi-

244 See EVANS \& SCHMALENSEE, supra note 1, at 129.

245 Diners Club and MasterCand announced a relationship where Diners Club cards would become co-branded MasterCard. See http://www.dinersclubnewsroom.com/view_release.cfm?id=183 (April 29, 2005) and http://www.dinersclubnewsroom.com/view_release.cfm?id=199 (September 20, 2005). In effect, the Diners Club card is effectively a MasterCard. When the card is presented to a merchant, that card is treated as a MasterCard, with the discount rates applicable to MasterCards.

246 See note 73 supra.

247 There are also problems associated with merchants who secure more than one loan on the same inventory, particularly because of historic information gaps associated with collateral. These information gaps disappear with financing based on a specific consumer transaction.

248 GROSSMAN, supra note 65 , at 263 (noting that initial list of prospects was simply a mailing list of 5,000 sales managers). 
ness produced problems that led the industry to develop measures which introduced reputation and structure.

The new charge cards quickly developed problems. Abuse and fraud were major risks, large enough that many early observers did not believe Diners Club could survive. ${ }^{249}$ Because of the lack of real-time connections between the merchants and Diners Club and American Express, there was no way to immediately stop a card's use if a cardholder began to abuse it. ${ }^{250}$ American Express lost $\$ 4$ million on the charge card operation in its first two years of operation, largely because of a lack of credit screening of prospective cardholders. ${ }^{251}$ Indeed, by 1960 losses had reached $\$ 10$ million and senior executives were not convinced that the card would survive. ${ }^{252}$

At the same time as Diners Club and American Express were creating their closed networks, banks were also attempting to enter the credit card market. In 1951 Franklin Bank in New York expanded the market by creating an applicant screening process that allowed it to issue revolving cards outside the narrow demographic relied on by American Express and Diners Club. ${ }^{253}$ Franklin began by simply sending cards to prospective cardholders without credit screening. ${ }^{254}$ Eventually, Franklin developed a profile of

249 Id.

250 Id. ("[M]any people doubted that the company would survive [due to credit risk] . . A large number of card abuses would bankrupt the Diners' Club.")

251 Id. at 286 ('The company had done a poor job in evaluating credit risks, which was understandable since it had no experience with handing out blank-check credit, or any credit for that matter.") Screening card holders remained an issue for issuers into the 1970s. As Chutkow's history of VISA notes, "many banks issued cards indiscriminately, and not only to their own customers. Some banks bought mailing lists and issued cards to everyone on them, without any credit analysis or screening. Mass mailings led to massive thefts, often directly from mailboxes, and that led to massive fraud." CHutKow, supra note 4, at 154.

252 GROSSMAN, supra note 65, at 299. Starting a new card operation remains expensive. Dean Witter "incurred substantial initial losses as it spent money prospecting for customers and building merchant acceptance" but ultimately became profitable. EVANS \& SCHMALENSEE, supra note 1, at 281. To cope with the losses, American Express raised its fees from $\$ 6$ to $\$ 10$ a year and increased the merchant discount rate. The losses stopped, and by 1967 card volume reached $\$ 1.1$ billion, the number of cardholders reached 2 million, and the card earned American Express $\$ 6.5$ million in profits. GROSSMAN, supra note 65 , at 303 . This problem continued to plague card issuers, with Citibank losing more than $\$ 500$ million over three years after it introduced a national marketing campaign for its credit cards and American Express experiencing twice the industry average uncollectible debts with its Optima card. See FRIEDMAN \& MEEHAN, supra note 95, at 65; see Rob Wells, American Express Chief Brings Stability to Card Giant, SEATTLE TIMES, Oct. 3, 1993, at D7 [1993 WLNR 1149106].

253 CHUTKOW, supra note 4, at 59-60.

254 AURIEMMA, supra note 5, at 4. Banks issuing early credit cards had several problems. First, in many cases they issued cards without prescreening the cardholders for creditworthiness. AURIEMMA, supra note 5, at 9 ("The most aggressive banks sent cards to deposit customers, loan customers, safe deposit customers, and any other customers whose addresses they could obtain. Many banks bought mailing lists consisting of names from magazine subscriptions, driver's license registrations, and the like. Not surprisingly, some of the individuals who were issued cards did not manage the credit well."). Second, even when they did screen, banks sometimes used inappropriate criteria. Id. ("Some banks 
customers it believed likely to pay and vastly expanded the number of people with access to a card-based payment system. ${ }^{255}$ Franklin's card, however, was useful only in the New York metropolitan area. ${ }^{256}$

Banks across the country began to issue proprietary cards. ${ }^{257}$ By 1953 there were nearly 100 banks issuing proprietary credit cards in Manhattan alone. ${ }^{258}$ While the markets for these cards were geographically limited (e.g. a New York bank's card was accepted only by merchants in the New York area, and a San Francisco bank's card was accepted only in the San Francisco area) there was intense competition among banks within each geographic region. ${ }^{259}$

The proliferation of cards led to complications on the merchant side, however, since each bank had to individually create a relationship with each merchant to allow the merchant to accept its card. Merchants were reluctant to accept additional cards unless there was a substantial base of consumers with that bank's proprietary card. ${ }^{260}$ To get the necessary cardholder base, banks offered successively more generous terms and features to cardholders.

The transactions costs of the proliferation of cards for merchants were substantial, since each proprietary card required a separate contract, bank account, and processing with the issuing bank. Within a few years many of the banks exited the market because they lacked sufficient cardholder and/or merchant bases to profitably operate proprietary card systems. ${ }^{261}$ By 1960 , the boom was over but a competitive market in proprietary cards with

were inexperienced with extending unsecured credit-especially revolving credit associated with a credit card. The credit approval criteria that had served banks well when making installment loans, such as automobile or home loans, proved to be inadequate for extending credit through cards.") Similar problems arose when banks began converting ATM cards into debit cards. See BALTO, supra note 63, at 1102 ("A large part of the [fraud] problem arises when offline debit cards are issued in an unsolicited manner. Banks often reissue their online ATM cards as a VISA check card which can be used as either an ATM or an offline debit card.").

255 CHUTKOW, supra note 4, at 60 (describing credit screening).

256 Steve Rhode, The History of Credit and Debt, http://www.myvesta.org/history/history _creditcard.htm (last visited May 31, 2005).

257 EVANS \& SCHMALENSEE, supra note 1, at 63.

258 CHUTKOW, supra note 4, at 60 ("By 1955, about 100 banks were operating card programs. . Most of these bank cards were usable only in a small local area, and few generated enough transaction volume to be profitable."); AURIEMMA, supra note 5, at 4 ("Franklin National Bank's credit card program was copied by hundreds of other banks in the late 1950s and early 1960s.").

259 See EVANS \& SCHMALENSEE, supra note 1, at 63-64 (describing competitive environment that saw banks losing large amounts of money competing in the new business).

260 See Evans \& Schmalensee, supra note 86, at 887 ("payment cards were useful to consumers only if they were accepted by many merchants, and they were useful to merchants only if they were carried and used by many consumers").

261 EVANS \& SCHMALENSEE, supra note 1, at 63-64 ("By 1962, many bank payment card plans had fled the field, including Chase Manhattan's."). 
local merchant bases existed throughout the country in most major metropolitan areas. ${ }^{262}$

The proprietary era thus had two critical weaknesses. First, the transactions costs of merchant-bank relationships were high because of the need for individual contracts with each issuer. The individual nature of the merchant-bank relationships also reduced the scope for banks to impose structure on the credit card transactions, as merchants would not be willing to follow different procedures for each card they accepted. Second, the issuerconsumer relationship lacked sufficient reputational guarantees. Banks had selected cardholders based on little more than the magazines the cardholders subscribed to; unsurprisingly, the cardholders had "defected" from the deal by not paying their bills in a timely way.

\section{B. The Rise of Associations}

In the mid-1960s two crucial innovations developed that took opposite approaches to solving the problems created by the regional-based proprietary cards. In California, Bank of America had the most extensive set of relationships with merchants, allowing its cardholders to use their Bank of America credit card at the widest range of merchants in California. ${ }^{263}$ Realizing that this set of relationships with merchants had value to other banks as well, and that it had one of the few profitable bank card operations, in 1966 Bank of America decided to license access to its merchant portfolio to banks from other states, creating "BankAmericard." 264 Within two years, forty-one banks were issuing BankAmericards and another 1,823 banks were signing up merchants or issuing cards as licensees of the forty-one. ${ }^{265}$ Bank of America limited the fraud problem by giving each card a credit limit ( $\$ 300$ for "simple" cards and $\$ 500$ for preferred customers) and requiring merchants to call in for authorization for transactions over that amount. ${ }^{266}$

Banks who licensed the merchant portfolio from Bank of America physically added the BankAmericard logo to their credit cards, in addition to maintaining their own name on the card. ${ }^{267}$ Thus, for example, a consumer in Nevada would have a First National Bank of Reno card which was also a BankAmericard. The franchise model had serious problems, with franchisees losing hundreds of millions of dollars in the first years. ${ }^{268}$ Later

EVANS \& SCHMALENSEE, supra note 1 , at 64.

EVANS \& SCHMALENSEE, supra note 1 , at 64.

CHUTKOw, supra note 4, at 69-70 (describing how Bank of America decided to license the use

Id. at 70 .

Id. at 64 .

EVANS \& SCHMALENSEE, supra note 1, at 65.

CHUTKOW, supra note 4, at 92. 
Bank of America spun off the card network as National BankAmericard

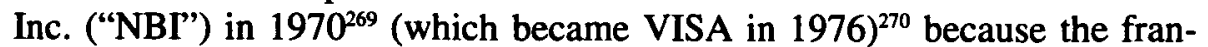
chise model was unworkable. ${ }^{271}$ The following year, the newly independent network had $\$ 3.7$ billion in charges, up from $\$ 2.7$ billion the year before. ${ }^{272}$

Bank of America charged the licensing banks a variety of fees. Not only did it charge licensees for the use of its trademark, it introduced a concept it called "Interchange" which was a fee for each transaction at a Bank of America merchant. ${ }^{273}$ The development of the interchange was critical to making the open network function. ${ }^{274}$ Merchant acquirers cannot predict in advance which issuer's cards will be used at their merchants, requiring them to either negotiate ex ante a price for the obligation generated by the underlying transaction with every issuer in the network or to negotiate $e x$ post once the issuer was identified. Of course, in an ex post negotiation the merchant acquirer would be in a difficult bargaining position since the only buyer available would be the cardholder's issuer. ${ }^{275}$ Alternatively, the merchant or merchant's bank could negotiate bilateral agreements with every other bank in the system. If, for the sake of argument, there are 15,000 participating financial institutions, and the merchant desired $100 \%$ coverage, that would translate to numerous individually negotiated contracts. ${ }^{276}$ By setting a system-wide pricing and negotiating structure for the obligations, the networks solve this coordination problem inexpensively, both in terms of the upfront setup and the ongoing maintenance.

At about the same time, banks in other areas began to form associations that truly shared the merchant portfolios. ${ }^{277}$ For example in 1965 , the Midwest Bank Card Association was formed by four Chicago banks, ${ }^{278}$ in 1966 Interbank was formed by fourteen eastern banks, ${ }^{279}$ and the Western States Bank Card Association ("WSBCA") was formed by four big Califor-

269

Id. at 92-109 (describing spin-off).

Id. at 159-160 (describing name change).

271 EVANS \& SCHMALENSEE, supra note 1 , at 157.

272 CHUTKOW, supra note 4, at 117.

273 The interchange fee compensates the issuer bank "for the 'free' period between settlement, or payment, to the acquirer (the merchant bank) for cardholder purchases and billing to cardholders." Olsen, supra note 156 , at 17.

274 Evans, supra note 81, at 375-76 ("Members of cooperative systems such as MasterCard and VISA compete for cardholders and merchants. Absent coordination there is no way for these members to determine pricing structure and thereby internalize the indirect network externalities created by merchants for cardholders and vice versa. A centrally set interchange fee enables the cooperatives to establish a pricing structure.") (citations omitted).

275 See Evans \& Schmalensee, supra note 86, at 889-90.

276 To be specific, under the assumption of 15,000 financial institutions and a target of $100 \%$ coverage, there would be 15000 ! (factorial) individual contracts.

277 EVANS \& SCHMALENSEE, supra note 1, at 65-66.

278 CHUTKOW, supra note 4 , at 70.

279 Id. at 70. 
nia banks. By the end of the 1960s the WSBCA became MasterCharge. ${ }^{280}$ In the 1970s, the regional associations began to merge into larger, more national and even international associations. ${ }^{281}$

The association approach differed from Bank of America's approach in that, rather than licensing an asset to another bank, members in the association contributed assets (e.g. access to their merchant and consumer portfolios) to the association, receiving back reciprocal access to the other members' merchant portfolios. There were also similarities. The associations implemented fee structures for transactions out of a bank's card portfolio in another member bank's merchant portfolio that paralleled Bank of America's charges for the use of Bank of America's merchant portfolio.

One major change in the association structure came in 1976 when antitrust regulators forced a change in both associations' rules that prohibited members from participating in both. ${ }^{282}$ With those rules withdrawn, many banks joined both associations. ${ }^{283}$ Today VISA and MasterCard are both owned by many of the same banks, although the percentage share each bank has in the two networks may vary. Despite this overlap in ownership, the networks are extremely competitive. ${ }^{284}$ Today the competition is largely on the card issuer side, with a few banks and non-banks dominating the merchant acquirer business. ${ }^{285}$ In the $1990 \mathrm{~s}$, non-banks began to enter the credit card issuer market. Companies like AT\&T, General Motors and others created co-branded cards through partners and financial subsidiaries. ${ }^{286}$

Although the major event of the 1970s was the rise of the two national associations, MasterCard and VISA, proprietary networks continued to thrive as well. Not only did Diners Club and American Express expand out of their original market niches among the Manhattan elites, ${ }^{287}$ other proprietary networks (e.g. gasoline and department store cards) also grew. ${ }^{288}$ In-

280 Id. According to Robert D. Manning, the Western States Bank Card Association, the Interbank Card Association, and the Midwest Bank Card Association were all specifically formed as a response to Bank of America's licensing of BankAmericard. And, later, Western States Bank Card Association became MasterCharge. See Robert D. MANNING, CREdT Card Nation: The Consequences of AMERICA'S ADDICTION TO CREDIT 84 (2000).

281 WSBCA first licensed its know-how to Europay in Europe, ultimately merging with it in the 1970s. See CHUTKOW, supra note 4, at 224-27 (on rise of Visa International).

282 EVANS \& SCHMALENSEE, supra note 1, at 69-70 ("Faced with an ambivalent Antitrust Division [of the Department of Justice] and the possibility of expensive litigation, Visa removed all restrictions on dual membership in mid-1976.").

283 Olsen, supra note 156, at 19 ("Duality has eliminated most of the profits from the merchant business" due to competition.).

284 EVANS \& SCHMALENSEE, supra note 1, at 70-71 ("Considerable competition" between networks explained).

285 Olsen, supra note 156, at 19.

286 Cynthia R. Whiteman, Marketing, in AMERICAN BANKers Association, The Bank Credt CARD BUSINESS 38, 39 (2d ed. 1996).

287 EVANS \& SCHMALENSEE, supra note 1 , at 85.

288 Id. at $85-94$ 
deed, new closed networks have regularly appeared since then, the largest and most widely recognized of which was the creation of Discover by Sears, Roebuck \& Co. in 1985..$^{289}$

By the 1970s, the proprietary bank card world of the 1950s and 1960s was transformed. VISA and MasterCard's innovations in both business model and technology had reduced transactions costs to a fraction of Diners Club's and American Express's initial charges, association networks linked merchants and consumers, association rules governed virtually every aspect of transactions, and advances in credit reporting began to make it possible for issuers to track the reputation of their customers. Issuers and merchant acquirers competed for business by cutting costs and innovating to improve the quality of their products.

\section{The Modern Era}

Since the 1970s, the evolution of card-based payment systems has increased in pace. Important security features, which reduce fraud, and features which reduce errors and speed processing appeared during the $1970 \mathrm{~s},{ }^{290}$ including the introduction of the magnetic strip on the back of the card in the $1970 \mathrm{~s},{ }^{291}$ which facilitates swiping the card through an electronic mechanism, reducing errors in transactions and increasing security. New anti-fraud technology continued to appear, such as the addition of the CVV and CVV2 numbers in the 1990s. ${ }^{292}$ Holograms on cards were introduced in 1983, making it harder to counterfeit. ${ }^{293}$ Tamper resistant signature panels on the back of cards were introduced in 1989.294

Perhaps the two most important technological developments were the appearance of PIN-based debit cards in the $1980 \mathrm{~s}^{295}$ and the shift to electronic processing in the mid-1970s. ${ }^{296}$ As noted earlier, debit cards operate on a single message system, combining the authorization and settlement

\footnotetext{
289 Id. at 281.

290 See CHUTKOw, supra note 4, at 153-54 (describing development of computer systems to reduce fraud losses).

291 See Jim Collins, Hidden Identity, ATTACHÉ (June 2004), available at http:// www.attachemag.com/archives/06-04/informed/infos 1.htm (describing history of magnetic strip).

292 These numbers are created by proprietary formulas by issuers; the association rules in open associations specify how complex the formulas must be.

293 ChuTKow, supra note 4, at 183.

294 MasterCard, History of Firsts, http://www.mastercardinternational.com/corporate/history _firsts.html (last visited April 23, 2005).

295 EVANS \& SCHMALENSEE, supra note 1, at 297-302 (describing growth of the debit card).

296 VISA introduced electronic processing in 1973 and American Express and MasterCard soon followed. CHUTKOW, supra note 4, at 158-159. See also EVANS \& SCHMALENSEE, supra note 1, at 176 ("[P]erhaps the most important series of innovations that have taken place over time have involved improvements in processing transactions.").
} 
messages into a single transaction. ${ }^{297}$ Electronic processing made card based systems less like check processing and allowed innovations such as the introduction of real time authorization and rule-based systems for detecting potential fraud..$^{298}$

One key aspect of many of the innovations in the industry is that they reduce fraud. The burden of fraud had been contractually shifted to the merchants by the merchant acquirers. Indeed, since the financial institutions write the rules, they have every incentive to shift losses to others. Yet card-based payment systems continue to innovate to reduce losses that no party to the association contract bears. Moreover, the industry continues to be highly competitive, ${ }^{299}$ with competition regularly appearing in new areas and in driving new technologies. For example, the associations make use of financial incentives to encourage the adoption of new technologies, with interchange fees varying with the merchant's authorization mechanism (e.g. POS terminal, allowing rapid settlement, or paper). ${ }^{300}$ Moreover, while the 1990s saw a great deal of consolidation among financial institutions ${ }^{301}$ and technical services companies' operating networks, ${ }^{302}$ it also saw the rise of independent sales organizations (ISO). Historically the ISOs acted as sales arms of merchant acquirers, going door to door from merchant to merchant

\footnotetext{
297 See supra notes 136-137.
}

298 For example, the Falcon system, originally developed by HNC from technology utilized to recognize friendly tanks on the battlefield, compares authorization requests against the prior use pattern for that specific card holder. Thus if a card holder has not traveled internationally in the past ten years use of her card overseas is more likely to trigger a real-time hold or a post transaction alert (depending on the fraud and risk control policies of the issuer) than if she has frequently traveled outside her home country in the past. If the card holder has never made a major jewelry purchase, then a request for authorization for a significant purchase at a jeweler's is more likely to trigger a real-time hold or a post transaction alert than if the cardholder frequently purchases jewelry. See http://www.fairissac.com (for a description of Falcon; HNC was purchased by Fair Issac.). See also CHUTKOW, supra note 4, at 188 89 (describing VisaNet's similar system). By comparison, prior to the development of electronic verification,

"authorizations involved checking an account number against numbers listed on a merchant waming bulletin. Putting a number on a merchant warning bulletin could take several weeks. And even after the listing, so long as the delinquent customer kept he amount of purchase below the floor limit, the merchant had no way of knowing that the cardholder's charge privileges had been suspended. Delinquent borrowers could make numerous purchases of this nature before the account appeared on the bulletin."

AURIEMMA, supra note 5, at 10.

299 The modem era is also marked by fierce competition among networks. See, e.g.. FRIEDMAN \& MEEHAN, supra note 95, at 110-111 (describing American Express's competition with VISA and MasterCard in the 1980s); id. at 253-54 (describing competition for merchants with VISA and MasterCard, especially the 1991 restaurant "revolt" in Boston).

300 Olsen, supra note 156, at 17.

301 See Simon Kwan, Banking Consolidation, FRBSF ECONOMIC LETTER, June 18, 2004, available at http://www.frbsf.org/publications/economics/letter/2004/el2004-15.pdf.

302 First Data, for example, has an impressive market share and continues to expand. See Olga Kharif, Why First Data Is Ready to Roll, Bus. WK., Jan. 5, 2004, available at http://yahoo .businessweek.com/bwdaily/dnflash/jan2004/nf2004015_7492_db014.htm. 
convincing the merchants to sign contracts with the merchant acquirer the ISO represented. More recently, however, ISOs used their relationships with merchants to persuade merchants to accept ISO-owned ATM machines in the merchant's facilities. These ATM machines route their transactions through a merchant acquirer via a contract between the ISO and the merchant acquirer. ${ }^{303}$ The ISOs have thus introduced a new form of competition. Similarly, the growth of firms such as First Data provides the associations with potential competition across networks. ${ }^{304}$ Network competition suggests the continuation of substantial differences in services across the networks. ${ }^{305}$

\section{Competition-Driven Evolution}

At some points in time, the evolution of card-based payment systems appears to be the paradigmatic story of an industry evolving into oligopoly. A fiercely competitive market of individual small players competes itself to the point of bankruptcy, consolidates into a few major players (the associations, American Express), and then imposes detailed rules on the entire industry. Just another "dog bites man," or, rather, a "capitalist bites consumer" tale- one of many told in the legal academy.

Closer examination reveals the dominance of competition at virtually every turn. Competition drives MasterCard and VISA, despite the common ownership of the two networks. Competition drives individual banks within both associations. Competition drives American Express to challenge VISA and MasterCard and vice versa. Competition drives First Data to build a network that could challenge the associations. We think it is fair to conclude, therefore, that the card-based payment systems market has as its primary characteristic competition. This competition is aimed at making money. To make money, the various players in the industry have harnessed reputational capital and technology to reduce losses. As a byproduct of this effort they have created a dispute resolution system that offers important advantages over public court systems.

\footnotetext{
303 The merchant acquirer must be a bank and a member of the network through which the ISO wishes to route the transactions.

304 See supra notes 142-50.

305 EVANS \& SCHMALENSEE, supra note 1, at 151 ("When network externalities are important, multiple networks that do not interconnect can survive only if they are offering consumers substantially different services. In the case of payment cards, multiple networks exist in part because these networks offer consumers and merchants somewhat different products.").
} 


\section{E. Regulation-Driven Evolution}

In this section, we review the interrelationship among the private dispute resolution system and some of the impacts of federal regulation of lending. In 1968, Congress passed the Consumer Protection Act; ${ }^{306}$ the components most relevant for this analysis are the sections that are now referred to as the Truth-In-Lending Act (TILA). This act attempted to protect consumers by providing more transparent and clear disclosure of terms and conditions associated with lending transactions. ${ }^{307}$ (Its success in achieving this is open to question.) Over the years, this act has been amended to expand the protections beyond the disclosure of key terms, rates, and fees. ${ }^{308}$ Using the regulatory authority granted to it by the TILA, the Board of Governors of the Federal Reserve System adopted Regulation Z. ${ }^{309}$ Both the TILA provisions and corresponding Regulation $Z$ provisions directly regulate some aspects of card-based payment systems' dispute resolution systems. ${ }^{310}$ Three provisions are particularly relevant.

First, the TILA and Regulation Z limit the liability of the holder of a credit card to $\$ 50$ for unauthorized charges. ${ }^{311}$ Capped liability thus fre-

306 Truth-In-Lending Act, Pub. L. 90-321, May 29, 1968 [hereinafter, TILA] 15 USC 1601 et seq.

307 Financial institutions complied with the extensive disclosure requirements by providing the mandatory notices and explanations. Consumers and even lawyers have not reacted well to these extensive disclosures mandated by the act. Harvard Law Professor Elizabeth Warren, a noted expert on contract law, claimed on public television that "I have read my credit card agreement, and I can't figure out the terms. I teach contract law. And, the underlying premise of contract law is that the two parties to the contract understand what the terms are." See Frontline: Secret History of the Credit Card, Chapter Three, "Credit Reporting Agencies / Traps in the Fine Print", (PBS television broadcast Jan. 2005), http://www.pbs.org/wgbh/frontline/shows/credit/view. A discussion of whether the extensive disclosure requirements of this act should be repealed to enable better and clearer contracts is beyond the scope of this analysis on dispute resolution. See Richard Hynes \& Eric A. Posner, The Law and Economics of Consumer Finance, 4 AM. L. \& ECON. REV. 168, 193-95 (2002) (analyzing TILA provisions).

308 In 1974, protections were added for inaccurate and unfair credit billing and credit card practices. Pub. L. 93-495, Oct. 28, 1974. In 1980, the act was reorganized and some requirements were eliminated. Pub. L. 96-221, Mar. 31, 1980. Further changes that are beyond the scope of this analysis were made in the decades that followed. See Pub. L. 104-12, Mar. 19, 1995 (changes to class action suits under this act). See also Pub. L. 104-29, Sept. 30, 1995.

309 See 12 C.F.R. 226 (known in the industry as Regulation $Z$ or sometimes Reg Z).

310 See 15 U.S.C. $\$ 1643$ (2005) Liability of the holder of a Credit Card; 15 U.S.C. $\$ 1666$ (2005) Correction of Billing Errors; and 15 U.S.C. $\$ 1666 \mathrm{i}$ (2005) Assertion by cardholder against card issuer of claims and defenses. Within $\operatorname{Reg} Z$, these key sections are implemented through, respectively: Liability of cardholder for unauthorized use (12 C.F.R. § 226.12(b)); Billing Error Resolution (12 C.F.R. \& 226.13); and Right of Cardholder to assert claims and defenses against the Issuer (12 C.F.R. $\S$ $226.12(\mathrm{c}))$.

31115 U.S.C. $\S 1643$ ( "A cardholder shall be liable for the unauthorized use of a credit card only if - (A) the card is an accepted credit card; (B) the liability is not in excess of $\$ 50$; (C) the card issuer gives adequate notice to the cardholder of the potential liability; (D) the card issuer has provided the cardholder with a description of a means by which the card issuer may be notified of loss or theft of the card .... .); ("(b) Liability of cardholder for unauthorized use-(1) Limitation on amount. The liability 
quently turns on what is actually authorized by the cardholder. ${ }^{312}$ The courts have largely interpreted this to put absolute responsibility on the issuer to know and understand its consumer's intent, and therefore, if there is a question about authorization, the issuer has generally been held liable. ${ }^{313}$

As a result, issuers implemented rules, processes, and technologies to enable them to prove that the cardholder authorized the transaction. For example, to comply with the notification method component of the statute, issuers placed a "Lost/Stolen" telephone number on the reverse side of every card. To ensure that the end consumer actually physically received a card, when issuing and mailing out new credit cards, issuers implemented card activation technologies that required the recipient to take steps to prove to the issuer that the card had been received by the intended recipient. ${ }^{314}$ In addition, sometimes the issuer will contact the cardholder after the first purchase using a new card, to ensure that the intended consumer actually made that purchase.

Later, if and when a consumer initiates a dispute with the complaint that a charge was not authorized, these processes and technologies can either support or refute the consumer's claim with additional information. For example, in the initiation of the dispute, if the consumer claims that she never received the card, the issuer will check the activation records. If that card was activated from the cardholder's phone number, the issuer knows

of a cardholder for unauthorized use of a credit card shall not exceed the lesser of $\$ 50$ or the amount of money, property, labor, or services obtained by the unauthorized use before notification to the card issuer under paragraph (b)(3) of this section.") Reg Z defines "unauthorized use" as "the use of a credit card by a person, other than the cardholder, who does not have actual, implied, or apparent authority for such use, and from which the cardholder receives no benefit." 12 C.F.R. $\$ 226.12(\mathrm{~b})$ ).

312 See Universal Bank v. McCafferty, 88 Ohio App.3d 556 (1993), 624 N.E.2d 358 (McCafferty not liable on friend's charges when issuer sent card to friend at McCafferty's request because McCafferty did not authorize friend's use of the card). The sentence construction of the act starts with the declarative statement "the cardholder shall be liable for unauthorized use of a credit card only if" and then provides a laundry list of requirements. The laundry list utilizes the conjunctive "and" between each of the provisions to indicate when a consumer is actually liable for an authorized charge. Arguably therefore, if any of the items on the laundry list fail to be true, then AND the charge is unauthorized, the cardholder cannot be held liable. Therefore, liability typically turns on authorization.

313 See discussion supra note 312.

314 The service works because a card mailed to a consumer is not "live" in the sense that the card cannot be utilized to make purchases until the consumer activates it through an activation process offered by the issuer financial institution. Although not foolproof, this activation service employs various technologies to ensure that the person receiving the card, did in fact receive the card. For example, most card activation systems require the consumer to dial a toll-free 800 style number and answer a few questions with a computer known as an Interactive Voice Response Unit. Questions may request the consumer's social security number, birth date, and other information that is not generally known. This computer also utilizes the Automated Number Identification service to collect secondary information from the phone company. Automated Number Identification is roughly equivalent to Caller Id. The incoming telephone number from the Card Activation Call is then matched and cross referenced to the telephone number on the card application and to the name the phone company has on record. 
that someone in the household activated the card, perhaps even the cardholder. ${ }^{315}$ And, if the issuer has held a previous conversation with the consumer about her first purchase, it will be much more difficult for the consumer to claim they never received the card.

A second important regulatory measure is the requirement that issuers correct billing errors. ${ }^{316}$ Simply stated, this provision requires the card issuer to credit the consumer cardholder's account and investigate the problem when it receives a complaint about a billing error. If the consumer validates that the charge is actually correct, the correction process is undone and the charge is reinstated onto the consumer's account. The statute uses an expansive definition of billing error, including many types of claims beyond accounting and mathematical errors in the definition. ${ }^{317}$

315 Although possible, it is highly unlikely that a card thief would break into a house solely to complete the card activation from the actual consumer's home phone number.

31615 U.S.C. $\$ 1666$ (2005) (Written notice by obligor to creditor; time for and contents of notice; procedure upon receipt of notice by creditor: "[I]f a creditor, within sixty days after having transmitted to an obligor a statement of the obligor's account in connection with an extension of consumer credit, receives . . . a written notice . . . from the obligor in which the obligor- (1) sets forth or otherwise enables the creditor to identify the name and account number (if any) of the obligor, (2) indicates the obligor's belief that the statement contains a billing error and the amount of such billing error, and (3) sets forth the reasons for the obligor's belief . . the creditor shall, unless the obligor has, after giving such written notice and before the expiration of the time limits herein specified, agreed that the statement was correct- (A) not later than thirty days after the receipt of the notice, send a written acknowledgment thereof to the obligor, unless the action required in subparagraph (B) is taken within such thirty-day period, and (B) not later than two complete billing cycles of the creditor (in no event later than ninety days) after the receipt of the notice and prior to taking any action to collect the amount, or any part thereof, indicated by the obligor under paragraph (2) either- (i) make appropriate corrections in the account of the obligor, including the crediting of any finance charges on amounts erroneously billed, and transmit to the obligor a notification of such corrections and the creditor's explanation of any change in the amount indicated by the obligor under paragraph (2) and, if any such change is made and the obligor so requests, copies of documentary evidence of the obligor's indebtedness; or (ii) send a written explanation or clarification to the obligor, after having conducted an investigation, setting forth to the extent applicable the reasons why the creditor believes the account of the obligor was correctly shown in the statement and, upon request of the obligor, provide copies of documentary evidence of the obligor's indebtedness.") See also 12 C.F.R. $\$ 226.13$.

31715 U.S.C. $\S 1666$ ("For the purpose of this section, a "billing error" consists of any of the following: (1) A reflection on a statement of an extension of credit which was not made to the obligor or, if made, was not in the amount reflected on such statement. (2) A reflection on a statement of an extension of credit for which the obligor requests additional clarification including documentary evidence thereof. (3) A reflection on a statement of goods or services not accepted by the obligor or his designee or not delivered to the obligor or his designee in accordance with the agreement made at the time of a transaction. (4) The creditor's failure to reflect properly on a statement a payment made by the obligor or a credit issued to the obligor. (5) A computation error or similar error of an accounting nature of the creditor on a statement. (6) Failure to transmit the statement . . to the last address of the obligor which has been disclosed to the creditor, unless that address was furnished less than twenty days before the end of the billing cycle for which the statement is required. (7) Any other error described in regulations of the Board."). 
So, in the dispute resolution process, the issuer will classify a consumer dispute that is brought ${ }^{318}$ under this section of the TILA and Regulation $\mathrm{Z}$ according to the association rules. As described earlier, each dispute classification will initiate specific process steps and information gathering needs. With the exception of non-delivery of goods or the statement itself, the TILA requirements affect disputes which require the sales receipt from the merchant. A billing error ultimately leads to either a consumer who denies making or simply does not recognize the charge, or to a dispute in which the amount is incorrect. ${ }^{319}$ Therefore, a retrieval request, as described earlier, is initiated to provide the information necessary to resolve these classes of disputes. ${ }^{320}$ Under the TILA provisions, consumers are time limited to raising billing error disputes to sixty days from the statement mailing date. $^{321}$ TILA also bars issuers from assessing interest or penalties on disputes or reporting the disputes to credit bureaus until the dispute resolution process is completed.

The third important TIA impact comes from its provisions permitting cardholders to assert claims and defenses against card issuer provisions. ${ }^{322}$

318 Of course, a consumer is unlikely to indicate that they are making a claim under the Billing Errors section of the Truth in Lending Act. Rather, that consumer will simply call the issuer and complain that the charges are incorrect. The issuer will classify the complaint.

319 Sometimes the "tip" amount at restaurants is incorrect. Therefore, the consumer recognizes the restaurant charge, but does not recognize the total amount, as accurate.

320 Of course, if the merchant does not respond to the retrieval request, the merchant may ultimately lose a chargeback dispute and the credit to the consumer's account will become permanent. If the retrieval request produces a receipt that the consumer recognizes and accepts as legitimate, the charge is reinstated onto the account and the process ends. Or, the remainder of the dispute resolution process is followed, as described above.

321 Given the timing of any particular card charge item and the printing of the statement, the consumer probably has closer to ninety days from the date of the actual charge to complain about an error.

32215 U.S.C. \$ 1666i (2005) ("(a) Claims and defenses assertable. Subject to the limitation contained in subsection (b), a card issuer who has issued a credit card to a cardholder pursuant to an open end consumer credit plan shall be subject to all claims (other than tort claims) and defenses arising out of any transaction in which the credit card is used as a method of payment or extension of credit if (1) the obligor has made a good faith attempt to obtain satisfactory resolution of a disagreement or problem relative to the transaction from the person honoring the credit card; (2) the amount of the initial transaction exceeds $\$ 50$; and (3) the place where the initial transaction occurred was in the same State as the mailing address previously provided by the cardholder or was within 100 miles from such address, except that the limitations set forth in clauses (2) and (3) with respect to an obligor's right to assert claims and defenses against a card issuer shall not be applicable to any transaction in which the person honoring the credit card ... (E) has obtained the order for such transaction through a mail solicitation made by or participated in by the card issuer in which the cardholder is solicited to enter into such transaction by using the credit card issued by the card issuer. (b) Amount of claims and defenses assertable. The amount of claims for defenses asserted by the cardholder may not exceed the amount of credit outstanding with respect to such transaction at the time the cardholder first notifies the card issuer or the person honoring the credit card of such claim or defense.") See also 12 C.F.R. $\$ 226.12$ (2005). Note that the implementing regulations specifically exclude debit cards and similar non-credit cards. Although the statute is based on the extension of credit, the question of what is a credit card is left unan- 
The statute and regulations provide that a cardholder may assert a claim or defense on the underlying transaction to the issuer, if that cardholder has first made a good faith attempt to resolve the dispute with the merchant. Note that the assertion of a claim or defense on the underlying transaction is mutually exclusive with authorization or billing error disputes, described above. So, in asserting a claim or defense, the consumer is admitting that the transaction occurred, and that the consumer authorized that transaction.

The net effect of TILA and Regulation $\mathrm{Z}$ is to shift responsibility associated with the payment system away from the consumer toward the financial institution that issues that card. Ultimately, however, the issuer does not actually bear the costs associated with these disputes. By contract and rule, losses associated with disputes that the cardholder wins are shifted to the acquirer and ultimately to the merchant, and thence to the consumer through higher prices. ${ }^{323}$

Federal regulation, through TILA and Regulation $\mathrm{Z}$, has had an impact on card-based payment systems' dispute resolution mechanisms. The regulatory provisions described above provided reasons for the development of particular provisions in those dispute resolution systems. We are unconvinced, however, that either TLA or Regulation $\mathrm{Z}$ deserves more than minimal credit for the success of the card-based payment systems' dispute resolution procedures. ${ }^{324}$ Regulation mandated a limit on consumer card losses, provided incentives for some minor card features (e.g. the 800 "lost or stolen" number on the back), and required some procedure to assert defenses against charges.

It is far from clear, however, that these provisions (or something like them) would not have been adopted in response to competitive pressures. As we described earlier, the early credit cards were particularly vulnerable to fraudulent use, as issuers exercised little to no control over the credit worthiness of cardholders and made indiscriminate mailings of cards. Fraud prevention measures resulted in the first instance from the financial losses experienced by issuers as a result of fraud. Moreover, since consum-

swered. There is a legitimate argument that a debit card would fit into the credit focus of the statute because there are temporary extensions of credit granted in the payment process of moving money through the chain of participants from a consumer, through a debit card issuer, an association, a debit card acquirer, and ultimately to a merchant's settlement account.

323 Of course, if the dispute resolution processes that the associations have implemented lead to an accurate result, the merchant would have had to pay these damages anyway except that the consumer would have had to resort to formal public legal means, including lawyers' fees and potentially punitive damages.

324 Much of the legal literature seems to accept that Regulation $\mathrm{Z}$ is responsible for the success of the dispute resolution system. See, e.g., Jane K. Winn, Making XML Pay: Revising Existing Electronic Payments Law to Accommodate Innovation, 53 S.M.U. L. REV, 1477, 1491-92 (2000) ("Regulation Z provides not merely a billing error resolution procedure and protection from liability for unauthorized use of the credit card, but it also provides a simple and effective alternative dispute resolution process in the event the consumer is unhappy with the transaction itself."). 
ers had to be persuaded initially to adopt credit cards as a means of payment and since competing payment systems were less vulnerable to fraud (e.g. checks, cash), adoption of dispute resolution provisions and antifraud measures generally (although not any particular provision) would have been compelled by market pressures. ${ }^{325}$ Finally, the major card networks have extended provision of dispute resolution procedures internationally, well beyond the reach of Regulation Z ${ }^{326}$ Similarly, domestic debit card networks and issuers have generally provided equivalent dispute resolution procedures, despite the inapplicability of Regulation $\mathrm{Z}$, to protect their brand names. ${ }^{327}$ We conclude, therefore, that TILA and Regulation $\mathrm{Z}$ had some impact on the shaping of the dispute resolution systems associated with card-based payment systems, but the regulatory impact was less important than the impact of competition.

\section{CONCLUSION}

We opened this paper by proposing a "radical rethinking of dispute resolution" based on card-based payment systems' dispute resolution procedures. Those who have read this far (without skipping!) would undoubtedly like to know what that radical rethinking is.

Card-based payment systems' procedures for resolving disputes look nothing like the procedures used by the public legal system. In place of lawyers, judges, and juries, card-based payment systems use clerical employees, simple processes, and technology. In place of notice pleading, they use something that more closely resembles the old common law forms of action than anything else we have encountered in the modern world. In place of liberal discovery rules, they use restrictive rules providing for limited discovery. In place of clever lawyering, they use structured, semiautomated interviews. Despite all these differences, card-based payment systems' dispute resolution systems do not seem to be sparking any signifi-

325 EVANS \& SCHMALENSEE, supra note 1, at 324 ("Payment cards have not flourished just because they provide a convenient alternative to cash and checks. Over time, entrepreneurs have discovered that they can integrate other products and services into payment cards and thereby make these cards more valuable for consumers and merchants.").

326 See, e.g., FTC filings by VISA and American Express quoted in Perritt, supra note 42, at 690, n.70 (quoting VISA Senior Vice President that 'The chargeback reasons permitted under VISA's rules for international transactions have been adopted to enable issuers of VISA cards to address the fundamental consumer concerns of their cardholders, and incidentally to reinforce the reputation of VISA Cards as the best way to pay" and quoting American Express Group Counsel that "'[w]hile U.S. law requires us to institute these practices, as a card issuer, we have adopted a policy of applying them consistently outside the U.S. as well.").

327 See Balto, supra note 63, at 1104-05 (describing voluntary steps by VISA and MasterCard; although Mr. Balto does not see these steps as sufficient and calls for regulation, we disagree with his assessment.). 
cant consumer or merchant revolts. Either the systems do not harm consumers or merchants, or any harm they cause is overwhelmed by the benefits of the system. ${ }^{328}$ There is, therefore, some evidence that consumers and merchants alike accept this sort of system.

Is it better? The systems we describe above handle a high volume of disputes (generally low value disputes, to be sure) and handle them quickly and cheaply. For at least some classes of disputes, therefore, we think this type of system is clearly better, so long as we define "better" as "cheaper." While we are sensitive to the traditional claims that the legal system serves a higher function of justice, fairness, and consistency, rather than to simply cheaply resolve disputes among private parties, we are also skeptical about the frequency with which that argument is used to justify what appears to be rent-seeking by those with an interest in the current public legal system (lawyers, legislatures, judges, etc.) ${ }^{329}$

We think the card-based payment systems model is better in ways other than being simply cheaper. In particular, the model provided by cardbased payment systems is better for disputes which arise from the strategic behavior of one or more of the parties. Such behavior is rampant in the public legal system because of the structure of the litigation process. ${ }^{330}$ Because these systems incorporate information about disputes generally, as well as about specific parties, they are better able to identify and correct strategic behavior by disputants. Moreover, because the card-based payment systems can change the rules governing the use of the cards, card issuers can learn from present disputes how to avoid future disputes and implement new rules which prevent such disputes from arising in the future.

One of the reasons the card-based payment systems' dispute resolution systems succeed may initially appear counter-intuitive for law professors (at least it did for the ones who coauthored this piece). By simplifying disputes into categories and then applying managerial expertise to ruthlessly drive down costs, these dispute resolution systems not only do not use lawyers, they have no room for them. As Professor Hadfield notes, "Brilliant

328 If the dispute resolution systems did harm either consumers or merchants but left net benefits positive, presumably competitive pressures would push some card to offer superior dispute resolution. Dean Perritt reaches a similar conclusion from his observation of disputes: "Although good empirical data is lacking, it appears that the system satisfies both consumers and merchants. Almost no reported cases in the regular courts exist, suggesting that consumers rarely are motivated to go beyond the chargeback process to more formal forms of dispute resolution." Perritt, supra note 42, at 691 .

329 Astoundingly, one article referred to the American Bar Association as "one of the few neutral, non-stakeholding but nongovernmental or intergovernmental entities" involved in dispute resolution, despite acknowledging that "a portion of its members are obviously interested in the provision of ADR services and therefore have some vested interest." Louise Ellen Teitz, Providing Legal Services for the Middle Class in Cyberspace: The Promise and Challenge of On-Line Dispute Resolution, 70 FORDHAM L. REV. 985, 1005 (2001).

330 Hadfield, supra note 11, at 972 ("The process of litigation is a series of strategic moves and countermoves: sophisticated moves require even more sophisticated responses."). 
lawyering is the art of drawing out and then persuading others of the saliency of distinctions and similarities that were not previously recognized." 331 The essence of the dispute resolution systems described here, however, is that they reject the introduction of "distinctions and similarities" not embedded in the rules. In short, if there is no code for a dispute, there is no dispute..$^{332}$ If there is a code, everything from the acceptable evidence to the time limits for the process are dictated by the code. The code is applied not by a highly trained lawyer, but by a clerk. We think this is critical to reducing the costs of dispute resolution. ${ }^{333}$ Moreover, card-based systems' reliance on simple procedures eliminates an important cost to complexity: the difficulty of explaining complex systems to consumers. ${ }^{334}$ Professor Hadfield raises an important point about such solutions. After identifying complexity as a key problem in the public legal system, ${ }^{335}$ she notes that while reducing complexity is a natural area for improvements, doing so raises "deep philosophical and practical questions which all come down to this: is legal reasoning, as we know it, what law and justice is?"336 We are not sure that it is. After talking with many participants in the dispute resolution system of card-based payment systems, both on and off the record, we do not see injustice in its often inflexible rules. In other words, adding lawyers to the process would not obviously lead to an improvement in any dimension.

The card-based payment systems' dispute resolution processes described here do not meet the traditional public legal system-oriented definition of due process. ${ }^{337}$ For example, Judge Henry J. Friendly defined eleven

331 Id. at 966.

332 In a sense, we are echoing the "most significant principle to emerge from the academic study of law on the Internet . . the ideas that software code . . is broadly substitutable for legal code . . Code is law; architecture is control; software is power." R. Polk Wagner, On Software Regulation, 78 S. CAL. L. REV. 457, 459 (2005).

333 Prof. Hadfield notes that "the hours required to resolve a legal matter are not fixed by abstract and immutable principles of justice. They are determined by the procedures and reasoning requirements established and implemented by members of the profession (lawyers and judges and legislators) in an antagonistic, interactive process." Hadfield, supra note 11 , at 965 . It is by the use of forms and procedures that the card-based payment systems are able to control the dynamic to complicate disputes that Hadfield observes in the public legal system.

334 This simplification is a significant concern of "consumer advocates" in their critiques of alternative dispute resolution systems. See, e.g., Krause, supra note 6, at 480 ("Many consumer advocates voice one central, underlying concern. At what point does the imposition of a private dispute-resolution requirement place too big a burden on the average consumer. That is, when is the sophistication and savvy of the average Internet user not enough to level the playing field.").

335 Hadfield, supra note 11, at 995 ("The complexity of legal reasoning and process is fundamental to the entire market. It is the source of direct cost, as we have seen. But more importantly it plays a central role in a host of indirect distortions.").

336 Id. at 1002.

337 For example, Prof. Gibbons is critical of arbitration in the consumer context because it is 'unfair': limited discovery, lack of a jury trial or a right to appeal, repeat-player advantages in selecting arbitrators, no class relief, and excessive fees unfairly disadvantage individuals bringing claims." Gib- 
elements of procedural due process as: (1) an unbiased decision maker; (2) notice and a statement of the reasons for the initial action that causes the dispute; (3) an opportunity to present reasons why the action should not be taken; (4) an opportunity to present evidence, including witnesses; (5) the right to know opposing evidence; (6) the right to cross-examine opposing witnesses; (7) limiting the decision to the evidence in the record; (8) the right to be represented by counsel; (9) a record of evidence prepared by the decision maker; (10) the decision maker gives reasons for the decision; and (11) the availability of appellate review. ${ }^{338}$ Some have argued that these elements should also apply, at least in part, to non-judicial forms of dispute resolution. ${ }^{339}$

Many of Friendly's eleven elements do not apply to the card-based payment systems' dispute resolution processes. There is no right to counsel, no opportunity to cross-examine opposing witnesses, no right to know opposing evidence, no record available to the parties, and no written decision given to parties stating reasons for the decision. Moreover, it is at least arguable that the decision maker is insufficiently neutral to qualify in Friendly's definition, or that either the record or the internal appeals process would satisfy his definitions. At most, therefore, six of his eleven criteria are satisfied and possibly as few as four. Rather than forming a basis for condemning the card-based payment systems, we suggest that these differences should prompt a radical rethinking of the value of traditional due process in dispute resolution. In the case of card-based payment systems' dispute resolution procedures, we conclude that the incentives provided by competition serve as an effective substitute for formal procedural due process structures.

Another criticism of card-based systems is that consumers lack information or the incentive to bargain with card issuers, making government regulation necessary to even the playing field. ${ }^{340}$ We contend that such arguments fail to grasp the power of competition to induce fair outcomes. In the case of card-based payment systems, the competitive pressures on card issuers, the introduction of merchant acquirers as repeat players, and networks' role provide incentives for card issuers to treat cardholders fairly without requiring cardholders to invest in knowledge about the details of

bons, supra note 49, at 15. See also Lucille M. Ponte, Boosting Consumer Confidence in E-Business: Recommendations for Establishing Fair and Effective Dispute Resolution Programs for B2C Online Transactions, 12 AlB. L.J. SCI. \& TECH. 441 (2002) (describing an elaborate set of principles proposed by the American Arbitration Association's National Consumer Disputes Advisory Council, few of which are met by the card-based systems).

338 Henry J. Friendly, Some Kind of Hearing, 123 U. PA. L. REv. 1267, 1279-95 (1975).

339 See Perritt, supra note 42, at 679-83.

340 See, e.g., Effross, supra note 62, at 376 ("given consumers' lack of incentive or knowledge to bargain, and likely reluctance to litigate, especially where their adversaries would tend to be sophisticated financial institutions and the amount at issue relatively small, federal regulation is warranted.") (citations omitted). 
the system. Demanding that such systems replicate the institutions of the public legal system only ensures that they cannot innovate and so will have the same general failings and successes as the public system.

Consider for example the idea of an unbiased decision maker. In the public legal system this is ensured by providing the judiciary with independence. ${ }^{341}$ In card-based systems it is provided by the competitive pressures on the networks by other networks. For example, if a network treats a merchant acquirer or issuer unfairly on a regular basis, that entity will switch its allegiance generally, or a greater share of its transactions, to a competing network and issuers and merchant acquirers who treat cardholders or merchants unfairly will lose market share to competitors.

Lawyers have generally been able to maintain control of alternatives to the public legal system because most alternatives depend upon the public legal system to enforce their decisions. ${ }^{342}$ Card-based systems show that this need not be true where the dispute resolution mechanism is part of a good or service desired independently. Merchants and consumers (usually) accept the results of the dispute resolution process because they want to continue to participate in the payment system. Instances in which either seek redress in the courts are relatively rare, (admittedly a judgment largely based on the infrequency of reported opinions, given the number of cards, merchants, and cardholders). Moreover, the card-based payment system actors (issuers, acquirers, networks, card companies) profit by using their dispute resolution procedures to lure customers to their networks. ${ }^{343}$

The strength of the card-based payment system lies in competition's incentives to develop better, more accurate, cheaper, and faster processes and its ability to harness reputation and learn from experience. Neither characteristic is a feature of the public legal system. We therefore contend that expanding those characteristics would likely lead to better dispute resolution processes for disputes currently in the public legal system.

How can this type of dispute resolution system be expanded beyond the card context? Wherever repeat players analogous to the associations and proprietary networks exist in a competitive environment, there is potential for extending these systems. Ironically, some of the easiest may be in

341 Daniel Klerman and Paul Mahoney provide a concise definition of independence: "A fully independent judiciary is one in which judges enjoy tenure during good behavior, a salary sufficient to shield them from pressure from either government or private parties, sufficient prestige that the hope of promotion to a more prominent post is not a large motivator, a system of prerequisites (location and appointments of offices, etc.) that is hard for the government to manipulate, and rules regarding jurisdiction over cases that are resistant to executive and legislative meddling, among others." Daniel M. Klerman and Paul G. Mahoney, The Value of Judicial Independence: Evidence from $18^{\text {th }}$ Century England, Am. L \& Econ Rev. (forthcoming) (available at http://ssm.com/abstract=587383).

342 Hadfield, supra note 11 , at 994.

343 See Gibbons, supra note 5050, at 3 ("American Express $®$, Visa, MasterCard $®$, Discover $®$, $\mathrm{JCB} B$, and other credit card issuers are arbitraging the risk [of e-commerce] by being the dispute resolution mechanism of last resort for most B2C e-commerce transactions."). 
the context of what we traditionally view as interactions between strangers. Automobile accidents, for example, generally occur between parties who have already contracted with insurance companies. ${ }^{344}$ Treaties between insurance companies could institute dispute resolution processes with characteristics like those of the card-based payment systems. Medical insurance, if it could be freed from the employer linkage created by the tax deductibility of insurance premiums, offers another potential vehicle for extending the model.

For these reasons, we advocate radically rethinking assumptions surrounding dispute resolution.

344 Today, when a car hits a pedestrian, both parties may not be insured. If, however, systems of dispute resolution develop (as described in this section), a strong incentive for pedestrians to insure themselves may develop, so that pedestrians too, would be able to reap the benefits of such a radical efficiency orientation. 